\title{
Sequential Silylcarbocyclization/Silicon-Based Cross-Coupling Reactions
}

\author{
Scott E. Denmark* and Jack Hung-Chang Liu \\ Roger Adams Laboratory, Department of Chemistry, University of Illinois, \\ 600 South Mathews Avenue, Urbana, Illinois 61801
}

\section{SUPPORTING INFORMATION}

Table of Contents

Page

General Experimental

Literature Preparations

S3

Silylcarbocyclizations of Enynes 1-5

Survey of Palladium Catalysts for the Cross-Coupling $\quad S 16$

Cross-Coupling of 6-11 with Aryl Iodides $\quad$ S19

Results of NOE Experiments $\quad S 53$

$\begin{array}{ll}\text { Procedure of the VT NMR Experiments } & S 59\end{array}$

$\begin{array}{lr}\text { References } & \text { S59 }\end{array}$

\section{General Experimental}

All reactions were performed in oven-dried $\left(150^{\circ} \mathrm{C}\right)$ and/or flame-dried glassware under an atmosphere of dry argon unless otherwise specified. Commercial reagents were purified by distillation or recrystallization prior to use. All syringes were glass. Reaction solvents tetrahydrofuran (Fisher, HPLC grade), diethyl ether (Fisher, BHT stabilized ACS grade), and methylene chloride (Fisher, unstabilized HPLC grade) were dried by percolation through two columns packed with neutral alumina under a positive pressure of argon. Reaction solvents hexane (Fisher, OPTIMA grade), and toluene (Fisher, ACS grade) were dried by percolation through a column packed with neutral alumina and a column packed with Q5 reactant, a supported copper catalyst for scavenging oxygen, under a positive pressure of argon. All reaction temperatures correspond to internal temperatures measured by Teflon-coated thermocouples unless otherwise noted. A 1.0 M solution of tetrabutylammonium fluoride in THF was prepared from solid tetrabutylammonium fluoride trihydrate $\left(\mathrm{TBAF} \bullet 3 \mathrm{H}_{2} \mathrm{O}\right.$, Fluka, Acros) and THF in a volumetric flask and was stored in a Schlenk flask. $\mathrm{Rh}_{4}(\mathrm{CO})_{12}$ and $\mathrm{Rh}(\mathrm{acac})(\mathrm{CO})_{2}$ were obtained 
from Strem Chemicals, Inc., and were used as received.

All reactions using carbon monoxide were performed in a well-ventilated hood. Because of the toxic nature of $\mathrm{CO}$, all the procedures involving the used of $\mathrm{CO}$ employed a dedicated manifold for filling the apparatus with $\mathrm{CO}$ and maintaining an atmosphere. Reactions using the pressure bomb were also conducted in the hood. The bomb was filled directly from the CO tank and vented slowly into the hood with the doors closed. All practices were in accordance with Prudent Practices in the Laboratory: Handeling and Disposal of Chemicals, National Reseach Council: Washington, DC, 1995. A CO monitor (Nighthawk KN-COPP-3) was used as a safety precaution.

"Brine" refers to a saturated solution of $\mathrm{NaCl}$. Bulb-to-bulb distillations were performed on a Büchi GKR-50 Kugelrohr and boiling points (bp) correspond to the uncorrected recorded air bath temperatures (ABT). Melting points (mp) were determined in sealed tubes using a Thomas Unimelt Hoover capillary melting point apparatus and were corrected. Analytical thin-layer chromatography was performed on Merck silica with QF-254 indicator. Visualization was accomplished with UV light and/or $\mathrm{KMnO}_{4}, \mathrm{H}_{2} \mathrm{SO}_{4}$ solution. Diethyl ether, ethyl acetate, hexanes, dimethoxy ethane, dichloromethane, acetonitrile and methanol were of reagent grade and used as received. Column chromatography was performed using Silicycle Silia-P flash silica gel or Aldrich 150-mesh aluminum oxide, activated, neutral, Brockmann I.

Analytical high pressure liquid chromatography (HPLC) was performed on a HewlettPackard 1090 Series II liquid chromatograph equipped with an Agilent Zorbax 300SB-C8 column or an Agilent Zorbax Rx-C8 column. Compounds were detected using a UV detection unit with a wavelength of $254 \mathrm{~nm}$. Response factors were generated by mixing 1:1 molar ratios of compound to naphthalene internal standard in HPLC grade acetonitrile. Retention times $\left(t_{R}\right)$ and integrated ratios were obtained using SRI Peaksimple software.

${ }^{1} \mathrm{H}$ NMR spectra were recorded on a Varian Inova $\left(500 \mathrm{MHz},{ }^{1} \mathrm{H}\right)$, Varian Unity-500 $\left(500 \mathrm{MHz},{ }^{1} \mathrm{H}, 126 \mathrm{MHz},{ }^{13} \mathrm{C}\right)$, Varian $500 \mathrm{VXR}\left(500 \mathrm{MHz},{ }^{1} \mathrm{H}, 126 \mathrm{MHz},{ }^{13} \mathrm{C}\right)$ spectrometer in chloroform- $d$ or benzene- $d_{6}$ using chloroform $\left(7.27 \mathrm{ppm},{ }^{1} \mathrm{H}, 77.23 \mathrm{ppm},{ }^{13} \mathrm{C}\right)$ or benzene (7.15 ppm, ${ }^{1} \mathrm{H}, 128.06 \mathrm{ppm},{ }^{13} \mathrm{C}$ ) as an internal reference for ${ }^{1} \mathrm{H}$. Chemical shifts are reported in

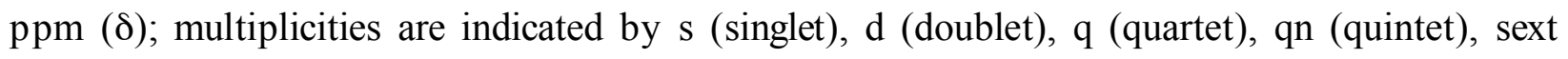
(sextet), m (multiplet), and br (broad). Coupling constants, $J$, are reported in Hertz (Hz); 
integration is provided and assignments are indicated. All ${ }^{13} \mathrm{C} N M R$ and most ${ }^{1} \mathrm{H}$ NMR assignments are corroborated by 2-D experiments (HETCOR and COSY). Spectra available on request from denmark@scs.uiuc.edu.

Infrared (IR) spectra were as thin films (neat) in $\mathrm{NaCl}$ cells, using a Perkin Elmer Spectrum BX spectrophotometer, and peaks are reported in $\mathrm{cm}^{-1}$ along with relative signal intensities: s (strong); m (medium); w (weak).

Low-resolution and high-resolution electron impact mass spectrometry (EI) was performed at $70 \mathrm{eV}$, on a Micromass 70-VSE spectrometer; low-resolution and high-resolution chemical ionization mass spectra (CI) were obtained using methane as the carrier gas, on a Micromass 70-VSE spectrometer. Data are reported in the form of $\mathrm{m} / \mathrm{z}$ (intensity relative to base peak $=100.0)$.

Microanalysis $(\mathrm{CHN})$ was performed on an Exeter CE440 analyzer. All results are reported as $\%$ by weight.

\section{Literature Preparations}

Bis(dibenzylidene)palladium chloroform adduct, ${ }^{1}$ 4,4-bis(carboethoxy)-6-hepten-1-yne (1), ${ }^{2} \mathrm{~N}$-benzyallylpropargylamine (2), ${ }^{2}$ allyl propargyl ether (3), ${ }^{2}$ 5,5-bis(carboethoxy)-7-octen1-yne (4), ${ }^{2}$ diethyl propargylmalonate, ${ }^{3}$ and methyl 3-bromocrotonate ${ }^{4}$ were prepared according literature procedures.

Silylcarbocyclization Reaction of 4,4-Bis(carboethoxy)-6-hepten-1-yne (1) with Benzyldimethylsilane. Preparation of (Z)-3-Benzyldimethylsilylmethylene-4methylcyclopentane-1,1-dicarboxylate (6).

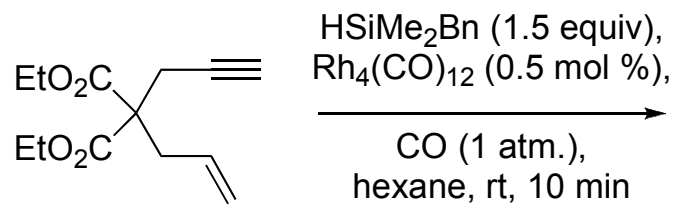

1

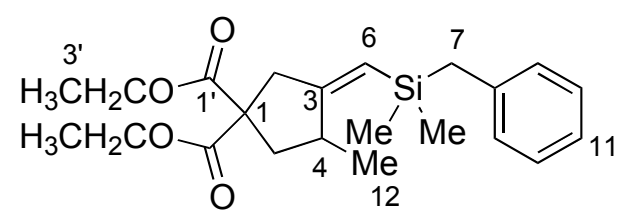

6

4,4-Bis(carboethoxy)-6-hepten-1-yne (1) (2.009 g, $8.39 \mathrm{mmol}, 1.0$ equiv) and benzyldimethylsilane (1.7 mL, $10.7 \mathrm{mmol}, 1.0$ equiv) were dissolved in hexane $(12 \mathrm{~mL})$, in an oven-dried, 50-mL, round-bottomed flask with a magnetic stirrer and a gas inlet adaptor. In 
another oven-dried, 50-mL, round-bottomed flask equipped with a magnetic stirrer and a gas inlet adaptor, a red-orange solution of $\mathrm{Rh}_{4}(\mathrm{CO})_{12}(31 \mathrm{mg}, 0.04 \mathrm{mmol}, 0.5 \mathrm{~mol} \%)$ and benzyldimethylsilane $(0.3 \mathrm{~mL}, 1.89 \mathrm{mmol}, 0.5$ equiv) in hexane $(8 \mathrm{~mL})$ was prepared. Both flasks were purged with $\mathrm{CO}$. The solution containing $\mathrm{Rh}_{4}(\mathrm{CO})_{12}$ was stirred at room temperature under $\mathrm{CO}$ for $3 \mathrm{~min}$, and this solution was added to the solution containing 4,4-bis(carboethoxy)6-hepten-1-yne (1) via cannulation under CO. Upon the mixing of the two solutions, the color quickly changed from orange to yellow, and the reaction was noticeably exothermic. After 10 min of stirring under a $\mathrm{CO}$ atmosphere at room temperature, the reaction mixture was concentrated under reduced pressure, and the residue was dissolved in EtOH $(5 \mathrm{~mL})$. To this solution was added $0.1 \mathrm{~g}$ of decolorizing charcoal and stirred for $5 \mathrm{~min}$ to remove the rhodiumcontaining species. This suspension was subsequently filtered through a pad of Celite (approximately $3 \mathrm{~cm}$ ) and was washed with more EtOH $(70 \mathrm{~mL})$. The yellow filtrated was concentrated under reduced pressure, and the resulting crude product was purified using flash chromatography (silica gel (200 g), hexane/ $\mathrm{CH}_{2} \mathrm{Cl}_{2}, 40 / 1$ (500 mL), 20/1 (1 L), 10/1 (1 L)) and diffusion pump distillation to afford $2.724 \mathrm{~g}(84 \%)$ of 6 as a colorless, viscous liquid.

Data for 6:

b.p.: $\quad 125^{\circ} \mathrm{C}(\mathrm{ABT})$ at $1.0 \times 10^{-4} \mathrm{mmHg}$

${ }^{1} \mathrm{H}$ NMR: $\quad\left(500 \mathrm{MHz}, \mathrm{CDCl}_{3}\right)$

7.21 (t, $2 \mathrm{H}, J=7.6,2 \times \mathrm{HC}(10)), 7.06$ (t, $1 \mathrm{H}, J=7.3, \mathrm{HC}(11)), 6.99$ (d, $2 \mathrm{H}, J=$ 7.0, $2 \times \mathrm{HC}(9)), 5.31(\mathrm{dd}, 1 \mathrm{H}, J=1.1,1.1, \mathrm{HC}(6)), 4.19$ (qd, $2 \mathrm{H}, J=7.1,2.2$, $\left.\mathrm{H}_{2} \mathrm{C}\left(2^{\prime}\right)\right), 4.17$ (qd, $\left.2 \mathrm{H}, J=7.1,0.6, \mathrm{H}_{2} \mathrm{C}\left(2^{\prime}\right)\right), 3.25$ (dt, $1 \mathrm{H}, J=17.2,2.0$, HC(2)), 2.76 (d, $1 \mathrm{H}, J=16.4, \mathrm{HC}(2))$, 2.67-2.62 (m, $1 \mathrm{H}, \mathrm{HC}(4)), 2.64$ (qd, $1 \mathrm{H}$, $J=8.0,1.0, \mathrm{HC}(5)), 2.12$ (d, $\left.2 \mathrm{H}, J=2.1, \mathrm{H}_{2} \mathrm{C}(7)\right), 1.89$ (dd, $1 \mathrm{H}, J=12.6,3.8$, $\mathrm{HC}(5)), 1.25$ (t, $\left.3 \mathrm{H}, J=7.2, \mathrm{H}_{3} \mathrm{C}\left(3^{\prime}\right)\right), 1.23$ (t, $\left.3 \mathrm{H}, J=7.2, \mathrm{H}_{3} \mathrm{C}\left(3^{\prime}\right)\right), 1.03$ (d, 3 $\left.\mathrm{H}, J=6.8, \mathrm{H}_{3} \mathrm{C}(12)\right), 0.07$ (s, $3 \mathrm{H}, \mathrm{H}_{3} \mathrm{CSi}$ ), 0.06 (s, $3 \mathrm{H}, \mathrm{H}_{3} \mathrm{CSi}$ ).

${ }^{13} \mathrm{C}$ NMR: $\quad\left(126 \mathrm{MHz}, \mathrm{CDCl}_{3}\right)$

$172.4\left(\mathrm{C}\left(1^{\prime}\right)\right), 172.1\left(\mathrm{C}\left(1^{\prime}\right)\right), 164.3(\mathrm{C}(3)), 140.3(\mathrm{C}(8)), 128.5$ (C(10)), 128.3 (C(9)), 124.2 (C(11)), $118.9(\mathrm{C}(6)), 61.7\left(\mathrm{C}\left(2^{\prime}\right)\right), 61.6\left(\mathrm{C}\left(2^{\prime}\right)\right), 58.6(\mathrm{C}(1)), 44.6$ (C(2)), $42.0(\mathrm{C}(5)), 37.0(\mathrm{C}(4)), 27.0(\mathrm{C}(7)), 22.7$ (C(12)), 14.2 (C(3')), 14.2 $\left(\mathrm{C}\left(3^{\prime}\right)\right),-1.6(\mathrm{CSi}),-1.7(\mathrm{CSi})$. 
IR: (neat)

3463 (s), 2979 (m), 1373 (s), 1629 (m), 1493 (m), 1451 (m), 1366 (m), 1246 (s), $1159(\mathrm{~m}), 1096(\mathrm{~m}), 837$ (m), 761 (m).

LRMS: (CI):

55 (3.4), 57 (5.3), 59 (3.0), 62 (25.8), 63 (100.0), 71 (2.2), 107 (2.0), 389 (2.7, $\left.[\mathrm{M}+\mathrm{H}]^{+}\right)$.

HRMS: $\left(\mathrm{CI},[\mathrm{M}+\mathrm{H}]^{+}\right)$:

calcd.: 389.214813

found: 389.214541

Analysis: $\mathrm{C}_{22} \mathrm{H}_{37} \mathrm{O}_{4} \mathrm{Si} \quad(388.57)$

calcd.: C, 68.00; $\quad$ H, 8.30.

found: C, 67.99; $\quad \mathrm{H}, 8.20$.

$\underline{\mathrm{R}_{\mathrm{f}}}: \quad 0.78$ (silica gel, hexane/EtOAc, 5/1, UV)

$\underline{t_{\mathrm{R}}}: 9.866 \min$ (Agilent Zorbax 300SB-C8, 60\% (MeCN in $\mathrm{H}_{2} \mathrm{O}$ ) to $100 \% \mathrm{ramp}$ at $4 \% / \mathrm{min}, 100 \%$ for $2 \mathrm{~min}, 100 \%$ to $60 \%$ gradient at $11.4 \% / \mathrm{min}$ )

\section{Silylcarbocyclization Reaction of $N$-Benzyallylpropargylamine (2) with Benzyldimethylsilane. Preparation of $N$-Benzyl-(Z)-3-benzyldimethylsilylmethylene-4- methylpyrrolidine (7).}

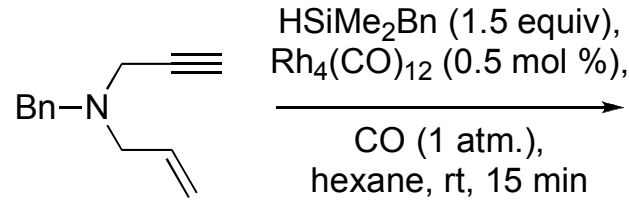

2

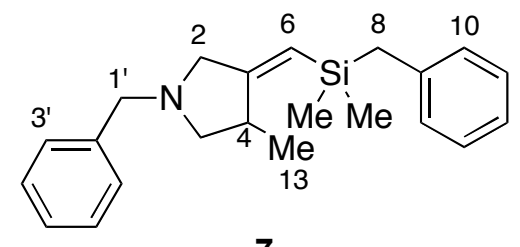

7

$N$-Benzyallylpropargylamine (2) $\quad\left(\begin{array}{llllll}1.112 & \mathrm{~g}, & 6.00 & \mathrm{mmol}, & 1.0 & \text { equiv }) \text { and }\end{array}\right.$ benzyldimethylsilane $(1.0 \mathrm{~mL}, 6.00 \mathrm{mmol}, 1.0$ equiv) were dissolved in hexane $(9 \mathrm{~mL})$, in a flame-dried, 25-mL, round-bottomed flask with a magnetic stirrer and a gas inlet adaptor. In another flame-dried, 50-mL, round-bottomed flask equipped with a gas inlet adaptor, a redorange solution of $\mathrm{Rh}_{4}(\mathrm{CO})_{12}(22 \mathrm{mg}, 0.03 \mathrm{mmol}, 0.5 \mathrm{~mol} \%)$ and benzyldimethylsilane $(0.5 \mathrm{~mL}$, $3.00 \mathrm{mmol}, 0.5$ equiv) in hexane $(6 \mathrm{~mL})$ was prepared. Both flasks were purged with $\mathrm{CO}$. The solution containing $\mathrm{Rh}_{4}(\mathrm{CO})_{12}$ was stirred at room temperature under $\mathrm{CO}$ for $3 \mathrm{~min}$, and this solution was added to the solution containing $N$-benzyallylpropargylamine (2) via cannulation 
under CO. Upon the mixing of the two solutions, the color quickly changed from red-orange to yellow, and the reaction was noticeably exothermic. After $15 \mathrm{~min}$ of stirring under a $\mathrm{CO}$ atmosphere at room temperature, the reaction was quenched by adding a solution of thiourea (50 $\mathrm{mg}, 0.60 \mathrm{mmol}, 10 \mathrm{~mol} \%)$ in EtOH $(15 \mathrm{~mL})$. This mixture was stirred at room temperature under air for approximately $50 \mathrm{~min}$, during which time the reaction mixture turned into a yellow suspension. It was then filtered through a layer of silica gel (approximately $3 \mathrm{~cm}$ ), and the silica gel was washed with $60 \mathrm{~mL}$ of EtOAc. The yellow filtrate was concentrated under reduced pressure. The resulting crude product was purified using flash chromatography (neutral alumina activity I (300 g), hexane/EtOAc, 8/1 (500 mL), 6/1 (500 mL)), reverse phase chromatography (reverse phase silica gel (250 g), $\mathrm{MeCN})$, and diffusion pump distillation to afford $1.914 \mathrm{~g} \mathrm{(95 \% )}$ of 7 as a colorless, viscous liquid.

Data for 7:

b.p.: $177^{\circ} \mathrm{C}(\mathrm{ABT})$ at $5.5 \times 10^{-5} \mathrm{mmHg}$

${ }^{1} \mathrm{H}$ NMR: $\quad\left(500 \mathrm{MHz}, \mathrm{C}_{6} \mathrm{D}_{6}\right)$

7.34 (d, $\left.2 \mathrm{H}, J=7.6,2 \times \mathrm{HC}\left(3^{\prime}\right)\right), 7.19$ (t, $\left.2 \mathrm{H}, J=7.6,2 \times \mathrm{HC}\left(4^{\prime}\right)\right), 7.14$ (t, $2 \mathrm{H}, J$ = 7.6, $2 \times \mathrm{HC}(11)), 7.09$ (d, $\left.1 \mathrm{H}, J=7.3, \mathrm{HC}\left(5^{\prime}\right)\right), 7.00$ (t, $\left.1 \mathrm{H}, J=7.3, \mathrm{HC}(12)\right)$, 6.97 (d, $2 \mathrm{H}, J=8.1,2 \times \mathrm{HC}(10)), 5.20$ (d, $1 \mathrm{H}, J=1.5, \mathrm{HC}(6)), 3.46$ (d, $1 \mathrm{H}, J=$ 12.9, $\left.\mathrm{HC}\left(1^{\prime}\right)\right), 3.37$ (dd, $\left.1 \mathrm{H}, J=13.9,2.4, \mathrm{HC}\left(1^{\prime}\right)\right), 3.36$ (d, $1 \mathrm{H}, J=24.4$, $\mathrm{HC}(2)), 2.84$ (dd, $1 \mathrm{H}, J=13.9,1.5, \mathrm{HC}(2)), 2.55-2.52$ (m, $1 \mathrm{H}, \mathrm{HC}(4))$, 2.43-2.37 (m, $\left.2 \mathrm{H}, \mathrm{H}_{2} \mathrm{C}(5)\right), 2.09$ (d, $\left.1 \mathrm{H}, J=13.6, \mathrm{HC}(8)\right), 1.11$ (d, $3 \mathrm{H}, J=7.1, \mathrm{H}_{3} \mathrm{C}(13)$ ), 0.09 (s, $3 \mathrm{H}, \mathrm{H}_{3} \mathrm{CSi}$ ), 0.08 (s, $3 \mathrm{H}, \mathrm{H}_{3} \mathrm{CSi}$ ).

${ }^{13} \mathrm{C}$ NMR: $\quad\left(126 \mathrm{MHz}, \mathrm{C}_{6} \mathrm{D}_{6}\right)$

165.5 (C(3)), 140.7 (C(2’)), 140.2 (C(9)), 129.2 (C(3’)), 129.0 (C(3’)), 128.9 (C(aryl)), 128.8 (C(aryl)), 128.6 (C(aryl)), 128.4 (C(aryl)), 127.6 (C(5')), 124.8 (C(12)), 116.2 (C(6)), 63.1 (C(2)), 62.9 (C(1')), 60.9 (C(5)), 38.2 (C(4)), 27.4 (C(8)), $22.3(\mathrm{C}(13)),-1.4(\mathrm{CSi}),-1.6(\mathrm{CSi})$.

IR: (neat)

3025 (m), 2958 (s), 2925 (s), 2785 (s), 1632 (s), 1600 (s), 1493 (s), 1452 (s), 1340 (m), 1248 (s), 1207 (s), 1153 (s), 1056 (m), 1028 (s), 835 (s), 760 (m), 698 (m).

LRMS: (CI):

$336\left(100.0,[\mathrm{M}+\mathrm{H}]^{+}\right), 320$ (20.0), 244 (24.2), 186 (29.1), 149 (34.0), 91 (20.7), 75 
(12.2)

HRMS: $\left(\mathrm{CI},[\mathrm{M}+\mathrm{H}]^{+}\right)$:

calcd.: 336.214754

found: 336.214403

Analysis: $\mathrm{C}_{22} \mathrm{H}_{37} \mathrm{O}_{4} \mathrm{Si} \quad(335.56)$

calcd.: C, 78.75; H, 8.71; $\quad \mathrm{N}, 4.17$.

found: C, 78.55; $\quad \mathrm{H}, 8.56 ; \quad \mathrm{N}, 4.44$.

$\underline{\mathrm{R}}_{\mathrm{f}}: \quad 0.57$ (silica gel, hexane/EtOAc, 5/1, UV)

$\underline{t_{\mathrm{R}}}: \quad 20.71 \mathrm{~min}\left(\mathrm{HP}-5,150{ }^{\circ} \mathrm{C}\right.$ to $270{ }^{\circ} \mathrm{C}$ ramp at $10{ }^{\circ} \mathrm{C} / \mathrm{min}, 270{ }^{\circ} \mathrm{C}$ for $\left.15 \mathrm{~min}\right)$

\section{Silylcarbocyclization Reaction of Allyl Propargyl Ether (3) with Benzyldimethylsilane. Preparation of $(Z)-3$-Benzyldimethylsilylmethylene-4-methyltetrahydrofuran (8).}

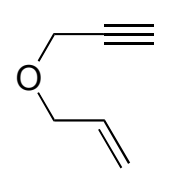

3

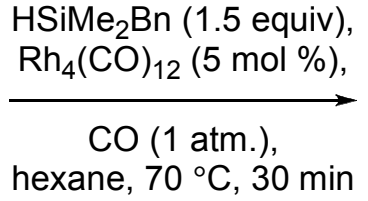

hexane, $70^{\circ} \mathrm{C}, 30 \mathrm{~min}$

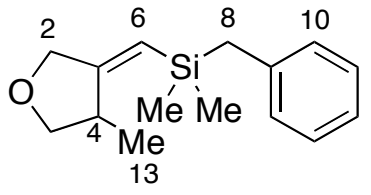

8

Allyl propargyl ether (3) (384 mg, $4.00 \mathrm{mmol}, 1.0$ equiv) was dissolved in toluene (4 $\mathrm{mL}$ ), in a flame-dried, $10-\mathrm{mL}$, round-bottomed flask with a magnetic stirrer and a gas inlet adaptor. In another flame-dried, 50-mL, round-bottomed flask equipped with a magnetic stirrer and a gas inlet adaptor, a light green solution of $\mathrm{Rh}(\mathrm{acac})(\mathrm{CO})_{2}(52 \mathrm{mg}, 0.20 \mathrm{mmol}, 5 \mathrm{~mol} \%)$ and benzyldimethylsilane $(1.3 \mathrm{~mL}, 8.00 \mathrm{mmol}, 2.0$ equiv) in hexane $(16 \mathrm{~mL})$ was prepared. Both flasks were purged with $\mathrm{CO}$. The solution containing $\mathrm{Rh}(\mathrm{acac})(\mathrm{CO})_{2}$ was placed in an oil bath preheated to $70{ }^{\circ} \mathrm{C}$, and this solution was stirred in the oil bath for $3 \mathrm{~min}$. Then, the solution containing allyl propargyl ether (3) was added to the solution containing $\mathrm{Rh}_{4}(\mathrm{CO})_{12}$ via cannulation under $\mathrm{CO}$. Upon the mixing of the two solutions, the color changed from light-green to yellow. After 30 min of stirring under a $\mathrm{CO}$ atmosphere in the oil bath, the reaction was quenched by adding a solution of thiourea (78 mg, $1.00 \mathrm{mmol}, 2.5 \mathrm{~mol} \%)$ in EtOH (5 mL). This mixture immediately turned red, and the color quickly faded to red-orange and then to yelloworange. It was stirred at room temperature under air for approximately $20 \mathrm{~min}$, during which time the reaction mixture turned into a yellow suspension. The suspension was then filtered through a layer of silica gel, and the silica gel was washed with $100 \mathrm{~mL}$ of EtOAc. The bright-yellow 
filtrate was concentrated under reduced pressure. The resulting crude product was purified using flash chromatography (silica gel (100 g), hexane/Et $\left.{ }_{2} \mathrm{O}, 60 / 1\right)$ and Kugelrhor distillation to afford $520 \mathrm{mg}(53 \%)$ of $\mathbf{8}$ as a colorless, viscous liquid.

\section{Data for 8:}

b.p.: $\quad 190{ }^{\circ} \mathrm{C}(\mathrm{ABT})$ at $0.2 \mathrm{mmHg}$

${ }^{1} \mathrm{H}$ NMR: $\quad\left(500 \mathrm{MHz}, \mathrm{CDCl}_{3}\right)$

7.22 (t, $2 \mathrm{H}, J=7.7,2 \times \mathrm{HC}(11), 7.08$ (t, $1 \mathrm{H}, J=7.3, \mathrm{HC}(12)), 7.01$ (d, $2 \mathrm{H}, J=$ 7.6, $2 \times \mathrm{HC}(10)), 5.29$ (d, $1 \mathrm{H}, J=1.5, \mathrm{HC}(6)), 4.44$ (dt, $1 \mathrm{H}, J=13.7,1.7$, $\mathrm{HC}(2)), 4.15$ (dd, $1 \mathrm{H}, J=13.7,1.7, \mathrm{HC}(2)), 3.82$ (dd, $1 \mathrm{H}, J=8.3,5.4, \mathrm{HC}(5)$ ), 3.67 (dd, $1 \mathrm{H}, J=8.3,1.0, \mathrm{HC}(5))$, 2.63-2.60 (m, $1 \mathrm{H}, \mathrm{HC}(4)$ ), 2.17 (s, $2 \mathrm{H}$, $\left.\mathrm{H}_{2} \mathrm{C}(8)\right), 1.08$ (d, $\left.3 \mathrm{H}, J=7.1, \mathrm{H}_{3} \mathrm{C}(13)\right), 0.14$ (s, $3 \mathrm{H}, \mathrm{H}_{3} \mathrm{CSi}$ ), 0.13 (s, $3 \mathrm{H}$, $\mathrm{H}_{3} \mathrm{CSi}$.

${ }^{13} \mathrm{C}$ NMR: $\quad\left(126 \mathrm{MHz}, \mathrm{CDCl}_{3}\right)$

$163.5(\mathrm{C}(3)), 140.1(\mathrm{C}(9)), 128.4(\mathrm{C}(11)), 124.2$ (C(12)), $115.0(\mathrm{C}(6)), 76.2$ (C(5)), $73.4(\mathrm{C}(2)), 38.3(\mathrm{C}(4)), 27.0(\mathrm{C}(8)), 20.7$ (C(13)), -1.7 (CSi), -1.9 (CSi).

IR: (neat)

$2963(\mathrm{~m}), 2850(\mathrm{w}), 1636(\mathrm{w}), 1600(\mathrm{w}), 1493$ (m), $1348(\mathrm{~m}), 1248(\mathrm{~m}), 1087$ (m), $922(\mathrm{w}), 837(\mathrm{~s}), 699(\mathrm{~s})$.

LRMS: (EI):

246 (14.2, [M] $\left.{ }^{+}\right), 155$ (100.0), 125 (26.6), 113 (17.9), 91 (20.7), 75 (49.3), 59 (36.2).

HRMS: (EI, $\left.[\mathrm{M}]^{+}\right)$:

calcd.: 246.14085

found: 246.14369

Analysis: $\mathrm{C}_{22} \mathrm{H}_{37} \mathrm{O}_{4} \mathrm{Si} \quad$ (246.42)

calcd.: C, 73.11; $\quad$ H, 9.00.

found: $\mathrm{C}, 73.18 ; \quad \mathrm{H}, 8.95$.

距: $\quad 0.67$ (silica gel, hexane/EtOAc, 5/1, UV)

$t_{\underline{R}}: \quad 3.19 \mathrm{~min}$ (Agilent Zorbax Rx-C8, 100\% MeCN (1 mL/min)) 
Silylcarbocyclization Reaction of 5,5-Bis(carboethoxy)-7-octen-1-yne (4) with Benzyldimethylsilane. Preparation of Diethyl (Z)-3-Benzyldimethylsilylmethylmethylene-4methylcyclopentane-1,1-dicarboxylate (9).

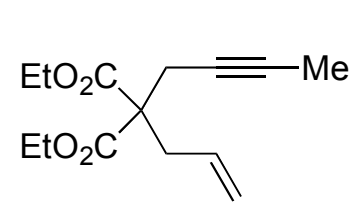

4

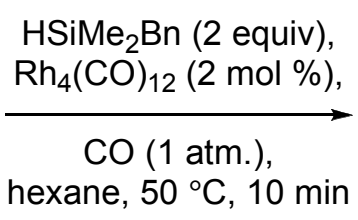

hexane, $50^{\circ} \mathrm{C}, 10 \mathrm{~min}$

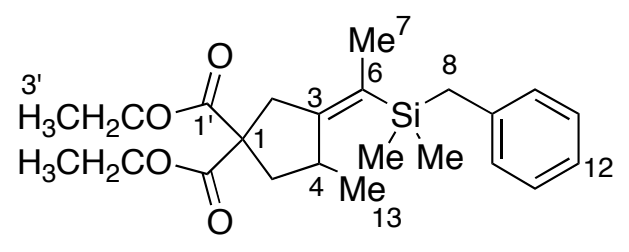

9

5,5-Bis(carboethoxy)-7-octen-1-yne (4) (1.262 g, $5.00 \mathrm{mmol}, 1.0$ equiv) was dissolved in hexane $(5 \mathrm{~mL})$, which was saturated with $\mathrm{CO}$ by bubbling for approximately $20 \mathrm{~min}$, in a flamedried, 25-mL, round-bottomed flask with a magnetic stirrer and a gas inlet adaptor. In another flame-dried, 100-mL, round-bottomed flask equipped with a magnetic stirrer a gas inlet adaptor, a red-orange solution of $\mathrm{Rh}_{4}(\mathrm{CO})_{12}(75 \mathrm{mg}, 0.10 \mathrm{mmol}, 2 \mathrm{~mol} \%)$ and benzyldimethylsilane (1.60 mL, $10.00 \mathrm{mmol}, 2.0$ equiv) in hexane $(20 \mathrm{~mL})$ was prepared. Both flasks were purged with $\mathrm{CO}$. The solution containing $\mathrm{Rh}_{4}(\mathrm{CO})_{12}$ heated to $50{ }^{\circ} \mathrm{C}$ by placing in an oil bath, and it was stirred at room temperature under $\mathrm{CO}$ for $3 \mathrm{~min}$. The color of the solution containing $\mathrm{Rh}_{4}(\mathrm{CO})_{12}$ darkened somewhat upon heating. Then, this solution was added to the solution containing 5,5bis(carboethoxy)-7-octen-1-yne (4) via cannulation under CO. Upon the mixing of the two solutions, the color turned from red-brown to yellow-brown. After $10 \mathrm{~min}$ of stirring under a $\mathrm{CO}$ atmosphere at $50{ }^{\circ} \mathrm{C}$, the reaction mixture was allowed to cool down, and the reaction mixture was treated with a solution of thiourea $(76.8 \mathrm{mg}, 1.00 \mathrm{mmol}, 20 \mathrm{~mol} \%)$ in EtOH $(5 \mathrm{~mL})$. This mixture was stirred at room temperature under air for $20 \mathrm{~min}$, and it quickly turned into a yellowbrown suspension. This mixture was then filtered through a layer of silica gel, and the yellow filtrate was concentrated under reduced pressure. The resulting crude product was purified using flash chromatography (silica gel (200 g), hexane/EtOAc, 80/1 (500 mL), 60/1 (500 mL), 40/1 (1 L), 30/1 (500 mL), 20/1 (500 mL), 10/1 (500 mL)) and diffusion pump distillation to afford $1.637 \mathrm{~g} \mathrm{(81 \% )} \mathrm{of} 9$ as a colorless, viscous liquid.

Data for 9:

b.p.: $\quad 160^{\circ} \mathrm{C}(\mathrm{ABT})$ at $1.0 \times 10^{-4} \mathrm{mmHg}$

H NMR: $\quad\left(500 \mathrm{MHz}, \mathrm{CDCl}_{3}\right)$

7.19 (t, $2 \mathrm{H}, J=7.7,2 \times \mathrm{HC}(11)), 7.06$ (t, $1 \mathrm{H}, J=7.3$, HC(12)), 6.97 (d, $2 \mathrm{H}, J=$ 7.0, $2 \times \mathrm{HC}(10)), 4.22\left(\mathrm{q}, 2 \mathrm{H}, J=7.2, \mathrm{H}_{2} \mathrm{C}\left(2^{\prime}\right)\right), 4.19(\mathrm{qd}, 2 \mathrm{H}, J=7.2,1.1$, 
$\left.\mathrm{H}_{2} \mathrm{C}\left(2^{\prime}\right)\right), 3.14$ (d, $\left.1 \mathrm{H}, J=17.3, \mathrm{HC}(2)\right), 2.90$ (d, $\left.1 \mathrm{H}, J=17.3, \mathrm{HC}(2)\right), 2.75-2.72$ (m, $1 \mathrm{H}, \mathrm{HC}(4)), 2.48$ (dd, $1 \mathrm{H}, J=13.4,7.8, \mathrm{HC}(5)), 2.16$ (s, $\left.2 \mathrm{H}, \mathrm{H}_{2} \mathrm{C}(8)\right), 2.12$ (dd, $1 \mathrm{H}, J=12.4,2.4, \mathrm{HC}(5)), 1.63$ (s, $\left.3 \mathrm{H}, \mathrm{H}_{3} \mathrm{C}(7)\right), 1.28$ (t, $3 \mathrm{H}, J=7.2$, $\left.\mathrm{H}_{3} \mathrm{C}\left(3^{\prime}\right)\right), 1.25$ (t, $\left.3 \mathrm{H}, J=7.1, \mathrm{H}_{3} \mathrm{C}\left(3^{\prime}\right)\right), 0.89$ (s, $3 \mathrm{H}, J=7.1, \mathrm{H}_{3} \mathrm{C}(13)$ ), 0.02 (s, 3 $\mathrm{H}, \mathrm{H}_{3} \mathrm{CSi}$ ), 0.01 (s, $3 \mathrm{H}, \mathrm{H}_{3} \mathrm{CSi}$ ).

${ }^{13} \mathrm{C}$ NMR: $\quad\left(126 \mathrm{MHz}, \mathrm{CDCl}_{3}\right)$

$173.0\left(\mathrm{C}\left(1^{\prime}\right)\right), 172.6$ (C(1')), 156.9 (C(3)), 140.4 (C(6)), 128.4 (C(10)), 128.3 (C(11)), 124.1 (C(12)), 123.9 (C(9)), 61.7 (C(2’)), 61.7 (C(2’)), 58.5 (C(1)), 41.3 (C(2)), 38.6 (C(5)), 37.8 (C(4)), 26.2 (C(8)), 23.2 (C(13)), 23.2 (C(7)), 14.3 $\left(\mathrm{C}\left(3^{\prime}\right)\right), 14.3\left(\mathrm{C}\left(3^{\prime}\right)\right),-1.6(\mathrm{CSi}),-1.6(\mathrm{CSi})$.

$\underline{\text { IR: }}$ (neat)

2978 (s), 1732 (s), 1624 (m), 1600 (m), 1494 (s), 1452 (s), 1367 (s), 1298 (s), 1248 (s), 1811 (s), 1110 (s), 1096 (s), 1071 (s), 1035 (s), 831 (s), 792 (s), 761 (s), $699(\mathrm{~s})$.

LRMS: (CI):

$403\left(73.8,[\mathrm{M}+\mathrm{H}]^{+}\right), 387$ (17.7), 311 (100.0), 239 (25.1), 209 (28.9), 181 (43.8), 149 (34.2), 135 (24.4), 107 (33.7).

HRMS: $\left(\mathrm{CI},[\mathrm{M}+\mathrm{H}]^{+}\right)$:

calcd.: 403.230463

found: 403.230952

Analysis: $\mathrm{C}_{23} \mathrm{H}_{34} \mathrm{O}_{4} \mathrm{Si} \quad(402.60)$

calcd.: C, 68.62; $\quad \mathrm{H}, 8.51$.

found: C, 68.74; $\quad \mathrm{H}, 8.61$.

$\underline{\mathrm{R}}_{\mathrm{f}}: \quad 0.69$ (silica gel, hexane/EtOAc, 5/1, UV)

$\underline{t_{\mathrm{R}}}: \quad 3.13 \mathrm{~min}$ (Agilent Zorbax 300SB-C8, 100\% MeCN (1 mL/min)) 


\section{Preparation of Methyl 5,5-Bis(carboethoxy)-2-octene-7-ynoate (5).}
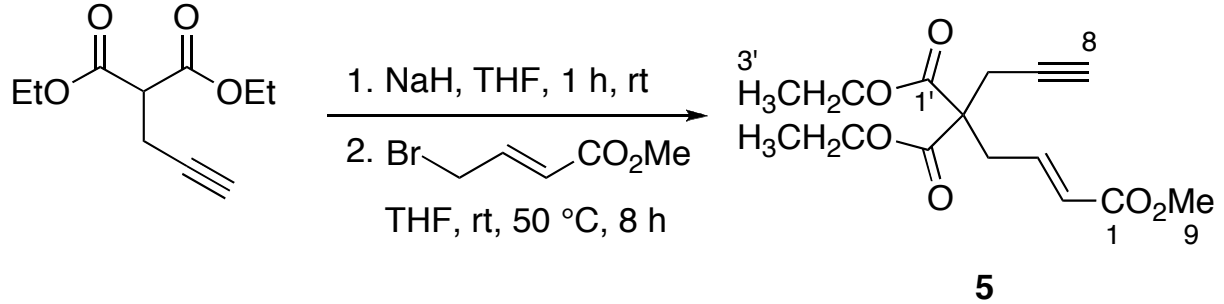

In a flamed-dried, 100-mL, round-bottomed flask equipped with a magnetic stirrer and a gas inlet adaptor, $\mathrm{NaH}$ (60\% wt in mineral oil, $529 \mathrm{mg}, 13.2 \mathrm{mmol}, 1.2$ equiv) was dispersed in THF $(25 \mathrm{~mL})$. To this suspension was added a solution of diethyl propargylmalonate $(2.180 \mathrm{~g}$, $11.0 \mathrm{mmol}, 1.0$ equiv) in THF $(10 \mathrm{~mL}$, ) in the course of $2 \mathrm{~min}$ at room temperature. Bubbling and heat evolution were observed, and the reaction mixture was stirred at room temperature under Ar. When the bubbling subsided, the reaction mixture became a slightly opaque, lightyellow solution. After $30 \mathrm{~min}$ of stirring, the reaction mixture was added a solution methyl 3bromocrotonate $(2.180 \mathrm{~g}, 13.2 \mathrm{mmol}, 1.2$ equiv) in THF $(25 \mathrm{~mL})$. The reaction mixture immediately turned into a yellow suspension, and an exotherm was observed. The reaction mixture was heated to $50{ }^{\circ} \mathrm{C}$ and was stirred under Ar for $2 \mathrm{~h}$. Then, the reaction mixture was allowed to cool down, and it was subsequently quenched with a saturated solution of $\mathrm{NH}_{4} \mathrm{Cl}(10$ $\mathrm{mL})$. Consequently, all the solid quickly dissolved, and the reaction mixture was poured into a $125-\mathrm{mL}$ separatory funnel containing $20 \mathrm{~mL}$ of water. The aqueous layer was extracted with $\mathrm{Et}_{2} \mathrm{O}(3 \times 20 \mathrm{~mL})$. The combined organic layers were washed with brine $(20 \mathrm{~mL})$, dried over anhydrous $\mathrm{MgSO}_{4}$, and filtered, and the filtrate was concentrated under reduced pressure. The resulting crude product was purified by flash chromatography (silica gel (200 g), hexane/EtOAc, 20/1 (750 mL), 10/1 (250 mL), 5/1 (750 mL)) and Kugelrhor distillation to afford $2.922 \mathrm{~g}(91 \%)$ of 5 as a colorless, viscous liquid.

\section{Data for 5:}

b.p.: $193{ }^{\circ} \mathrm{C}(\mathrm{ABT})$ at $0.2 \mathrm{mmHg}$

H NMR: $\quad\left(500 \mathrm{MHz}, \mathrm{CDCl}_{3}\right)$

$6.78(\mathrm{dt}, 1 \mathrm{H}, J=15.6,7.8, \mathrm{HC}(3)), 5.96(\mathrm{dt}, 1 \mathrm{H}, J=15.6,1.4, \mathrm{HC}(2)), 4.23$ (qd, $\left.4 \mathrm{H}, J=7.1,0.7,2 \times \mathrm{H}_{2} \mathrm{C}\left(2^{\prime}\right)\right), 3.73$ (s, $\left.3 \mathrm{H}, \mathrm{H}_{3}(9)\right), 2.96$ (dd, $2 \mathrm{H}, J=7.8,1.3$, $\left.\mathrm{H}_{2} \mathrm{C}(4)\right), 2.81$ (d, $\left.2 \mathrm{H}, J=2.6, \mathrm{H}_{2} \mathrm{C}(6)\right), 2.06(\mathrm{t}, 1 \mathrm{H}, J=2.7, \mathrm{HC}(8)), 1.27$ (q, $6 \mathrm{H}$, $\left.J=7.1,2 \times \mathrm{H}_{3} \mathrm{C}\left(3^{\prime}\right)\right)$. 


\section{${ }^{13} \mathrm{C}$ NMR: $\quad\left(126 \mathrm{MHz}, \mathrm{CDCl}_{3}\right)$}

169.4 (C(1')), 166.5 (C(1)), 142.4 (C(3)), 125.5 (C(2)), 78.5 (C(7)), 72.2 (C(8)), $62.2\left(\mathrm{C}\left(2^{\prime}\right)\right)$, $56.5(\mathrm{C}(5)), 51.8(\mathrm{C}(9)), 25.0(\mathrm{C}(4)), 23.2(\mathrm{C}(6)), 14.2\left(\mathrm{C}\left(3^{\prime}\right)\right)$.

IR: (neat)

3282 (m), 2984 (m), 2123 (w), 1732 (s), 1661 (m), 1438 (m), 1278 (s), 1194 (s), 1097 (m), 1071 (m), $835(\mathrm{w})$.

LRMS: (CI):

297 (71.6, $\left.[\mathrm{M}+\mathrm{H}]^{+}\right), 265$ (100.0), 251 (59.0), 237 (72.2), 223 (61.0), 191 (66.9), 177 (45.0), 163 (58.7), 151 (24.2), 119 (15.8), 91 (21.2).

HRMS: (CI, $\left.[\mathrm{M}+\mathrm{H}]^{+}\right)$:

calcd.: 297.1338

found: 297.1332

Analysis: $\mathrm{C}_{24} \mathrm{H}_{34} \mathrm{O}_{6} \mathrm{Si} \quad(296.32)$

calcd.: C, 60.80; $\quad \mathrm{H}, 6.80$.

found: $\mathrm{C}, 60.46 ; \quad \mathrm{H}, 6.78$.

$\underline{\mathrm{R}}_{\mathrm{f}}: \quad 0.24$ (silica gel, hexane/EtOAc, 5/1, UV)

$\underline{t_{\mathrm{R}}}: \quad 2.23 \mathrm{~min}(\mathrm{YMC}-\mathrm{Pac}$ Pro C18, 100\% MeCN (1 mL/min))

Silylcarbocyclization Reaction of Methyl 5,5-Bis(carboethoxy)-2-octene-7-ynoate (5) with Benzyldimethylsilane. Preparation of Diethyl (Z)-3-Benzyldimethylsilylmethylene-4methoxycarbonylmethylcyclopentane-1,1-dicarboxylate (10).

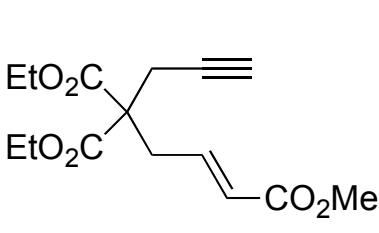

5

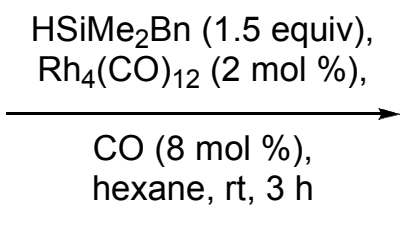

hexane, rt, $3 \mathrm{~h}$

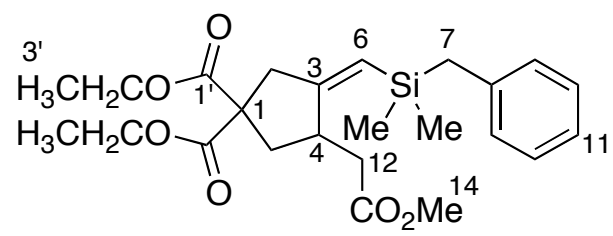

10

In an flame-dried, 25-mL, Schlenk flask with a magnetic stirrer, 5 (1.482 g, $5.00 \mathrm{mmol}$, 1.0 equiv) and benzyldimethylsilane $(0.8 \mathrm{~mL}, 5.00 \mathrm{mmol}, 1.0$ equiv) were dissolved in hexane $(15 \mathrm{~mL})$. The Schlenk flask was purged with Ar and was subsequently sealed. In another flamedried, 25-mL, round-bottomed flask equipped with a magnetic stirrer and a gas inlet adaptor, a dark red solution of $\mathrm{Rh}_{4}(\mathrm{CO})_{12}(75 \mathrm{mg}, 0.10 \mathrm{mmol}, 2 \mathrm{~mol} \%)$ and benzyldimethylsilane $(0.4 \mathrm{~mL}$, $2.5 \mathrm{mmol}, 0.5$ equiv) in hexane $(10 \mathrm{~mL})$ was prepared by stirring at room temperature under $\mathrm{Ar}$ 
for $5 \mathrm{~min}$. This solution was subsequently added into the Schlenk flask via cannulation under Ar, followed by the addition of $\mathrm{CO}(9.7 \mathrm{~mL}, 0.4 \mathrm{mmol}, 8 \mathrm{~mol} \%)$ via a gas-tight syringe. Upon the addition of the solution containing $\mathrm{Rh}_{4}(\mathrm{CO})_{12}$ the reaction mixture turned from red to yellow in approximately $5 \mathrm{~min}$. When the additions were completed, the reaction mixture was stirred at room temperature for $3 \mathrm{~h}$. When the reaction period had completed, the reaction mixture was treated with a solution of thiourea $(60 \mathrm{mg}, 0.80 \mathrm{mmol}, 16 \mathrm{~mol} \%)$ in EtOH $(5 \mathrm{~mL})$. The reaction mixture quickly turned red and then turned into a brown suspension. This mixture was stirred at room temperature under air for approximately $20 \mathrm{~min}$. This brown suspension was filtered through a layer of silica gel and it was washed with $100 \mathrm{~mL}$ of EtOH. The yellow filtrate was concentrated under reduced pressure. The resulting crude product was purified using flash chromatography (silica gel (210 g), hexane/DME, 40/1 (2.5 L), 20/1 (1.5 L)) and diffusion pump distillation to afford $866 \mathrm{mg}(87 \%)$ of $\mathbf{1 0}$ as a colorless, viscous liquid.

Data for 10:

b.p.: $180^{\circ} \mathrm{C}(\mathrm{ABT})$ at $6.0 \times 10^{-5} \mathrm{mmHg}$

${ }^{1} \mathrm{H}$ NMR: $\quad\left(500 \mathrm{MHz}, \mathrm{CDCl}_{3}\right)$

$7.21(\mathrm{t}, 2 \mathrm{H}, J=7.7,2 \times \mathrm{HC}(10)), 7.07$ (t, $1 \mathrm{H}, J=7.5$, HC(11)), 6.99 (d, $2 \mathrm{H}, J=$ 7.1, $2 \times \mathrm{HC}(9)), 5.41(\mathrm{~d}, 1 \mathrm{H}, J=1.0, \mathrm{HC}(6)), 4.20(\mathrm{dq}, 2 \mathrm{H}, J=7.2,1.9$, $\left.\mathrm{H}_{2} \mathrm{C}\left(2^{\prime}\right)\right)$ ), 4.17 (q, $\left.2 \mathrm{H}, J=7.1, \mathrm{H}_{2} \mathrm{C}\left(2^{\prime}\right)\right), 3.68$ (s, $\left.3 \mathrm{H}, \mathrm{H}_{3} \mathrm{C}(14)\right), 3.17$ (dt, $1 \mathrm{H}, J=$ 16.4, 2.0, HC(2)), 3.04-3.00 (m, $1 \mathrm{H}, \mathrm{HC}(4)), 2.81$ (d, $1 \mathrm{H}, J=16.4, \mathrm{HC}(2)), 2.67$ $(\mathrm{dd}, 1 \mathrm{H}, J=14.1,8.2, \mathrm{HC}(5)), 2.30$ (d, $1 \mathrm{H}, J=1.5, \mathrm{HC}(12)), 2.28$ (dd, $1 \mathrm{H}, J=$ 22.4, 15.8, HC(12)), 2.14 (s, $\left.2 \mathrm{H}, \mathrm{H}_{2} \mathrm{C}(7)\right), 2.07$ (dd, $\left.1 \mathrm{H}, J=14.1,4.5, \mathrm{HC}(5)\right)$, 1.26 (t, $\left.3 \mathrm{H}, J=7.1, \mathrm{H}_{3} \mathrm{C}\left(3^{\prime}\right)\right), 1.23$ (t, $\left.3 \mathrm{H}, J=7.2, \mathrm{H}_{3} \mathrm{C}\left(3^{\prime}\right)\right), 0.11$ (s, $3 \mathrm{H}$, $\left.\mathrm{H}_{3} \mathrm{CSi}\right), 0.10$ (s, $3 \mathrm{H}, \mathrm{H}_{3} \mathrm{CSi}$ ).

${ }^{13} \mathrm{C} \mathrm{NMR:} \quad\left(126 \mathrm{MHz}, \mathrm{CDCl}_{3}\right)$

172.5 (C(1')), 172.2 (C(1')), 171.1 (C(13)), 161.1 (C(3)), 140.0 (C(8)), 128.4 (C(9)), 128.3 (C(10)), 124.3 (C(11)), 120.8 (C(6)), 61.9 (C(2’)), 61.7 (C(2’)), 58.5 (C(1)), 51.8 (C(14)), 44.8 (C(2)), 40.8 (C(12)), 39.4 (C(5)), 39.1 (C(4)), 26.8 $(\mathrm{C}(7)), 14.3\left(\mathrm{C}\left(3^{\prime}\right)\right), 14.2\left(\mathrm{C}\left(3^{\prime}\right)\right),-1.8(\mathrm{CSi})$.

$\underline{\text { IR: (neat) }}$

2982 (m), 2954 (m), 1732 (s), 1630 (w), 1494 (m), 1437 (m), 1366 (m), 1250 (s), 1179 (s), 1073 (m), 1059 (m), 834 (m), 700 (m). 
LRMS: (CI):

477 (44.4, $\left.[\mathrm{M}+\mathrm{H}]^{+}\right), 431$ (16.4), 355 (100.0), 267 (14.0), 207 (16.2), 63 (28.0).

HRMS: $\left(\mathrm{CI},[\mathrm{M}+\mathrm{H}]^{+}\right)$:

calcd.: 447.2171

found: 447.2200

Analysis: $\mathrm{C}_{24} \mathrm{H}_{34} \mathrm{O}_{6} \mathrm{Si} \quad(446.61)$

calcd.: C, 64.54; $\quad \mathrm{H}, 7.67$.

found: C, 64.42; $\quad \mathrm{H}, 7.87$.

Rf: $\quad 0.39$ (silica gel, hexane/EtOAc, 5/1, UV)

$\underline{t_{\mathrm{R}}}: \quad 2.75 \mathrm{~min}$ (Agilent Zorbax 300SB-C8, 100\% MeCN (1 mL/min))

Carbonylative Silylcarbocyclization Reaction of 4,4-Bis(carboethoxy)-6-hepten-1-yne (1) with Benzyldimethylsilane. Preparation of Diethyl (Z)-3-Benzyldimethylsilylmethylene-4oxoethylcyclopentane-1,1-dicarboxylate (11).

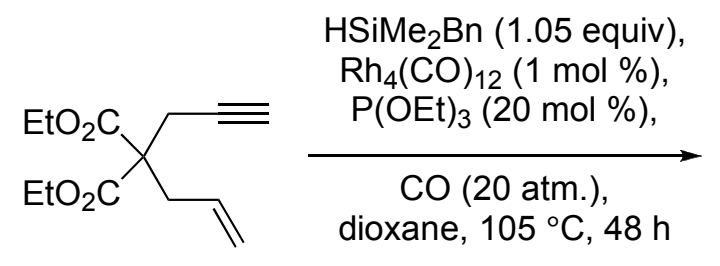

1

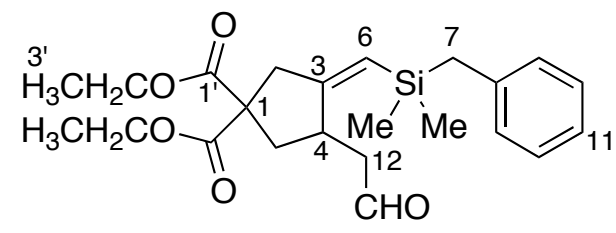

11

In an flame-dried glass liner $(\varnothing=7 \mathrm{~cm})$ with a magnetic stirrer and a gas inlet adaptor, 4,4-bis(carboethoxy)-6-hepten-1-yne (1) $\quad\left(\begin{array}{llllll}715 & \mathrm{mg}, & 3.00 & \mathrm{mmol}, & 1.0 & \text { equiv }) \text { and }\end{array}\right.$ benzyldimethylsilane $(0.5 \mathrm{~mL}, 3.15 \mathrm{mmol}, 1.05$ equiv) were dissolved in dioxane $(150 \mathrm{~mL})$, which was saturated with $\mathrm{CO}$ by bubbling for approximately $30 \mathrm{~min}$. In another flame-dried, 25$\mathrm{mL}$, round-bottomed flask equipped with a magnetic stirrer and a gas inlet adaptor, a red solution of $\mathrm{Rh}_{4}(\mathrm{CO})_{12}(22 \mathrm{mg}, 0.03 \mathrm{mmol}, 1 \mathrm{~mol} \%)$ in dioxane $(6 \mathrm{~mL})$ was prepared by stirring at room temperature under $\mathrm{CO}$ for $5 \mathrm{~min}$. Both vessels were purged with $\mathrm{CO}$. The solution containing $\mathrm{Rh}_{4}(\mathrm{CO})_{12}$ was added a solution of $\mathrm{P}(\mathrm{OEt})_{3}(0.1 \mathrm{~mL}, 0.60 \mathrm{mmol}, 20 \mathrm{~mol} \%)$ in dioxane $(6 \mathrm{~mL})$, and the color of the mixture immediately turned to dark-red. This dark-red solution was stirred at room temperature under a $\mathrm{CO}$ atmosphere for $10 \mathrm{~min}$, and it was subsequently added to the solution containing 4,4-bis(carboethoxy)-6-hepten-1-yne (1) in the liner via cannulation under $\mathrm{CO}$. When the addition was completed, the liner was removed from the CO manifold and was 
quickly transferred into the autoclave. The autoclave was sealed and was then purged with CO by pressurize to approximately $20 \mathrm{~atm}$ followed by venting. The purging process was repeated twice. Then the autoclave was pressurized with $\mathrm{CO}$ to $20 \mathrm{~atm}$ and was placed in an oil bath, in which the reaction mixture was heated to $105^{\circ} \mathrm{C}$ and was stirred for $48 \mathrm{~h}$. When the reaction period had completed, the autoclave was allowed to cool down to room temperature before the $\mathrm{CO}$ was vented. The reaction mixture, which had turned into a bright-yellow solution, was treated with a solution of thiourea $(22 \mathrm{mg}, 0.30 \mathrm{mmol}, 10 \mathrm{~mol} \%)$ in EtOH $(5 \mathrm{~mL})$. This mixture was stirred at room temperature under air for approximately $20 \mathrm{~min}$, and it was concentrated under reduced pressure. The resulting crude product was purified using flash chromatography (silica gel $(120 \mathrm{~g})$, hexane/EtOAc, 40/1 $(500 \mathrm{~mL}), 30 / 1(500 \mathrm{~mL}), 20 / 1(500 \mathrm{~mL}), 10 / 1(500$ $\mathrm{mL}), 5 / 1(500 \mathrm{~mL}))$ and diffusion pump distillation to afford $891 \mathrm{mg}(71 \%)$ of $\mathbf{1 1}$ as a colorless, viscous liquid.

\section{Data for 11:}

b.p.: $\quad 200^{\circ} \mathrm{C}(\mathrm{ABT})$ at $1.6 \times 10^{-4} \mathrm{mmHg}$

${ }^{1} \mathrm{H}$ NMR: $\quad\left(500 \mathrm{MHz}, \mathrm{CDCl}_{3}\right)$

$9.63(\mathrm{~d}, 1 \mathrm{H}, J=0.4, \mathrm{HC}(13)), 7.21$ (t, $2 \mathrm{H}, J=7.6,2 \times \mathrm{HC}(10)), 7.08$ (t, $1 \mathrm{H}, J=$ 7.6, $\mathrm{HC}(11)), 6.98$ (d, $2 \mathrm{H}, J=7.1,2 \times \mathrm{HC}(9)), 5.41$ (d, $1 \mathrm{H}, J=1.0, \mathrm{HC}(6)), 4.19$ (q, $2 \mathrm{H}, J=7.1, \mathrm{H}_{2} \mathrm{C}\left(2^{\prime}\right)$ ), 4.19 (q, $2 \mathrm{H}, J=7.1, \mathrm{H}_{2} \mathrm{C}\left(2^{\prime}\right)$ ), 3.17 (dt, $1 \mathrm{H}, J=16.6$, 2.1, HC(2)), 3.04-3.01 (m, $1 \mathrm{H}, \mathrm{HC}(4)), 2.86$ (d, $1 \mathrm{H}, J=16.4, \mathrm{HC}(2)), 2.67$ (dd, 1 $\mathrm{H}, J=14.1,8.2, \mathrm{HC}(5)$ ), 2.45 (ddd, $1 \mathrm{H}, J=17.8,11.2,1.7, \mathrm{HC}(12)$ ), 2.23 (dd, 1 $\mathrm{H}, J=17.8,2.9, \mathrm{HC}(12)), 2.12$ (s, $\left.2 \mathrm{H}, \mathrm{H}_{2} \mathrm{C}(7)\right), 1.96$ (dd, $1 \mathrm{H}, J=13.9,4.4$, $\mathrm{HC}(5)), 1.25$ (t, $3 \mathrm{H}, J=7.3, \mathrm{H}_{3} \mathrm{C}\left(3^{\prime}\right)$ )), 1.24 (t, $\left.3 \mathrm{H}, J=7.1, \mathrm{H}_{3} \mathrm{C}\left(3^{\prime}\right)\right), 0.09$ (s, 3 $\left.\mathrm{H}, \mathrm{H}_{3} \mathrm{CSi}\right), 0.08$ (s, $3 \mathrm{H}, \mathrm{H}_{3} \mathrm{CSi}$ ).

${ }^{13} \mathrm{C} \mathrm{NMR}: \quad\left(126 \mathrm{MHz}, \mathrm{CDCl}_{3}\right)$

$200.8(C(13)), 172.3\left(\mathrm{C}\left(1^{\prime}\right)\right), 171.6\left(\mathrm{C}\left(1^{\prime}\right)\right), 161.4(\mathrm{C}(3)), 140.0(\mathrm{C}(8)), 128.5$ (C(9) or $\mathrm{C}(10)), 128.4(\mathrm{C}(9)$ or $\mathrm{C}(10)), 124.4(\mathrm{C}(11)), 120.4(\mathrm{C}(6)), 61.9\left(\mathrm{C}\left(2^{\prime}\right)\right)$, $61.8\left(\mathrm{C}\left(2^{\prime}\right)\right), 58.6(\mathrm{C}(1)), 50.7(\mathrm{C}(5)), 44.8(\mathrm{C}(2)), 39.6(\mathrm{C}(12)), 36.5(\mathrm{C}(4)), 26.9$ $(\mathrm{C}(7)), 14.3\left(\mathrm{C}\left(3^{\prime}\right)\right), 14.2\left(\mathrm{C}\left(3^{\prime}\right)\right),-1.6(\mathrm{CSi}),-1.8(\mathrm{CSi})$.

IR: (neat)

$2981(\mathrm{~m}), 1730(\mathrm{~s}), 1631(\mathrm{w}), 1494(\mathrm{~m}), 1452(\mathrm{w}), 1367$ (w), $1249(\mathrm{~s}), 1186(\mathrm{~m})$, $1158(\mathrm{~m}), 1082(\mathrm{w}), 1060(\mathrm{w}), 837(\mathrm{~m}), 700(\mathrm{~m})$. 
LRMS: (CI):

417 (22.5, [M+H] $\left.]^{+}\right), 399$ (15.1), 343 (15.2), 325 (51.6), 297 (6.4), 279 (12.1), 251

(57.5), 223 (8.9), 205 (15.1), 177 (100.0), 149 (13.5).

HRMS: $\left(\mathrm{CI},[\mathrm{M}+\mathrm{H}]^{+}\right)$:

calcd.: 417.209399

found: 417.209265

Analysis: $\mathrm{C}_{22} \mathrm{H}_{32} \mathrm{O}_{5} \mathrm{Si} \quad(416.58)$

calcd.: C, 66.31; $\quad$ H, 7.74.

found: $\mathrm{C}, 66.22 ; \quad \mathrm{H}, 7.95$.

$\underline{\mathrm{R}}_{\mathrm{f}}: \quad 0.38$ (silica gel, hexane/EtOAc, 5/1, UV)

$\underline{t_{\underline{R}}}: \quad 2.83 \mathrm{~min}$ (Agilent Zorbax 300SB-C8, 100\% MeCN (1 mL/min))

General Procedure of the Survey of Palladium Catalysts for the Cross-Coupling of 6 with Ethyl 4-Iodobenzoate.

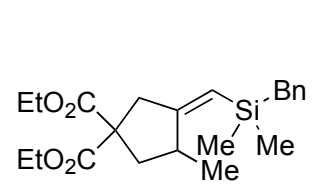

6

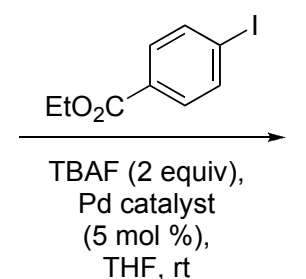

THF, rt

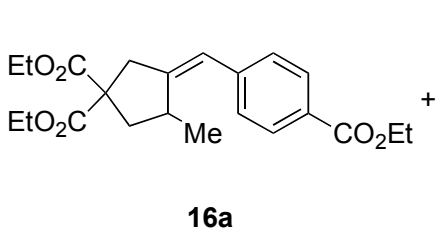

$16 a$

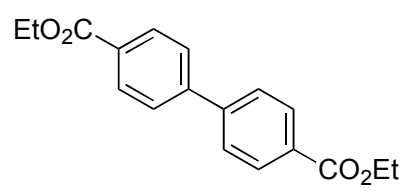

17

Alkylidenylsilane 6 ( $78 \mathrm{mg}, 0.20 \mathrm{mmol}, 1.0$ equiv) and naphthalene (26 mg, $0.20 \mathrm{mmol}$ ) were dissolved in a solution of TBAF• $3 \mathrm{H}_{2} \mathrm{O}(1.0 \mathrm{M}$ in THF, $0.40 \mathrm{~mL}, 0.40 \mathrm{mmol}, 2.0$ equiv $)$ in a 5-mL, round-bottomed flask with a magnetic stir bar fitted with a gas inlet adaptor, and the resulting light-yellow solution was stirred for approximately $3 \mathrm{~min}$. Then ethyl 4-iodobenzoate (34 $\mu \mathrm{L}, 0.20 \mathrm{mmol}, 1.0$ equiv) and the palladium complex (5 mol \% Pd used) were added to the solution sequentially. The flask was purged with Ar, and the reaction mixture was stirred at room temperature under $\mathrm{Ar}$ atmosphere. The reaction was monitored by GC analysis at certain intervals until the formation of desired product 16a stopped. Sampling of the reaction was performed by removing $20 \mu \mathrm{L}$ aliquot of the mixture via syringe. The aliquot was quenched by a solution $(40 \mu \mathrm{L})$ of dimethylaminoethanethiol $\cdot \mathrm{HCl}(10 \mathrm{wt} \%$ in water), and the mixture was loaded onto a small plug of silica gel and eluted with $8 \mathrm{~mL}$ of $\mathrm{MeCN}$. The aliquot was then 
analyzed by HPLC using the general HPLC shown below. Response factors $\left(\mathrm{R}_{\mathrm{f}}\right)$ were obtained by equation 1 and are shown below:

Eq 1: Response factor for $\mathrm{A}=\frac{(\mathrm{mmol} \mathrm{A} \times \text { area naphthalene })}{(\mathrm{mmol} \text { naphthalene } \times \text { area } \mathrm{A})}$

\begin{tabular}{|c|c|c|c|c|}
\hline $\begin{array}{c}\text { naphthalene } \\
\text { (mmol) }\end{array}$ & $\begin{array}{c}\text { naphthalene } \\
\text { (area) }\end{array}$ & $\begin{array}{c}\text { Ethyl 4- } \\
\text { iodobenzoate } \\
\text { (mmol) }\end{array}$ & $\begin{array}{c}\text { Ethyl 4- } \\
\text { iodobenzoate } \\
\text { (area) }\end{array}$ & $\begin{array}{l}\text { response factor } \\
\qquad\left(\mathrm{R}_{\mathrm{f}}\right)\end{array}$ \\
\hline 0.09519 & 6201.1740 & 0.09345 & 12326.3780 & 0.4939 \\
\hline 0.09519 & 5291.1790 & 0.09345 & 11694.1890 & 0.4442 \\
\hline 0.09519 & 7150.4010 & 0.09345 & 13121.7800 & 0.5134 \\
\hline $\begin{array}{l}\text { naphthalene } \\
\text { (mmol) }\end{array}$ & $\begin{array}{c}\text { naphthalene } \\
\text { (area) }\end{array}$ & $16 \mathbf{a}(\mathrm{mmol})$ & $16 \mathbf{a}($ area $)$ & $\begin{array}{c}\text { response factor } \\
\left(\mathrm{R}_{\mathrm{f}}\right)\end{array}$ \\
\hline 0.09987 & 858.3210 & 0.05196 & 1814.9010 & 0.2461 \\
\hline 0.09987 & 1733.6155 & 0.05196 & 3407.5163 & 0.2647 \\
\hline 0.09987 & 1078.3440 & 0.05196 & 2257.7180 & 0.2485 \\
\hline 0.1030 & 1406.8980 & 0.04894 & 2552.8720 & 0.2619 \\
\hline 0.1030 & 1011.8490 & 0.04894 & 1911.9770 & 0.2515 \\
\hline 0.1030 & 809.1140 & 0.04894 & 1529.8480 & 0.2512 \\
\hline $\begin{array}{l}\text { naphthalene } \\
\text { (mmol) }\end{array}$ & $\begin{array}{c}\text { naphthalene } \\
\text { (area) }\end{array}$ & 17 (mmol) & 17 (area) & $\begin{array}{c}\text { response factor } \\
\left(\mathrm{R}_{\mathrm{f}}\right)\end{array}$ \\
\hline 0.09753 & 7027.8688 & 0.03063 & 5293.7525 & 0.4169 \\
\hline 0.09753 & 6476.3840 & 0.03063 & 5067.9850 & 0.4013 \\
\hline 0.09753 & 7272.048 . & 0.03063 & 5832.5085 & 0.3916 \\
\hline 0.1061 & 5634.4310 & 0.03627 & 4930.0545 & 0.3906 \\
\hline 0.1061 & 7744.4018 & 0.03627 & 6920.7515 & 0.3825 \\
\hline 0.1061 & 7426.8445 & 0.03627 & 6701.0830 & 0.3789 \\
\hline
\end{tabular}


Eq 2: HPLC yield of $\mathrm{A}=\frac{(\text { area } \mathrm{A} / \mathrm{mmol} \mathrm{A})}{(\text { area naphthalene } / \mathrm{mmol} \text { naphthalene })} \times \mathrm{Rf} \mathrm{A}$

\section{General HPLC Method}

Injections were made onto an Agilent Zorbax 300-SB C8 column. Compounds were separated using a gradient of increasing concentration of acetonitrile in a mobile phase of $\mathrm{MeCN} /$ water, 60/40 (1 $\mathrm{mL} / \mathrm{min})$. The column solvent gradient program is as follows: $60 \%$ $(\mathrm{MeCN})$ to $100 \% \mathrm{ramp}$ at $4 \% / \mathrm{min}, 100 \%$ for $2 \mathrm{~min}, 100 \%$ to $60 \%$ gradient at $11.4 \% / \mathrm{min}$. The total run time is $16 \mathrm{~min}$.

\section{Table 2, entry 1}

Following the General Procedure, 6 (78 mg, $0.20 \mathrm{mmol}, 1.0$ equiv) and naphthalene (26 $\mathrm{mg}, 0.20 \mathrm{mmol}, 1.0$ equiv) in a $10-\mathrm{mL}$, round-bottomed flask equipped with a gas inlet adaptor and a magnetic stirrer was dissolved in a solution of TBAF• $3 \mathrm{H}_{2} \mathrm{O}(1.0 \mathrm{M}$ in THF, $0.4 \mathrm{~mL}, 0.40$ mmol, 2.0 equiv), and stirred for approximately $3 \mathrm{~min}$. Then ethyl 4-iodobenzoate (34 $\mu \mathrm{L}, 0.20$ $\mathrm{mmol})$ and $\mathrm{Pd}(\mathrm{dba})_{2}(6 \mathrm{mg}, 0.05 \mathrm{mmol}, 5 \mathrm{~mol} \%)$ were added to the solution sequentially. The flask was purged with Ar, and the reaction mixture was stirred at room temperature under Ar atmosphere for $4 \mathrm{~h}$. An aliquot of the mixture was then taken for HPLC analysis using the general HPLC method. 2 h: 17, $t_{\mathrm{R}} 6.86 \min (33.9,1 \%) ; \mathbf{1 6 a}, t_{\mathrm{R}} 7.70 \mathrm{~min}(2009.6,92 \%) 4 \mathrm{~h}: \mathbf{1 7}$, $t_{\mathrm{R}} 6.88 \min (29.7,2 \%) ; \mathbf{1 6 a}, t_{\mathrm{R}} 7.72 \min (1134.6,104 \%)$.

\section{Table 2, entry 2}

Following the General Procedure, 6 (78 $\mathrm{mg}, 0.20 \mathrm{mmol}, 1.0$ equiv) and naphthalene (26 $\mathrm{mg}, 0.20 \mathrm{mmol}, 1.0$ equiv) in a $10-\mathrm{mL}$, round-bottomed flask equipped with a gas inlet adaptor and a magnetic stirrer were dissolved in a solution of TBAF• $3 \mathrm{H}_{2} \mathrm{O}(1.0 \mathrm{M}$ in THF, $0.4 \mathrm{~mL}, 0.40$ mmol, 2.0 equiv), and stirred for approximately $3 \mathrm{~min}$. Then ethyl 4-iodobenzoate $(34 \mu \mathrm{L}, 0.20$ mmol, 1.0 equiv) and $\mathrm{Pd}_{2}(\mathrm{dba})_{3}(5 \mathrm{mg}, 0.025 \mathrm{mmol}, 2.5 \mathrm{~mol} \%)$ were added to the solution sequentially. The flask was purged with Ar, and the reaction mixture was stirred at room temperature under Ar atmosphere for $4 \mathrm{~h}$. An aliquot of the mixture was then taken for HPLC analysis using the general HPLC method. $2 \mathrm{~h}: 17, t_{\mathrm{R}} 6.73 \mathrm{~min}(45.0,1 \%) ; 16 \mathrm{a}, t_{\mathrm{R}} 7.55 \mathrm{~min}$ (1785.4, 83\%). 4 h: 17, $t_{\mathrm{R}} 6.73 \min (50.8,2 \%)$; 16a, $t_{\mathrm{R}} 7.54 \min (1306.9,90 \%)$. 


\section{Table 2, entry 3}

Following the General Procedure, 6 (78 $\mathrm{mg}, 0.20 \mathrm{mmol}, 1.0$ equiv) and naphthalene (26 $\mathrm{mg}, 0.20 \mathrm{mmol}, 1.0$ equiv) in a $10-\mathrm{mL}$, round-bottomed flask equipped with a gas inlet adaptor and a magnetic stirrer was dissolved in a solution of TBAF• $3 \mathrm{H}_{2} \mathrm{O}(1.0 \mathrm{M}$ in THF, $0.4 \mathrm{~mL}, 0.40$ mmol, 2.0 equiv), and stirred for approximately $3 \mathrm{~min}$. Then ethyl 4-iodobenzoate (34 $\mu \mathrm{L}, 0.20$ mmol, 1.0 equiv) and $\mathrm{Pd}_{2}(\mathrm{dba})_{3} \cdot \mathrm{CHCl}_{3}(5 \mathrm{mg}, 0.025 \mathrm{mmol}, 2.5 \mathrm{~mol} \%)$ were added to the solution sequentially. The flask was purged with Ar, and the reaction mixture was stirred at room temperature under Ar atmosphere for $4 \mathrm{~h}$. An aliquot of the mixture was then taken for HPLC analysis using the general HPLC method. $2 \mathrm{~h}: 17, t_{\mathrm{R}} 6.89 \mathrm{~min}(18.2,1 \%) ; 16 a, t_{\mathrm{R}} 7.73 \mathrm{~min}$ (881.8, 99\%). 4 h: 17, $t_{\mathrm{R}} 6.88 \min (47.9,2 \%) ; 16 a, t_{\mathrm{R}} 7.72 \min (1489.5,100 \%)$.

\section{Table 2, entry 4}

Following the General Procedure, 6 (78 mg, $0.20 \mathrm{mmol}, 1.0$ equiv) and naphthalene (26 $\mathrm{mg}, 0.20 \mathrm{mmol}, 1.0$ equiv) in a $10-\mathrm{mL}$, round-bottomed flask equipped with a gas inlet adaptor and a magnetic stirrer was dissolved in a solution of TBAF $3 \mathrm{H}_{2} \mathrm{O}(1.0 \mathrm{M}$ in THF, $0.4 \mathrm{~mL}, 0.40$ mmol, 2.0 equiv), and stirred for approximately $3 \mathrm{~min}$. Then ethyl 4-iodobenzoate (34 $\mu \mathrm{L}, 0.20$ mmol, 1.0 equiv) and $[\pi \text {-allylPdCl}]_{2}(2 \mathrm{mg}, 0.025 \mathrm{mmol}, 2.5 \mathrm{~mol} \%)$ were added to the solution sequentially. The flask was purged with Ar, and the reaction mixture was stirred at room temperature under Ar atmosphere for $4 \mathrm{~h}$. An aliquot of the mixture was then taken for HPLC analysis using the general HPLC method. $2 \mathrm{~h}: 17, t_{\mathrm{R}} 6.88 \min (17.8,1 \%) ; 16 \mathbf{1}, t_{\mathrm{R}} 7.71 \mathrm{~min}$ $(1033.4,80 \%) 4$ h: 17, $t_{\mathrm{R}} 6.89 \min (24.3,3 \%) ; \mathbf{1 6 a}, t_{\mathrm{R}} 7.70 \min (460.4,78 \%)$.

Cross-Coupling Reaction of 6 with Ethyl 4-Iodobenzoate. Preparation of Diethyl (Z)-3-(4Ethoxycarbonylbenzylidene)-4-methylcyclopentane-1,1-dicarboxylate (16a).

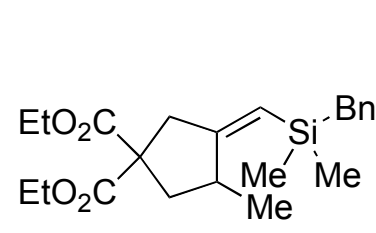

6

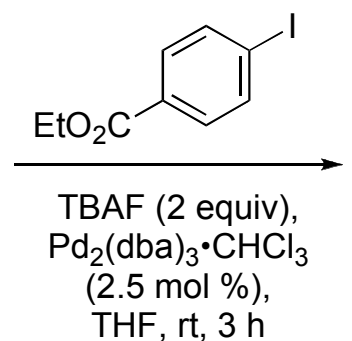

$\mathrm{THF}, \mathrm{rt}, 3 \mathrm{~h}$

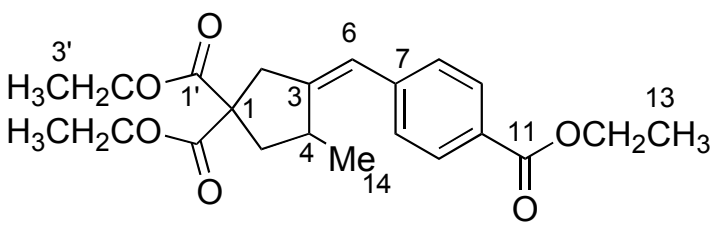

$16 a$

Alkylidenylsilane 6 (428 mg, $1.10 \mathrm{mmol}, 1.1$ equiv) in a 5-mL, round-bottomed flask with a magnetic stir bar and fitted with a gas inlet adaptor was dissolved in a solution of 
$\mathrm{TBAF} \cdot 3 \mathrm{H}_{2} \mathrm{O}(1.0 \mathrm{M}$ in THF, $2.0 \mathrm{~mL}, 2.0 \mathrm{mmol}, 2.0$ equiv), and the resulting light-yellow solution was stirred at room temperature under Ar for $3 \mathrm{~min}$. Then ethyl 4-iodobenzoate $(167 \mu \mathrm{L}$, $1.00 \mathrm{mmol}, 1.0$ equiv) and $\mathrm{Pd}_{2}(\mathrm{dba})_{3} \cdot \mathrm{CHCl}_{3}(26 \mathrm{mg}, 0.025 \mathrm{mmol}, 2.5 \mathrm{~mol} \%)$ were added to the solution sequentially. The flask was purged with Ar, and the reaction mixture was stirred at room temperature under Ar atmosphere for $3 \mathrm{~h}$. Then, the reaction mixture was passed through thin layer of silica gel (approximately $1 \mathrm{~cm})$ followed by a wash of EtOAc $(100 \mathrm{~mL})$. The darkbrown filtrate was added silica gel $(1 \mathrm{~g})$ and was concentrated under reduced pressure. The crude product adsorbed on silica gel was purified using flash chromatography (first column: silica gel (45 g), hexane/EtOAc, 40/1 (500 mL), 20/1 (1.25 L), second column: silica gel (45 g), hexane/EtOAc $=50 / 1(250 \mathrm{~mL}), 40 / 1(750 \mathrm{~mL}), 20 / 1(500 \mathrm{~mL}), 10 / 1(500 \mathrm{~mL}))$, reverse phase flash chromatography (reverse phase silica gel $(20 \mathrm{~g}), \mathrm{MeCN} / \mathrm{H}_{2} \mathrm{O}, 1 / 1(250 \mathrm{~mL}), 2 / 1(250 \mathrm{~mL})$, $3 / 1(250 \mathrm{~mL}))$, and diffusion pump distillation to afford $350 \mathrm{mg}(90 \%)$ of $\mathbf{1 6 a}$ as a colorless, viscous liquid.

\section{Data for 16a:}

b.p.: $\quad 175^{\circ} \mathrm{C}(\mathrm{ABT})$ at $9.0 \times 10^{-5} \mathrm{mmHg}$

${ }^{1} \mathrm{H}$ NMR: $\quad\left(500 \mathrm{MHz}, \mathrm{CDCl}_{3}\right)$

$7.98(\mathrm{dd}, 2 \mathrm{H}, J=6.6,1.7,2 \times \mathrm{HC}(9)), 7.33(\mathrm{~d}, 2 \mathrm{H}, J=8.4,2 \times \mathrm{HC}(8)), 6.37(\mathrm{~s}, 1$ $\mathrm{H}, \mathrm{HC}(6)), 4.37$ (q, $\left.2 \mathrm{H}, J=7.1, \mathrm{H}_{2} \mathrm{C}(12)\right)$, 4.26-4.17 (m, $\left.4 \mathrm{H}, 2 \times \mathrm{H}_{2} \mathrm{C}\left(2^{\prime}\right)\right), 3.30$ (dt, $1 \mathrm{H}, J=16.3,2.1, \mathrm{HC}(2)), 3.36-3.33$ (m, $1 \mathrm{H}, \mathrm{HC}(4)), 3.00$ (d, $1 \mathrm{H}, J=16.3$, $\mathrm{HC}(2)), 2.76$ (ddd, $1 \mathrm{H}, J=13.3,8.0,1.4, \mathrm{HC}(5)), 1.97$ (dd, $1 \mathrm{H}, J=13.3,6.2$, $\mathrm{HC}(5)), 1.40$ (t, $\left.3 \mathrm{H}, J=7.1, \mathrm{H}_{3} \mathrm{C}(13)\right), 1.39$ (t, $\left.3 \mathrm{H}, J=6.6, \mathrm{H}_{3} \mathrm{C}\left(3^{\prime}\right)\right)$ ), 1.25 (t, 3 $\left.\mathrm{H}, J=6.5, \mathrm{H}_{3} \mathrm{C}\left(3^{\prime}\right)\right), 1.06\left(\mathrm{~d}, 3 \mathrm{H}, J=7.9, \mathrm{H}_{3} \mathrm{C}(14)\right)$.

${ }^{13} \mathrm{C}$ NMR: $\quad\left(126 \mathrm{MHz}, \mathrm{CDCl}_{3}\right)$

172.0 (C(1')), 171.9 (C(1')), 166.7 (C(11)), 149.9 (C(3)), 142.3 (C(7)), 129.8 (C(9)), 129.8 (C(10), C(8)), 122.0 (C(6)), 61.8 (C(2’)), 61.8 (C(2’)), 61.1 (C(12)), 58.4 (C(1)), 43.4 (C(2)), 42.6 (C(5)), 34.9 (C(4)), 19.6 (C(14)), 14.5 (C(13)), 14.2 $\left(\mathrm{C}\left(3^{\prime}\right)\right)$.

IR: (neat)

3463 (w), 2980 (s), 1732 (s), 1606 (s), 1447 (m), 1367 (m), 1274 (s), 1178 (s), 1108 (s), 1068 (s), 1021 (s), 877 (m), 772 (m). 
LRMS: (EI):

241 (53.0), 268 (13.5), 269 (13.7), 314 (100.0), 343 (13.4), 388 (21.0, [M] $\left.{ }^{+}\right)$.

HRMS: (EI, $\left.[\mathrm{M}]^{+}\right)$:

calcd.: 388.188589

found: 388.188594

Analysis: $\mathrm{C}_{22} \mathrm{H}_{28} \mathrm{O}_{6} \quad(388.45)$

calcd.: C, 68.02; $\quad \mathrm{H}, 7.27$.

found: C, 68.27; $\quad \mathrm{H}, 7.37$.

․ㅡㄹ $\quad 0.35$ (silica gel, hexane/EtOAc, 5/1, UV)

$\underline{t_{\mathrm{R}}}$ : $\quad 3.075 \mathrm{~min}$ (Agilent Zorbax 300SB-C8, 100\% MeCN (1 mL/min))

Cross-Coupling Reaction of 6 with 4-Iodoacetophenone. Preparation of Diethyl (Z)-3-(4Methylcarbonylbenzylidene)-4-methylcyclopentane-1,1-dicarboxylate (16b).

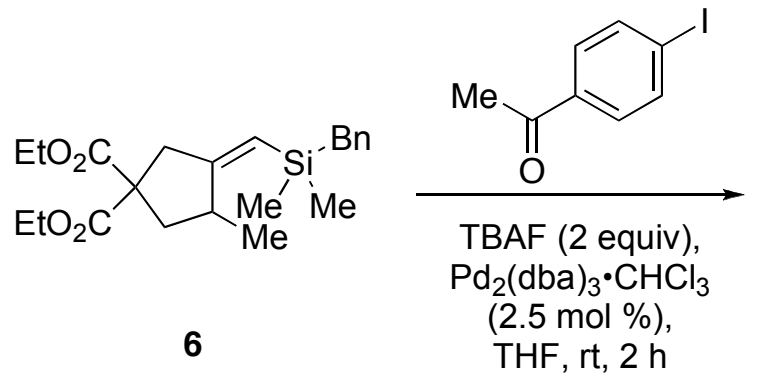

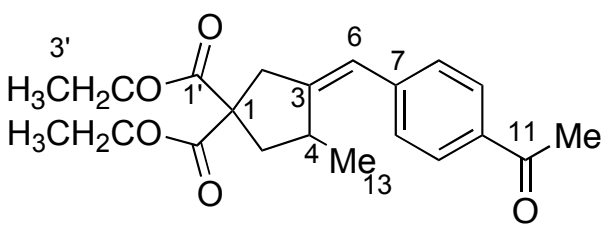

$16 b$

Alkylidenylsilane 6 (426 mg, $1.10 \mathrm{mmol}, 1.1$ equiv) in a 5-mL, round-bottomed flask with a magnetic stir bar and fitted with a gas inlet adaptor, was dissolved in a solution of TBAF $• 3 \mathrm{H}_{2} \mathrm{O}(1.0 \mathrm{M}$ in THF, $2.0 \mathrm{~mL}, 2.0 \mathrm{mmol}, 2.0$ equiv) and the resulting light-yellow solution was stirred at room temperature under $\mathrm{Ar}$ for approximately $3 \mathrm{~min}$. Then 4iodoacetophenone (247 mg, $1.00 \mathrm{mmol}, 1.0$ equiv) and $\mathrm{Pd}_{2}\left(\mathrm{dba}_{3}{ }^{\circ} \mathrm{CHCl}_{3}(26 \mathrm{mg}, 0.025 \mathrm{mmol}\right.$, $2.5 \mathrm{~mol} \%$ ) were added to the solution sequentially. The flask was purged with Ar, and the reaction mixture was stirred at room temperature under $\mathrm{Ar}$ atmosphere for $2 \mathrm{~h}$. Then, the reaction mixture was passed through thin layer of silica gel (approximately $1 \mathrm{~cm}$ ) followed by a wash of EtOAc $(100 \mathrm{~mL})$. The dark-brown filtrate was added silica gel $(1 \mathrm{~g})$ and was concentrated under reduced pressure. The crude product adsorbed on silica gel was purified using flash chromatography (silica gel (40 g), hexane/EtOAc, 40/1 (250 mL), 20/1 (250 mL), 10/1 (500 $\mathrm{mL}), 5 / 1(500 \mathrm{~mL}))$ and diffusion pump distillation to afford $308 \mathrm{mg}(86 \%)$ of $\mathbf{1 6} \mathbf{b}$ as a colorless, 
viscous liquid.

Data for 16b:

b.p.: $\quad 162{ }^{\circ} \mathrm{C}(\mathrm{ABT})$ at $1.2 \times 10^{-4} \mathrm{mmHg}$

${ }^{1} \mathrm{H}$ NMR: $\quad\left(500 \mathrm{MHz}, \mathrm{CDCl}_{3}\right)$

7.90 (d, $2 \mathrm{H}, J=7.9, \mathrm{HC}(9)), 7.36$ (d, $2 \mathrm{H}, J=8.4, \mathrm{HC}(8)$ ), 6.37 (s, $1 \mathrm{H}, \mathrm{HC}(6)$ ), 4.25-4.17 (m, $4 \mathrm{H}, 2 \times \mathrm{H}_{2} \mathrm{C}\left(2^{\prime}\right)$ ), 3.30 (dt, $1 \mathrm{H}, J=16.3,2.4, \mathrm{HC}(2)$ ), 3.30-3.28 (m, $1 \mathrm{H}, \mathrm{HC}(4)), 3.00$ (d, $1 \mathrm{H}, J=16.3, \mathrm{HC}(2)), 2.77$ (dd, $1 \mathrm{H}, J=13.2,8.0$, $\mathrm{HC}(5)), 2.60$ (s, 3H, $\left.\mathrm{H}_{3} \mathrm{C}(12)\right), 1.98$ (dd, $\left.1 \mathrm{H}, J=13.3,5.8, \mathrm{HC}(5)\right), 1.28$ (td, $3 \mathrm{H}$, $\left.J=7.2,0.8, \mathrm{H}_{3} \mathrm{C}\left(3^{\prime}\right)\right), 1.25$ (ts, $\left.3 \mathrm{H}, J=7.1,0.6, \mathrm{H}_{3} \mathrm{C}\left(3^{\prime}\right)\right), 1.07$ (d, $3 \mathrm{H}, J=6.9$, $\left.\mathrm{H}_{3} \mathrm{C}(12)\right)$.

${ }^{13} \mathrm{C} \mathrm{NMR}: \quad\left(126 \mathrm{MHz}, \mathrm{CDCl}_{3}\right)$

197.9 (C(11)), 172.0 (C(1')), 171.8 (C(1')), 150.3 (C(3)), 142.6 (C(10)), 135.0 (C(7)), $128.6(\mathrm{C}(9)), 128.5(\mathrm{C}(8)), 121.9(\mathrm{C}(6)), 61.8$ (C(2’)), 61.8 (C(2’)), 58.4 (C(12)), 43.4 (C(1)), 43.4 (C(2)), 42.6 (C(5)), 35.0 (C(4)), 26.7 (C(12)), 19.6 (C(14)), $19.6(\mathrm{C}(13)), 14.2\left(\mathrm{C}\left(3^{\prime}\right)\right)$.

IR: (neat)

3462 (w), 2980 (s), 2256 (w), 1732 (s), 1682 (s), 1602 (s), 1447 (m), 1412 (m), 1365 (s), 1268 (s), 1182 (s), 1099 (s), 1067 (s), 1033 (m), 916 (m), 870 (m), 733 (s).

LRMS: (EI):

211 (56.8), 284 (100.0), 313 (5.2), $358\left(25.1,[\mathrm{M}]^{+}\right)$

HRMS: (EI, $\left.[\mathrm{M}]^{+}\right)$:

calcd.: 358.178024

found: 358.178071

Analysis: $\mathrm{C}_{21} \mathrm{H}_{26} \mathrm{O}_{5} \quad$ (358.43)

calcd.: C, 70.37; H, 7.31.

found: $\mathrm{C}, 70.40 ; \quad \mathrm{H}, 7.32$.

距: $\quad 0.34$ (silica gel, hexane/EtOAc, 5/1, UV)

$\underline{t_{\mathrm{R}}}: \quad 3.050 \mathrm{~min}$ (Agilent Zorbax 300SB-C8, 100\% MeCN (1 mL/min)) 


\section{Cross-Coupling Reaction of 6 with 2-Iodotoluene. Preparation of Diethyl (Z)-3-(4-} Cyanobenzylidene)-4-methylcyclopentane-1,1-dicarboxylate (16c).

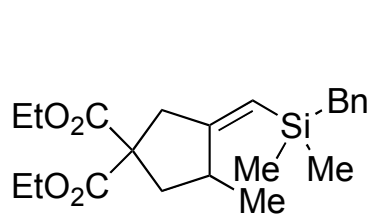

6

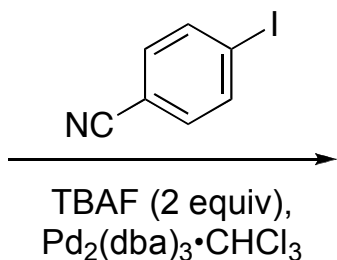

$(2.5 \mathrm{~mol} \%)$,

THF, rt, $24 \mathrm{~h}$

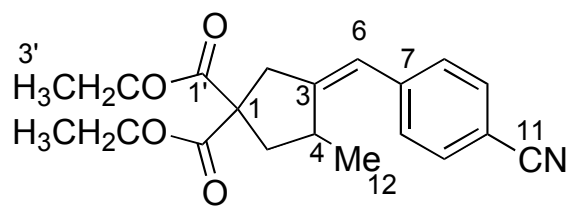

$16 c$

Alkylidenylsilane 6 (427 mg, $1.10 \mathrm{mmol}, 1.1$ equiv) in a 10-mL, round-bottomed flask with a magnetic stir bar and fitted with a gas inlet adaptor, was dissolved in a solution of $\mathrm{TBAF} \cdot 3 \mathrm{H}_{2} \mathrm{O}(1.0 \mathrm{M}$ in THF, $2.0 \mathrm{~mL}, 2.0 \mathrm{mmol}, 2.0$ equiv) and the resulting light-yellow solution was stirred at room temperature under Ar for approximately $3 \mathrm{~min}$. Then 4iodobenzonitrile (229 mg, $1.00 \mathrm{mmol}, 1.0$ equiv) and $\mathrm{Pd}_{2}(\mathrm{dba})_{3} \cdot \mathrm{CHCl}_{3}(26 \mathrm{mg}, 0.025 \mathrm{mmol}, 2.5$ mol \%) were added to the solution sequentially. The flask was purged with Ar, and the reaction mixture was stirred at room temperature under Ar atmosphere for $24 \mathrm{~h}$. Then, the reaction mixture was passed through thin layer of silica gel (approximately $1 \mathrm{~cm}$ ) followed by a wash of EtOAc $(100 \mathrm{~mL})$. The dark-brown filtrate was added silica gel $(1 \mathrm{~g})$ and was concentrated under reduced pressure. The crude product adsorbed on silica gel was purified using flash chromatography (silica gel (45 g), hexane/EtOAc, 40/1 (500 mL), 30/1 (500 L), 20/1 (1.5 L)), reverse phase flash chromatography (reverse phase silica gel (30 g), $\mathrm{MeCN} / \mathrm{H}_{2} \mathrm{O}, 5 / 1$ ), and diffusion pump distillation to afford $259 \mathrm{mg}(76 \%)$ of $\mathbf{1 6 c}$ as a colorless, viscous liquid.

Data for 16c:

b.p.: $167^{\circ} \mathrm{C}(\mathrm{ABT})$ at $9.0 \times 10^{-5} \mathrm{mmHg}$

${ }^{1} \mathrm{H}$ NMR: $\quad\left(500 \mathrm{MHz}, \mathrm{CDCl}_{3}\right)$

7.57 (d, 2 H, $J=8.3, \mathrm{HC}(9)), 7.34$ (d, 2 H, $J=8.3, \mathrm{HC}(8)), 5.33$ (s, $1 \mathrm{H}, \mathrm{HC}(6)$ ), 4.24-4.15 (m, 4 H, $\left.2 \times \mathrm{H}_{2} \mathrm{C}\left(2^{\prime}\right)\right), 3.29$ (dt, $\left.1 \mathrm{H}, J=16.4,2.4, \mathrm{HC}(2)\right), 3.24$ (dd, 1 $\mathrm{H}, J=8.0,1.7, \mathrm{HC}(4)), 2.98$ (d, $2 \mathrm{H}, J=16.4$, HC(2)), 2.74 (ddd, $1 \mathrm{H}, J=13.4$, 8.2, 1.4, $\mathrm{HC}(5)), 1.97\left(\mathrm{dd}, 1 \mathrm{H}, J=13.4,5.9, \mathrm{H}_{3} \mathrm{C}(5)\right), 1.26(\mathrm{t}, 3 \mathrm{H}, J=7.1$, $\left.\mathrm{H}_{3} \mathrm{C}\left(3^{\prime}\right)\right), 1.23$ (t, $\left.3 \mathrm{H}, J=7.1, \mathrm{H}_{3} \mathrm{C}\left(3^{\prime}\right)\right), 1.04$ (d, $\left.3 \mathrm{H}, J=6.8, \mathrm{H}_{3} \mathrm{C}(12)\right)$.

${ }^{13} \mathrm{C} \mathrm{NMR:} \quad\left(126 \mathrm{MHz}, \mathrm{CDCl}_{3}\right)$

171.8 (C(1')), 171.7 (C(1')), 151.4 (C(3)), 142.3 (C(7)), 132.2 (C(9)), 128.9 (C(8)), 121.3 (C(6)), 119.3 (C(11)), 109.7 (C(10)), 61.8 (C(2')), 61.8 (C(2’)), 58.2 
(C(1)), 43.3 (C(2)), $42.4(\mathrm{C}(5)), 34.9(\mathrm{C}(4)), 14.5$ (C(12)), 14.2 (C(3’)).

IR: (neat)

3458 (w), 2981 (m), 2226 (m), 1731 (s), 1604 (m), 1367 (m), 1276 (s), 1247 (s),

1178 (s), 1099 (m), 1068 (m), 1033 (m), 870 (m), 757 (w).

LRMS: (EI):

$341\left(16.0,[\mathrm{M}]^{+}\right), 267$ (91.3), 194 (87.5), 154 (26.2), 130 (100.0), 116 (21.0), 102

(60.2), 76 (28.3), 62 (39.3).

HRMS: (EI, $\left.[\mathrm{M}]^{+}\right)$:

calcd.: 341.162708

found: 341.162604

Analysis: $\mathrm{C}_{20} \mathrm{H}_{26} \mathrm{NO}_{4} \quad(341.40)$

calcd.: C, 70.36; H, 6.79; $\quad \mathrm{N}, 4.10$.

found: C, 70.05; $\mathrm{H}, 6.76 ; \quad \mathrm{N}, 4.25$.

$\underline{\mathrm{R}}_{\mathrm{f}}: \quad 0.31$ (silica gel, hexane/EtOAc, 5/1, UV)

$\underline{t_{\mathrm{R}}}: \quad 3.20 \mathrm{~min}$ (Agilent Zorbax 300SB-C8, 100\% MeCN (1 mL/min))

Cross-Coupling Reaction of 6 with 4-Iodoanisole. Preparation of Diethyl (Z)-3-(4Methoxybenzylidene)-4-methylcyclopentane-1,1-dicarboxylate (16d).

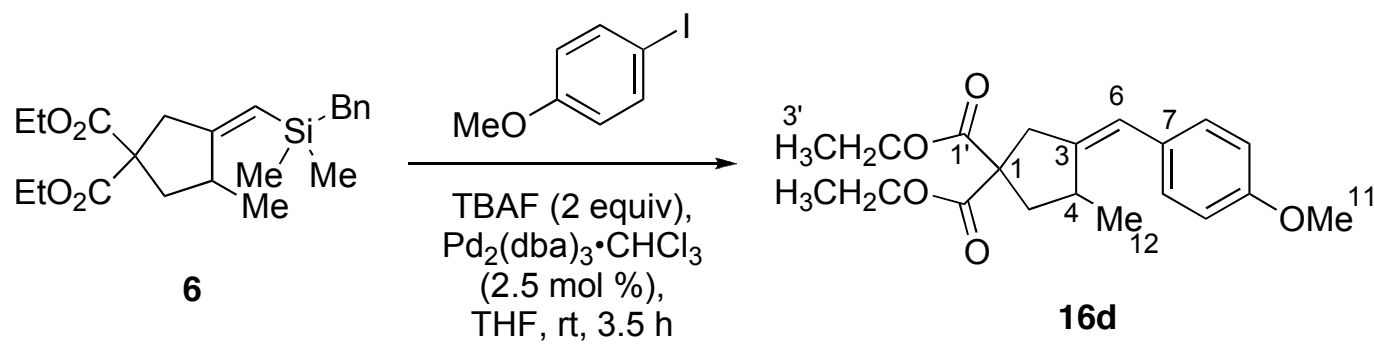

Alkylidenylsilane 6 (427 mg, $1.10 \mathrm{mmol}, 1.1$ equiv) in a 5-mL, round-bottomed flask with a magnetic stir bar and fitted with a gas inlet adaptor, was dissolved in a solution of $\mathrm{TBAF} \cdot 3 \mathrm{H}_{2} \mathrm{O}(1.0 \mathrm{M}$ in THF, $2.0 \mathrm{~mL}, 2.0 \mathrm{mmol}, 2.0$ equiv) and the resulting light-yellow solution was stirred at room temperature under Ar for approximately $3 \mathrm{~min}$. Then 4 -iodoanisole (234 mg, $1.00 \mathrm{mmol}, 1.0$ equiv) and $\mathrm{Pd}_{2}(\mathrm{dba})_{3} \cdot \mathrm{CHCl}_{3}(26 \mathrm{mg}, 0.025 \mathrm{mmol}, 2.5 \mathrm{~mol} \%$ ) were added to the solution sequentially. The flask was purged with Ar, and the reaction mixture was stirred at room temperature under Ar atmosphere for $3.5 \mathrm{~h}$. Then, the reaction mixture was passed through thin layer of silica gel (Approximately $1 \mathrm{~cm})$ followed by a wash of EtOAc $(100$ 
$\mathrm{mL})$. The dark-brown filtrate was added silica gel $(1 \mathrm{~g})$ and was concentrated under reduced pressure. The crude product adsorbed on silica gel was purified using flash chromatography (silica gel (40 g), hexane/EtOAc, 40/1 (1 L), 20/1 (750 mL)), reverse phase flash chromatography (reverse phase silica gel $(30 \mathrm{~g}), \mathrm{MeOH} / \mathrm{H}_{2} \mathrm{O}, 1 / 1(250 \mathrm{~mL}), 2 / 1(300 \mathrm{~mL}), 3 / 1$ $(450 \mathrm{~mL})$ ), and diffusion pump distillation to afford $286 \mathrm{mg}(82 \%)$ of $\mathbf{1 6 d}$ as a yellow, viscous liquid.

\section{Data for 16d:}

b.p.: $\quad 147^{\circ} \mathrm{C}(\mathrm{ABT})$ at $8.5 \times 10^{-5} \mathrm{mmHg}$

${ }^{1} \mathrm{H}$ NMR: $\quad\left(500 \mathrm{MHz}, \mathrm{CDCl}_{3}\right)$

$7.19(\mathrm{~d}, 2 \mathrm{H}, J=8.5,2 \times \mathrm{HC}(8)), 6.83$ (d, $2 \mathrm{H}, J=8.7,2 \times \mathrm{HC}(9)), 6.26$ (s, $1 \mathrm{H}$, $\mathrm{HC}(6))$, 4.24-4.15 (m, $4 \mathrm{H}, 2 \times \mathrm{H}_{2} \mathrm{C}\left(2^{\prime}\right)$ ), 3.80 (s, $3 \mathrm{H}, \mathrm{H}_{3} \mathrm{C}(11)$ ), 3.26 (dt, $1 \mathrm{H}, J=$ 16.9, 2.5, HC(2)), 3.24-3.20 (m, $1 \mathrm{H}, \mathrm{HC}(4)), 2.93$ (d, $1 \mathrm{H}, J=17.0, \mathrm{HC}(2)), 2.74$ (ddd, $1 \mathrm{H}, J=15.9,8.2,1.1, \mathrm{HC}(5)), 1.93$ (dd, $1 \mathrm{H}, J=13.2,6.4, \mathrm{HC}(5)), 1.26$ (t, $\left.3 \mathrm{H}, J=7.4, \mathrm{H}_{3} \mathrm{C}\left(3^{\prime}\right)\right), 1.23$ (t, $3 \mathrm{H}, J=7.2, \mathrm{H}_{3} \mathrm{C}\left(3^{\prime}\right)$ )), 1.07 (d, $3 \mathrm{H}, J=7.2$, $\left.\mathrm{H}_{3} \mathrm{C}(12)\right)$.

${ }^{13} \mathrm{C}$ NMR: $\quad\left(126 \mathrm{MHz}, \mathrm{CDCl}_{3}\right)$

$172.3\left(\mathrm{C}\left(1^{\prime}\right)\right), 172.0\left(\mathrm{C}\left(1^{\prime}\right)\right), 158.1(\mathrm{C}(3)), 145.0(\mathrm{C}(7)), 130.4(\mathrm{C}(10)), 129.6$ (C(9)), $122.0(\mathrm{C}(6)), 113.8(\mathrm{C}(8)), 61.7\left(\mathrm{C}\left(2^{\prime}\right)\right), 61.6\left(\mathrm{C}\left(2^{\prime}\right)\right), 58.5(\mathrm{C}(1)), 55.4$ (C(11)), $43.1(\mathrm{C}(2)), 42.7(\mathrm{C}(5)), 34.5(\mathrm{C}(4)), 19.6(\mathrm{C}(12)), 14.2\left(\mathrm{C}\left(3^{\prime}\right)\right)$.

IR: (neat)

3462 (s), 2979 (s), 1373 (s), 1732 (s), 1608 (s), 1511 (s), 1493 (m), 1463 (m), 1367 (m), 1246 (s), 1178 (s), 1098 (m), 1066 (m), 1034 (s), 863 (m), 824 (m).

LRMS: (EI):

121 (67.3), 199 (81.6), 272 (100.0), $346\left(44.0,[\mathrm{M}]^{+}\right)$.

HRMS: (EI, $\left.[\mathrm{M}]^{+}\right)$:

calcd.: 346.178024

found: 346.177374

Analysis: $\mathrm{C}_{20} \mathrm{H}_{26} \mathrm{O}_{5} \quad$ (346.42)

calcd.: C, 69.34; $\quad \mathrm{H}, 7.56$.

found: $\mathrm{C}, 69.30 ; \quad \mathrm{H}, 7.50$.

$\underline{\mathrm{R}}_{\mathrm{f}}: \quad 0.37$ (silica gel, hexane/EtOAc, 5/1, UV) 


\section{$\underline{t_{\mathrm{R}}}: \quad 6.875 \min ($ general HPLC method)}

Cross-Coupling Reaction of 6 with 2-Iodotoluene. Preparation of Diethyl (Z)-3-(2Methylbenzylidene)-4-methylcyclopentane-1,1-dicarboxylate (16e).
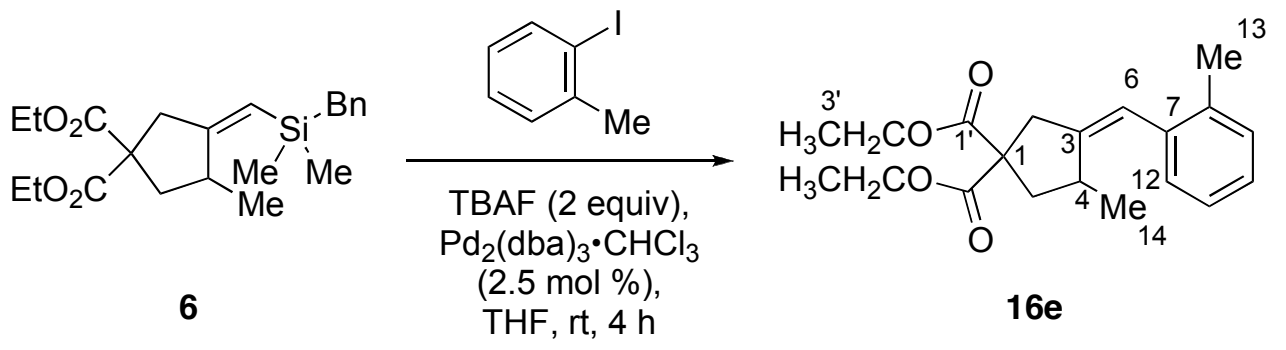

Benzylidenylsilane 6 (427 mg, $1.10 \mathrm{mmol}, 1.1$ equiv) in a 5-mL, round-bottomed flask with a magnetic stir bar and fitted with a gas inlet adaptor, was dissolved in a solution of $\mathrm{TBAF} \cdot 3 \mathrm{H}_{2} \mathrm{O}(1.0 \mathrm{M}$ in THF, $2.0 \mathrm{~mL}, 2.0 \mathrm{mmol}, 2.0$ equiv) and the resulting light-yellow solution was stirred at room temperature under Ar for approximately $3 \mathrm{~min}$. Then 2-iodotoluene (127 $\mu \mathrm{L}, 1.00 \mathrm{mmol}, 1.0$ equiv) and $\mathrm{Pd}_{2}(\mathrm{dba})_{3} \cdot \mathrm{CHCl}_{3}(26 \mathrm{mg}, 0.025 \mathrm{mmol}, 2.5 \mathrm{~mol} \%$ ) were added to the solution sequentially. The flask was purged with Ar, and the reaction mixture was stirred at room temperature under Ar atmosphere for $4 \mathrm{~h}$. Then, the reaction mixture was passed through thin layer of silica gel (approximately $1 \mathrm{~cm}$ ) followed by a wash of EtOAc $(100 \mathrm{~mL})$. The dark-brown filtrate was added silica gel $(1 \mathrm{~g})$ and was concentrated under reduced pressure. The crude product adsorbed on silica gel was purified using flash chromatography (silica gel (75 $\mathrm{g})$, hexane/EtOAc, 40/1) and diffusion pump distillation to afford $279.2 \mathrm{mg}(85 \%)$ of $\mathbf{1 6 e}$ as a colorless, viscous liquid.

Data for 16e:

b.p.: $128^{\circ} \mathrm{C}(\mathrm{ABT})$ at $9.0 \times 10^{-5} \mathrm{mmHg}$

${ }^{1} \mathrm{H}$ NMR: $\quad\left(500 \mathrm{MHz}, \mathrm{CDCl}_{3}\right)$

7.20-7.17 (m, 1 H, HC(12)), 7.16-7.11 (m, 3 H, HC(Aryl)), 6.37 (s, 1 H, HC(6)), 4.25-4.19 (m, 4 H, $\left.2 \times \mathrm{H}_{2} \mathrm{C}\left(2^{\prime}\right)\right), 3.23$ (ddd, $1 \mathrm{H}, J=15.9$, 2.3, 2.3, $\left.\mathrm{H}_{3} \mathrm{C}(2)\right)$, 3.032.99 (m, 1 H, HC(4)), 3.01 (d, 1 H, $J=16.1$, HC(2)), 2.68 (ddd, $1 \mathrm{H}, J=13.3,8.2$, 1.4, $\mathrm{HC}(5)), 2.22$ (s, $\left.3 \mathrm{H}, \mathrm{H}_{3} \mathrm{C}(13)\right), 1.84$ (dd, $\left.1 \mathrm{H}, J=13.3,7.2, \mathrm{HC}(5)\right), 1.28$ (t, 3 $\left.\mathrm{H}, J=7.1, \mathrm{H}_{3} \mathrm{C}\left(3^{\prime}\right)\right), 1.28$ (t, $\left.3 \mathrm{H}, J=7.1, \mathrm{H}_{3} \mathrm{C}\left(3^{\prime}\right)\right), 0.83$ (d, $3 \mathrm{H}, J=6.8$, $\left.\mathrm{H}_{3} \mathrm{C}(12)\right)$. 
${ }^{13} \mathrm{C}$ NMR: $\quad\left(126 \mathrm{MHz}, \mathrm{CDCl}_{3}\right)$

172.2 (C(1')), 172.0 (C(1')), 146.7 (C(3)), 137.5 (C(7)), 136.2 (C(8)), 129.8 (C(Aryl)), 128.5 (C(12)), 126.8 (C(Aryl)), 125.7 (C(Aryl)), 121.9 (C(6)), 61.7 (C(2’)), 61.7 (C(2’)), 58.9 (C(1)), 42.5 (C(5)), 42.4 (C(2)), 34.6 (C(4)), 20.1 (C(13)), 19.7 (C(14)), 14.3 (C(3’)), 14.3 (C(3’)).

$\underline{\text { IR: (neat) }}$

3464 (w), 2980 (m), 1372 (s), 1459 (m), 1366 (s), 1244 (s), 1176 (m), 1098 (m), 1066 (m), 1034 (m), 1178 (s), 1098 (m), 1066 (m), 1034 (s), 863 (s), 737 (m).

LRMS: (EI):

105 (43.9), 183 (87.0), 256 (100.0), 330 (32.7, [M] $\left.]^{+}\right)$.

HRMS: (EI, [M] $\left.]^{+}\right)$:

calcd.: 330.183110

found: 330.182732

Analysis: $\mathrm{C}_{20} \mathrm{H}_{26} \mathrm{O}_{5} \quad(330.42)$

calcd.: C, 72.70; H, 7.93.

found: C, 72.42; $\quad \mathrm{H}, 7.97$.

$\underline{\mathrm{R}}_{\mathrm{f}}: \quad 0.54$ (silica gel, hexane/EtOAc, 5/1, UV)

$\underline{t_{\mathrm{R}}}: \quad 3.183 \mathrm{~min}$ (Agilent Zorbax 300SB-C8, 100\% MeCN (1 mL/min))

\section{MOM-Protection of 3-Iodobenzyl Alcohol. Preparation of 3-Iodobenzyl Methoxymethyl Ether (18).}<smiles>OCc1cccc(I)c1</smiles>
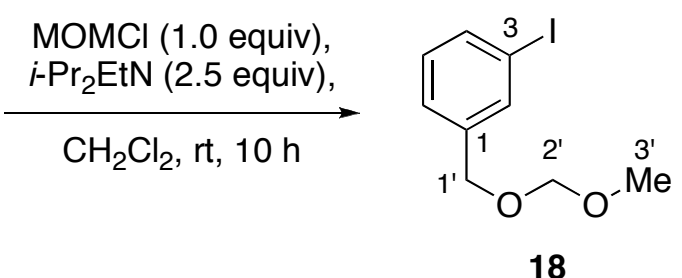

3-Iodobenzyl alcohol (0.64 mL, $5.0 \mathrm{mmol}, 1.0$ equiv) in a $25-\mathrm{mL}$, flame-drided roundbottomed flask equipped with a gas inlet adaptor and a magnetic stirrer was dissolved in $5 \mathrm{~mL}$ of $\mathrm{CH}_{2} \mathrm{Cl}_{2}$. This solution was cooled in an ice bath before it was treated with $i-\operatorname{Pr}_{2} \mathrm{EtN}(8.7 \mathrm{~mL}, 50.0$ mmol, 10.0 equiv). The reaction mixture was stirred for $1 \mathrm{~h}$ in the ice bath under Ar, and subsequently, $\mathrm{MOMCl}(0.95 \mathrm{~mL}, 50.0 \mathrm{mmol}, 10.0$ equiv) was added dropwise in the course of 3 min. The evolution of a white smoke was observed during the addition. The reaction mixture 
remained stirring in the ice bath under Ar or 20 min after the addition had completed before the ice bath was removed. The reaction mixture was allowed to warm up to room temperature and it was stirred at room temperature under Ar for $9 \mathrm{~h}$ and $40 \mathrm{~min}$. Then, the reaction mixture was poured into a $250-\mathrm{mL}$ separatory funnel containing $20 \mathrm{~mL}$ of water. The aqueous layer was extracted with $\mathrm{Et}_{2} \mathrm{O}(3 \times 20 \mathrm{~mL})$. The combined organic layers were washed with $20 \mathrm{~mL}$ of saturated $\mathrm{NH}_{4} \mathrm{Cl}$ aqueous solution followed by $20 \mathrm{~mL}$ of brine, dried over anhydrous $\mathrm{MgSO}_{4}$, and were filtered. The filtrate was concentrated under reduced pressure. The resulting crude product was purified by flash chromatography (silica gel $(100 \mathrm{~g})$, hexane/EtOAc $=80 / 1(1 \mathrm{~L})$, 40/1 $(900 \mathrm{~mL}))$ and Kugelrohr distillation to afford $1.323 \mathrm{~g}(95 \%)$ of $\mathbf{1 8}$ as a colorless liquid.

\section{Data for 18:}

b.p.: $\quad 175^{\circ} \mathrm{C}(\mathrm{ABT})$ at $0.8 \mathrm{mmHg}$

${ }^{1} \mathrm{H}$ NMR: $\quad\left(500 \mathrm{MHz}, \mathrm{CDCl}_{3}\right)$

7.74 (s, $1 \mathrm{H}, \mathrm{HC}(2)), 7.64$ (d, $1 \mathrm{H}, J=8.0, \mathrm{HC}(4)), 7.32(\mathrm{~d}, 1 \mathrm{H}, J=7.7, \mathrm{HC}(6))$,

7.10 (t, $1 \mathrm{H}, J=7.8, \mathrm{HC}(5)), 4.71$ (s, 2 H, $\left.\mathrm{H}_{2} \mathrm{C}\left(2^{\prime}\right)\right)$ ), 4.55 (s, $\left.2 \mathrm{H}, \mathrm{H}_{2} \mathrm{C}\left(1^{\prime}\right)\right), 3.42$

(s, $\left.3 \mathrm{H}, \mathrm{HC}\left(3^{\prime}\right)\right)$.

${ }^{13} \mathrm{C} \mathrm{NMR}: \quad\left(126 \mathrm{MHz}, \mathrm{CDCl}_{3}\right)$

$140.5(\mathrm{C}(3)), 136.9(\mathrm{C}(2)$ or $\mathrm{C}(4)), 136.9(\mathrm{C}(2)$ or $\mathrm{C}(4)), 130.4(\mathrm{C}(5)), 127.1$ (C(6)), $96.0\left(\mathrm{C}\left(2^{\prime}\right)\right)$, $94.6(\mathrm{C}(1)), 68.4\left(\mathrm{C}\left(1^{\prime}\right)\right), 55.6\left(\mathrm{C}\left(3^{\prime}\right)\right)$.

IR: (neat)

2944 (s), 2884 (s), 1594 (m), 1567 (s), 1471 (m), 1423 (m), 1376 (m), 1210 (m), $1150(\mathrm{~s}), 1106(\mathrm{~s}), 1048(\mathrm{~s}), 918(\mathrm{~m}), 776(\mathrm{~s})$.

LRMS: (EI):

$278.0\left(62.3,[\mathrm{M}]^{+}\right), 246$ (14.5), 218 (100.0), 217 (87.9), 119 (16.8), 91 (78.1), 76 (9.3), 63 (13.4).

HRMS: (EI, $\left.[\mathrm{M}]^{+}\right)$:

calcd.: 277.980382

found: 277.980448

Analysis: $\mathrm{C}_{9} \mathrm{H}_{11} \mathrm{O}_{2} \mathrm{I} \quad$ (278.09)

calcd.: C, 38.87; $\quad$ H, 3.99.

found: C, 38.70; $\quad \mathrm{H}, 3.85$.

$\underline{\mathrm{R}}_{\mathrm{f}}: \quad 0.62$ (silica gel, hexane/EtOAc, 5/1, UV) 
$\underline{t_{\mathrm{R}}}: \quad 2.99 \mathrm{~min}$ (Agilent Zorbax 300SB-C8, 100\% MeCN (1 mL/min))

\section{Cross-Coupling Reaction of 6 with 3-Iodobenzyl Methoxymethyl Ether (18). Preparation of} Diethyl (Z)-3-(2-Methylbenzylidene)-4-methylcyclopentane-1,1-dicarboxylate (16f).
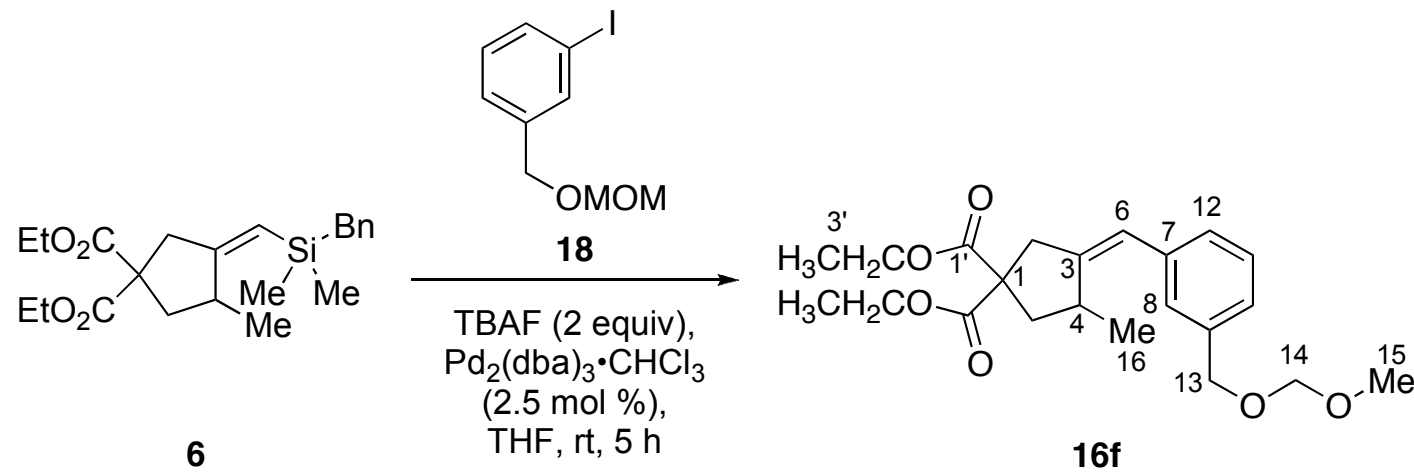

$16 f$

Alkylidenylsilane 6 (427 mg, $1.10 \mathrm{mmol}, 1.1$ equiv) in a 5-mL, round-bottomed flask with a magnetic stir bar and fitted with a gas inlet adaptor, was dissolved in a solution of $\mathrm{TBAF} \cdot 3 \mathrm{H}_{2} \mathrm{O}(1.0 \mathrm{M}$ in THF, $2.0 \mathrm{~mL}, 2.0 \mathrm{mmol}, 2.0$ equiv) and the resulting light-yellow solution was stirred at room temperature under $\mathrm{Ar}$ for approximately $3 \mathrm{~min}$. Then methoxymethyl 3-iodobenzyl ether (18) $\left(292 \mathrm{mg}, 1.00 \mathrm{mmol}, 1.0\right.$ equiv) and $\mathrm{Pd}_{2}(\mathrm{dba})_{3} \cdot \mathrm{CHCl}_{3}$ (26 mg, $0.025 \mathrm{mmol}, 2.5 \mathrm{~mol} \%$ ) were added to the solution sequentially. The flask was purged with Ar, and the reaction mixture was stirred at room temperature under Ar atmosphere for $5 \mathrm{~h}$. Then, the reaction mixture was passed through thin layer of silica gel (approximately $1 \mathrm{~cm}$ ) followed by a wash of EtOAc $(100 \mathrm{~mL})$. The dark-brown filtrate was added silica gel $(1 \mathrm{~g})$ and was concentrated under reduced pressure. The crude product adsorbed on silica gel was purified using flash chromatography (silica gel (45 g), hexane/EtOAc, 40/1 (250 mL), 30/1 (250 mL), 20/1 (250 mL), 10/1 (500 mL), 5/1(250 mL)), reverse phase flash chromatography (reverse phase silica gel $\left.(30 \mathrm{~g}), \mathrm{MeCN} / \mathrm{H}_{2} \mathrm{O}, 1 / 1(250 \mathrm{~mL}), 2 / 1(250 \mathrm{~mL})\right)$, and diffusion pump distillation to afford $318 \mathrm{mg}(81 \%)$ of $\mathbf{1 6 f}$ as a colorless, viscous liquid.

\section{Data for 16f:}

b.p.: $\quad 167^{\circ} \mathrm{C}(\mathrm{ABT})$ at $9.0 \times 10^{-5} \mathrm{mmHg}$

${ }^{1} \mathrm{H}$ NMR: $\quad\left(500 \mathrm{MHz}, \mathrm{CDCl}_{3}\right)$

$7.29(\mathrm{t}, 1 \mathrm{H}, J=7.6, \mathrm{HC}(11)), 7.26(\mathrm{~s}, 1 \mathrm{H}, \mathrm{HC}(8)), 7.22(\mathrm{~d}, 1 \mathrm{H}, J=7.6$, 
$\mathrm{HC}(10)), 7.18$ (d, $1 \mathrm{H}, J=7.3, \mathrm{HC}(12)), 6.34$ (s, $1 \mathrm{H}, \mathrm{HC}(6)), 4.17$ (s, $2 \mathrm{H}$, $\left.\mathrm{H}_{2} \mathrm{C}(14)\right), 4.58$ (s, $\left.2 \mathrm{H}, \mathrm{H}_{2} \mathrm{C}(13)\right)$, 4.25-4.18 (m, $4 \mathrm{H}, 2 \times \mathrm{H}_{2} \mathrm{C}\left(2^{\prime}\right.$ )), 3.42 (s, $3 \mathrm{H}$, $\left.\mathrm{H}_{3} \mathrm{C}(15)\right)$, 3.30-3.27 (m, $\left.1 \mathrm{H}, \mathrm{HC}(4)\right), 3.28$ (dd, $\left.2 \mathrm{H}, J=16.1,2.2, \mathrm{H}_{2} \mathrm{C}(2)\right), 2.97$ (d, $1 \mathrm{H}, J=16.1, \mathrm{HC}(2)), 2.74$ (dd, $1 \mathrm{H}, J=13.3,8.2, \mathrm{HC}(5)), 1.87$ (dd, $1 \mathrm{H}, J=$ 13.3, 6.0, $\left.\mathrm{H}_{3} \mathrm{C}(5)\right), 1.28$ (t, $\left.3 \mathrm{H}, J=7.0, \mathrm{H}_{3} \mathrm{C}\left(3^{\prime}\right)\right)$ ), 1.25 (t, $3 \mathrm{H}, J=7.0, \mathrm{H}_{3} \mathrm{C}\left(3^{\prime}\right)$ ), $1.07\left(\mathrm{~d}, 3 \mathrm{H}, J=7.1, \mathrm{H}_{3} \mathrm{C}(16)\right)$.

${ }^{13} \mathrm{C}$ NMR: $\quad\left(126 \mathrm{MHz}, \mathrm{CDCl}_{3}\right)$

172.2 (C(1')), 171.9 (C(1')), 147.3 (C(3)), 137.9 (C(7)), 128.5 (C(Aryl)), 128.1 (C(Aryl)), 127.7 (C(Aryl)), 126.0 (C(10)), 122.5 (C(6)), 95.8 (C(14)), 69.3 (C(13)), 61.7 (C(2')), 61.7 (C(2’)), 58.4 (C(1)), 55.5 (C(15)), 43.1 (C(2)), 42.6 (C(5)), 34.7 (C(4)), 19.7 (C(16)), 14.2 (C(3’)).

IR: (neat)

3459 (w), 2980 (m), 1732 (s), 1464 (w), 1448 (w), 1246 (m), 1150 (m), 1104 (m), 1049 (m), 918 (w), 861 (w), 785 (w).

LRMS: (EI):

$390\left(0.9,[\mathrm{M}]^{+}\right), 372$ (5.3), 328 (39.9), 254 (100.0), 200 (17.5), 181 (47.2), 154 (30.3), 119 (67.9), 91 (34.3).

HRMS: $\left(\mathrm{EI},[\mathrm{M}]^{+}\right)$:

calcd.: 390.205576

found: 390.204924

Analysis: $\mathrm{C}_{22} \mathrm{H}_{30} \mathrm{O}_{6} \quad(390.00)$

calcd.: C, 67.67; H, 7.74.

found: C, 67.62; $\quad H, 7.75$.

$\underline{\mathrm{R}}_{\mathrm{f}}: \quad 0.30$ (silica gel, hexane/EtOAc, 5/1, UV)

$\underline{t_{\mathrm{R}}}: \quad 3.08 \mathrm{~min}$ (Agilent Zorbax 300SB-C8, 100\% MeCN (1 mL/min)) 


\section{Cross-Coupling Reaction of 6 with 1-Iodonaphthalene. Preparation of Diethyl (Z)-3-(1- Naphthylidene)-4-methylcyclopentane-1,1-dicarboxylate (16g).}
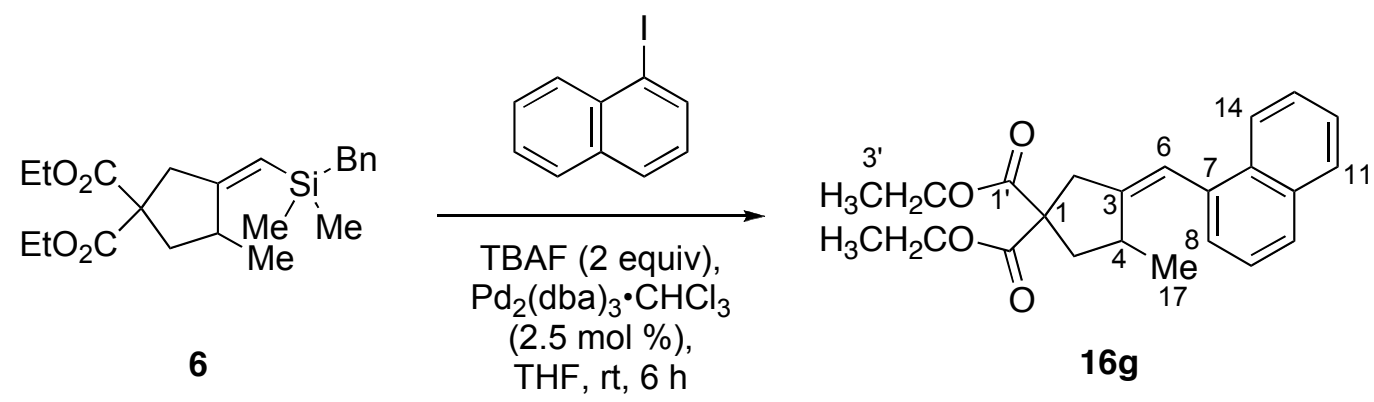

Alkylidenylsilane 6 (426 mg, $1.10 \mathrm{mmol}, 1.1$ equiv) in a 5-mL, round-bottomed flask with a magnetic stir bar and fitted with a gas inlet adaptor, was dissolved in a solution of $\mathrm{TBAF} \cdot 3 \mathrm{H}_{2} \mathrm{O}(1.0 \mathrm{M}$ in THF, $2.0 \mathrm{~mL}, 2.0 \mathrm{mmol}, 2.0$ equiv) and the resulting light-yellow solution was stirred at room temperature under $\mathrm{Ar}$ for approximately $3 \mathrm{~min}$. Then 1iodonaphthalene $\left(146 \mu \mathrm{L}, 1.00 \mathrm{mmol}, 1.0\right.$ equiv) and $\mathrm{Pd}_{2}\left(\mathrm{dba}_{3} \cdot \mathrm{CHCl}_{3}(26 \mathrm{mg}, 0.025 \mathrm{mmol}, 2.5\right.$ mol \%) were added to the solution sequentially. The flask was purged with Ar, and the reaction mixture was stirred at room temperature under Ar atmosphere for $6 \mathrm{~h}$. Then, the reaction mixture was passed through thin layer of silica gel (approximately $1 \mathrm{~cm}$ ) followed by a wash of EtOAc $(100 \mathrm{~mL})$. The dark-brown filtrate was added silica gel $(1 \mathrm{~g})$ and was concentrated under reduced pressure. The crude product adsorbed on silica gel was purified using flash chromatography (silica gel (45 g), hexane/EtOAc, 80/1 (250 mL), 40/1 (1 L)), reverse phase chromatography (first column: reverse phase silica gel $(20 \mathrm{~g}), \mathrm{MeCN} / \mathrm{H}_{2} \mathrm{O}, 1 / 1(250 \mathrm{~mL}), 2 / 1(500 \mathrm{~mL})$, second column: reverse phase silica gel $(20 \mathrm{~g}), \mathrm{MeCN} / \mathrm{H}_{2} \mathrm{O}, 1 / 1(500 \mathrm{ml}), 2 / 1(125 \mathrm{~mL}), 3 / 1(125 \mathrm{~mL})$, 4/1 (250 mL)) and diffusion pump distillation to afford $330 \mathrm{mg}(93 \%)$ of $\mathbf{1 6 g}$ as a light-yellow, viscous liquid.

\section{Data for 16g:}

b.p.: $\quad 161{ }^{\circ} \mathrm{C}(\mathrm{ABT})$ at $9.0 \times 10^{-5} \mathrm{mmHg}$

茾 NMR: $\quad\left(500 \mathrm{MHz}, \mathrm{CDCl}_{3}\right)$

7.98-7.96 (m, $1 \mathrm{H}, \mathrm{HC}(14))$, 7.85-7.84 (m, $1 \mathrm{H}, \mathrm{HC}(11)), 7.75$ (d, $1 \mathrm{H}, J=8.1$, $\mathrm{HC}(10))$ ) 7.50-7.47 (m, $2 \mathrm{H}, \mathrm{HC}(12), \mathrm{HC}(13)), 7.43$ (t, $1 \mathrm{H}, J=7.6, \mathrm{HC}(9)), 7.37$ $(\mathrm{d}, 1 \mathrm{H}, J=7.5, \mathrm{HC}(8)), 6.81(\mathrm{~s}, 1 \mathrm{H}, \mathrm{HC}(6)), 4.28$ (q, $\left.2 \mathrm{H}, J=7.3, \mathrm{H}_{2} \mathrm{C}\left(2^{\prime}\right)\right)$, 4.27-4.21 (m, $2 \mathrm{H}, \mathrm{H}_{2} \mathrm{C}\left(2^{\prime}\right)$ ), 3.33 (d, $1 \mathrm{H}, J=16.1, \mathrm{HC}(2)$ ), 3.17 (d, $1 \mathrm{H}, J=15.8$, HC(2)), 3.05-2.99 (m, 1 H, HC(4)), 2.68 (dd, 1 H, $J=13.2,8.1$, HC(5)), 1.87 (dd, 
$\left.1 \mathrm{H}, J=13.2,7.3, \mathrm{H}_{3} \mathrm{C}(5)\right), 1.32$ (t, $\left.3 \mathrm{H}, J=7.2, \mathrm{H}_{3} \mathrm{C}\left(3^{\prime}\right)\right)$, 1.30 (t, $3 \mathrm{H}, J=7.1$, $\left.\mathrm{H}_{3} \mathrm{C}\left(3^{\prime}\right)\right), 0.73\left(\mathrm{~d}, 3 \mathrm{H}, J=7.8, \mathrm{H}_{3} \mathrm{C}(17)\right)$.

${ }^{13} \mathrm{C} \mathrm{NMR:} \quad\left(126 \mathrm{MHz}, \mathrm{CDCl}_{3}\right)$

172.2 (C(1')), 172.1 (C(1')), 148.7 (C(3)), 135.6 (C(7)), 133.7 (C(16)), 131.9 (C(15)), 128.5 (C(14)), 127.2 (C(11)), 125.9 (C(Aryl)), 125.6 (C(Aryl)), 125.3 (C(Aryl)), 120.8 (C(8)), 61.8 (C(6)), 61.7 (C(2’)), 61.7 (C(2’)), 59.0 (C(1)), 42.4 $(\mathrm{C}(2)$ or $\mathrm{C}(5)), 42.4(\mathrm{C}(2)$ or $\mathrm{C}(5)), 35.0(\mathrm{C}(4)), 19.8$ (C(17)), $14.3\left(\mathrm{C}\left(3^{\prime}\right)\right), 14.2$ $\left(\mathrm{C}\left(3^{\prime}\right)\right)$.

$\underline{\text { IR: (neat) }}$

3462 (w), 2980 (m), 1371 (s), 1447 (m), 1366 (m), 1245 (s), 1178 (s), 1098 (m), $1066(\mathrm{~m}), 1032(\mathrm{~m}), 862(\mathrm{w}), 782(\mathrm{~m}), 772(\mathrm{~m})$.

LRMS: (EI):

141 (48.0), 203 (24.5), 292 (100.0), $366\left(56.4,[\mathrm{M}]^{+}\right)$.

HRMS: $\left(\mathrm{EI},[\mathrm{M}]^{+}\right)$:

calcd.: 366.184447

found: 366.183812

Analysis: $\mathrm{C}_{20} \mathrm{H}_{26} \mathrm{O}_{5} \quad(366.45)$

calcd.: C, 75.38; H, 7.15.

found: C, 75.15; $\mathrm{H}, 7.11$.

$\underline{\mathrm{R}}_{\mathrm{f}}: \quad 0.55$ (silica gel, hexane/EtOAc, 5/1, UV)

$\underline{t_{\mathrm{R}}}: \quad 3.133 \mathrm{~min}$ (Agilent Zorbax 300SB-C8, 100\% MeCN (1 mL/min))

Cross-Coupling Reaction of 7 with Ethyl 4-Iodobenzoate. Preparation of $N$-Benzyl-(Z)-3-(4ethoxycarbonylbenzylidene)-4-methylpyrrolidine (19a).
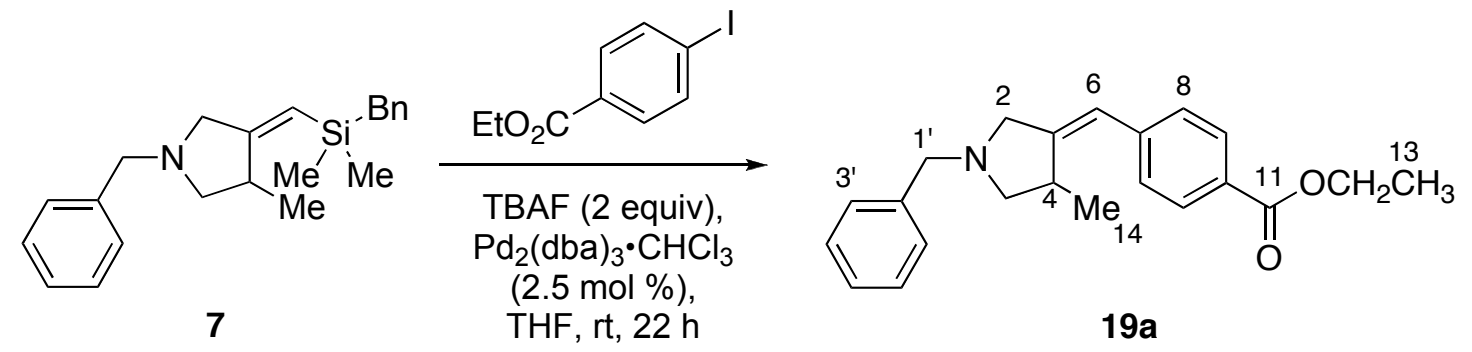

Alkylidenylsilane 7 (370 mg, $1.10 \mathrm{mmol}, 1.1$ equiv) in a 10-mL, round-bottomed flask with a magnetic stir bar and fitted with a gas inlet adaptor, was dissolved in a solution of 
TBAF $• 3 \mathrm{H}_{2} \mathrm{O}(1.0 \mathrm{M}$ in THF, $2.0 \mathrm{~mL}, 2.0 \mathrm{mmol}, 2.0$ equiv) and the resulting light-yellow solution was stirred at room temperature under Ar for approximately $3 \mathrm{~min}$. Then ethyl 4iodobenzoate (274 mg, $1.00 \mathrm{mmol}, 1.0$ equiv) and $\mathrm{Pd}_{2}(\mathrm{dba})_{3} \cdot \mathrm{CHCl}_{3}(26 \mathrm{mg}, 0.025 \mathrm{mmol}, 2.5$ mol \%) were added to the solution sequentially. The flask was purged with Ar, and the reaction mixture was stirred at room temperature under Ar atmosphere for $22 \mathrm{~h}$. Then, the reaction mixture was passed through thin layer of silica gel (approximately $1 \mathrm{~cm}$ ) followed by a wash of EtOAc $(100 \mathrm{~mL})$. The dark-brown filtrate was added silica gel $(1 \mathrm{~g})$ and was concentrated under reduced pressure. The crude product adsorbed on silica gel was purified using flash chromatography (first column: silica gel (45 g), hexane/EtOAc, 60/1 (250 mL), 40/1 (250 mL), 30/1 (250 mL), 20/1 (250 mL), 10/1 (1 L), second column: silica gel (45 g), hexane/EtOAc, 60/1 $(250 \mathrm{~mL}), 40 / 1(250 \mathrm{~mL}), 30 / 1(250 \mathrm{~mL}), 20 / 1(500 \mathrm{~mL}), 5 / 1(750 \mathrm{~mL}))$ to afford $254.6 \mathrm{mg}$ (72\%) of 19a as a yellow, viscous liquid. Product 19a was unable to be obtained analytically pure. Analytical sample obtained by further purification using flash chromagraphy (silica gel (30 g), hexane/EtOAc, 40/1 (500 mL), 20/1 (500 mL), 5/1 (500 mL)).

\section{Data for 19a:}

\section{${ }^{1} \mathrm{H}$ NMR: $\quad\left(500 \mathrm{MHz}, \mathrm{CDCl}_{3}\right)$}

$8.30(\mathrm{~d}, 2 \mathrm{H}, J=8.3, \mathrm{HC}(9)), 7.38-7.32$ (m, $\left.4 \mathrm{H}, J=7.3,2 \times \mathrm{HC}\left(3^{\prime}\right), 2 \times \mathrm{HC}\left(4^{\prime}\right)\right)$, 7.34 (d, $2 \mathrm{H}, J=8.3,2 \times \mathrm{HC}(8)), 7.27$ (t, $\left.1 \mathrm{H}, J=6.0, \mathrm{HC}\left(5^{\prime}\right)\right), 6.31$ (d, $1 \mathrm{H}, J=$ 1.5, $\mathrm{HC}(6)), 4.37$ (q, $\left.2 \mathrm{H}, J=7.1, \mathrm{H}_{2} \mathrm{C}(12)\right), 3.66\left(\mathrm{~d}, 1 \mathrm{H}, J=12.7, \mathrm{HC}\left(1^{\prime}\right)\right), 3.63$ (d, $\left.1 \mathrm{H}, J=12.9, \mathrm{HC}\left(1^{\prime}\right)\right), 3.44$ (d, $\left.2 \mathrm{H}, J=13.4, \mathrm{HC}(2)\right), 3.33-3.25$ (m, $1 \mathrm{H}$, HC(4)), 3.27 (d, $1 \mathrm{H}, J=14.6, \mathrm{HC}(2)$ ), 2.89 (dd, $1 \mathrm{H}, J=8.7,7.0, \mathrm{HC}(5)$ ), 2.46 (dd, $1 \mathrm{H}, J=8.8,4.4$, $\mathrm{HC}(5)), 1.39$ (t, $\left.3 \mathrm{H}, J=7.1, \mathrm{H}_{3} \mathrm{C}(13)\right), 1.10$ (d, $3 \mathrm{H}, J=$ $\left.6.8, \mathrm{H}_{3} \mathrm{C}(14)\right)$.

${ }^{13} \mathrm{C}$ NMR: $\quad\left(126 \mathrm{MHz}, \mathrm{CDCl}_{3}\right)$

166.7 (C(11)), 150.3 (C(2')), 142.3 (C(10)), 139.0 (C(7)), 129.8 (C(9)), 128.9 (C(aryl)), 128.5 (C(aryl)), 128.2 (C(aryl)), 128.1 (C(aryl)), 127.2 (C(aryl)), 120.1 $(\mathrm{C}(6)), 63.0(\mathrm{C}(5)), 61.8(\mathrm{C}(2)), 61.0(\mathrm{C}(12)), 60.6\left(\mathrm{C}\left(1^{\prime}\right)\right), 35.8(\mathrm{C}(3)), 17.9$ (C(14)), $14.6(\mathrm{C}(13))$.

IR: (neat)

3410 (w), 2975 (m), 2930 (m), 2790 (m), 1714 (s), 1606 (s), 1453 (m), 1367 (s), 1275 (s), 1180 (s), 1108 (s), 1121 (m), 876 (m), 741 (m), 700 (s). 
LRMS: (CI):

$336\left(100.0,[\mathrm{M}+\mathrm{H}]^{+}\right), 290$ (5.6), 258 (3.2), 244 (1.8), 91 (6.7), 86 (7.9), 84 (12.8).

HRMS: $\left(\mathrm{CI},[\mathrm{M}+\mathrm{H}]^{+}\right)$:

calcd.: 336.1937

found: 336.1970

$\underline{\mathrm{R}}_{\mathrm{f}}: \quad 0.33$ (silica gel, hexane/EtOAc, 5/1, UV)

$\underline{t_{\mathrm{R}}}: 4.45 \min$ (Agilent Zorbax $\mathrm{Rx}-\mathrm{C} 8, \mathrm{MeCN} / \mathrm{H}_{2} \mathrm{O}=1 / 1\left(\mathrm{H}_{2} \mathrm{O}\right.$ contained $0.1 \%$ of HOAc and $0.1 \%$ of TFA) $(1 \mathrm{~mL} / \mathrm{min}))$

Cross-Coupling Reaction of 7 with 4-Iodoanisole. Preparation of $N$-Benzyl-(Z)-3-(4methoxylbenzylidene)-4-methylpyrrolidine (19b).

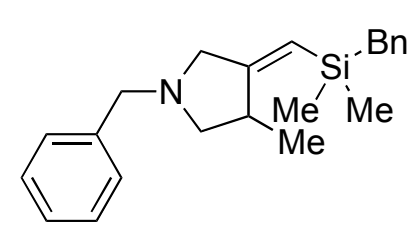

7

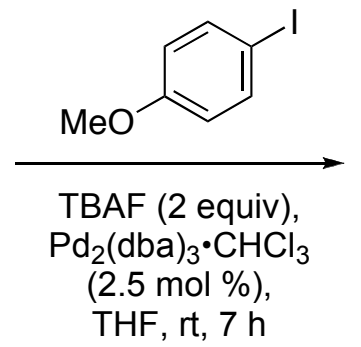

THF, rt, $7 \mathrm{~h}$

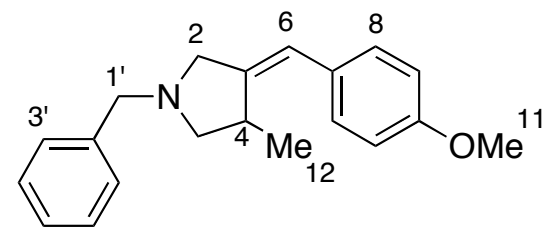

$19 b$

Alkylidenylsilane 7 (369 mg, $1.10 \mathrm{mmol}, 1.1$ equiv) in a 10-mL, round-bottomed flask with a magnetic stir bar and fitted with a gas inlet adaptor, was dissolved in a solution of $\mathrm{TBAF} \cdot 3 \mathrm{H}_{2} \mathrm{O}(1.0 \mathrm{M}$ in THF, $2.0 \mathrm{~mL}, 2.0 \mathrm{mmol}, 2.0$ equiv) and the resulting light-yellow solution was stirred at room temperature under Ar for approximately $3 \mathrm{~min}$. Then 4 -iodoanisole (234 mg, $1.00 \mathrm{mmol}, 1.0$ equiv) and $\mathrm{Pd}_{2}(\mathrm{dba})_{3} \cdot \mathrm{CHCl}_{3}(26 \mathrm{mg}, 0.025 \mathrm{mmol}, 2.5 \mathrm{~mol} \%$ ) were added to the solution sequentially. The flask was purged with Ar, and the reaction mixture was stirred at room temperature under Ar atmosphere for $7 \mathrm{~h}$. Then, the reaction mixture was passed through thin layer of silica gel (approximately $1 \mathrm{~cm}$ ) followed by a wash of EtOAc $(100 \mathrm{~mL})$. The dark-brown filtrate was added silica gel $(1 \mathrm{~g})$ and was concentrated under reduced pressure. The crude product adsorbed on silica gel was purified using flash chromatography (first column: silica gel (45 g), hexane/EtOAc, 60/1 (250 mL), 40/1 (500 mL), 30/1 (250 mL), 20/1 (250 mL), 10/1 (1 L), second column: silica gel (45 g), hexane/Et ${ }_{2} \mathrm{O}, 80 / 1$ (250 mL), 60/1 (250 mL), 40/1 $(250 \mathrm{~mL}), 10 / 1(500 \mathrm{~mL}), 5 / 1(250 \mathrm{~mL}))$ to afford $265 \mathrm{mg}(90 \%)$ of 19b as a yellow solid. Product 19b was unable to be obtained analytically pure. 


\section{Data for 19b:}

m.p.: $\quad 51-53{ }^{\circ} \mathrm{C}$

${ }^{1} \mathrm{H}$ NMR: $\quad\left(500 \mathrm{MHz}, \mathrm{CDCl}_{3}\right)$

7.39 (d, $\left.2 \mathrm{H}, J=7.3,2 \times \mathrm{HC}\left(3^{\prime}\right)\right)$ ), 7.34 (t, $\left.2 \mathrm{H}, J=7.5,2 \times \mathrm{HC}\left(4^{\prime}\right)\right), 7.28$ (d, 2 H, $\left.J=7.3, \mathrm{HC}\left(5^{\prime}\right)\right), 7.26(\mathrm{~d}, 2 \mathrm{H}, J=8.8,2 \times \mathrm{HC}(8)), 6.86(\mathrm{~d}, 2 \mathrm{H}, J=8.8,2 \times$ $\mathrm{HC}(9)), 6.23$ (s, $1 \mathrm{H}, \mathrm{HC}(6)), 3.81$ (s, $\left.3 \mathrm{H}, \mathrm{H}_{3} \mathrm{C}(11)\right), 3.67$ (d, $1 \mathrm{H}, J=12.7$, HC(1')), 3.63 (d, 1 H, $\left.J=12.7, \mathrm{HC}\left(1^{\prime}\right)\right), 3.42$ (d, 2 H, $\left.J=13.2, \mathrm{HC}(2)\right), 3.27-3.23$ (m, $1 \mathrm{H}, \mathrm{HC}(4)), 3.25$ (d, $1 \mathrm{H}, J=13.4, \mathrm{HC}(2)), 2.88$ (dd, $1 \mathrm{H}, J=7.8,7.8$, $\mathrm{HC}(5)), 2.46$ (dd, $1 \mathrm{H}, J=8.7,4.3, \mathrm{HC}(5)), 1.10$ (d, $3 \mathrm{H}, J=6.8, \mathrm{H}_{3} \mathrm{C}(12)$ ).

\section{${ }^{13} \mathrm{C} \mathrm{NMR:} \quad\left(126 \mathrm{MHz}, \mathrm{CDCl}_{3}\right)$}

158.1 (C(3)), 145.2 (C(2’)), 139.3 (C(7)), 130.5 (C(10)), 129.5 (C(5')), 129.0 (C(3’)), 128.5 (C(4’)), 127.2 (C(8)), 120.1 (C(6)), 113.9 (C(9)), 63.2 (C(5)), 61.8 (C(2)), 60.7 (C(1')), 55.4 (C(11)), 35.5 (C(4)), 17.9 (C(13)).

$\underline{\text { IR: (neat) }}$ 3029 (w), 2960 (m), 2929 (m), 2787 (m), 2360 (w), 1608 (s), 1511 (s), 1544 (s), 1454 (m), 1250 (s), 1178 (s), 1126 (m), 1036 (s), 865 (m), 822 (m), 743 (m), 700 (s).

LRMS: (EI): $293\left(100.0,[\mathrm{M}]^{+}\right), 278(8.0), 250$ (24.9), 159 (18.3), 121 (78.3), 91 (87.4).

\section{HRMS: $\left(\mathrm{EI},[\mathrm{M}]^{+}\right)$:}

calcd.: 293.177965

found: 293.177930

$\underline{\mathrm{R}}_{\mathrm{f}}: \quad 0.26$ (silica gel, hexane/EtOAc, 5/1, UV)

$\underline{t_{\mathrm{R}}}: \quad 9.22 \min$ (Agilent Zorbax $\mathrm{Rx}-\mathrm{C} 8, \mathrm{MeCN} / \mathrm{H}_{2} \mathrm{O}=1 / 1\left(\mathrm{H}_{2} \mathrm{O}\right.$ contained $0.1 \%$ of HOAc and $0.1 \%$ of TFA) $(0.5 \mathrm{~mL} / \mathrm{min}))$ 


\section{Cross-Coupling Reaction of 7 with 2-Iodotoluene. Preparation of $N$-Benzyl-(Z)-3-(2-} methylbenzylidene)-4-methylpyrrolidine (19c).

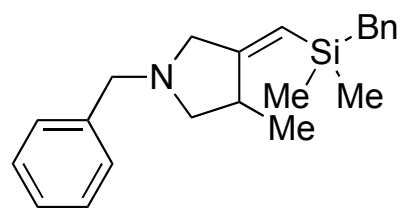

7

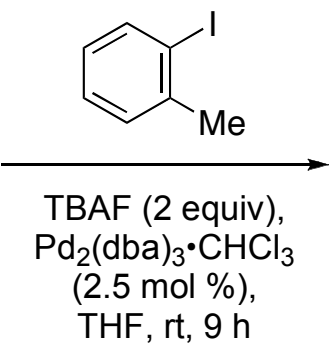

THF, rt, $9 \mathrm{~h}$

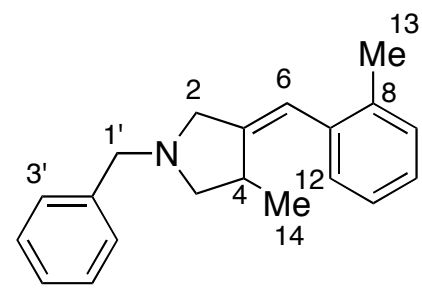

$19 c$

Alkylidenylsilane 7 (369 mg, $1.10 \mathrm{mmol}, 1.1$ equiv) in a 10-mL, round-bottomed flask with a magnetic stir bar and fitted with a gas inlet adaptor, was dissolved in a solution of $\mathrm{TBAF} \cdot 3 \mathrm{H}_{2} \mathrm{O}(1.0 \mathrm{M}$ in THF, $2.0 \mathrm{~mL}, 2.0 \mathrm{mmol}, 2.0$ equiv) and the resulting light-yellow solution was stirred at room temperature under Ar for approximately $3 \mathrm{~min}$. Then 2-iodobenzene (229.0 mg, $1.00 \mathrm{mmol}, 1.0$ equiv) and $\mathrm{Pd}_{2}(\mathrm{dba})_{3} \cdot \mathrm{CHCl}_{3}(26 \mathrm{mg}, 0.025 \mathrm{mmol}, 2.5 \mathrm{~mol} \%$ ) were added to the solution sequentially. The flask was purged with Ar, and the reaction mixture was stirred at room temperature under Ar atmosphere for $9 \mathrm{~h}$. Then, the reaction mixture was passed through thin layer of silica gel (approximately $1 \mathrm{~cm}$ ) followed by a wash of EtOAc $(100 \mathrm{~mL})$. The dark-brown filtrate was added silica gel $(1 \mathrm{~g})$ and was concentrated under reduced pressure. The crude product adsorbed on silica gel was purified using flash chromatography (first column: silica gel (45 g), hexane/EtOAc, 30/1 (250 mL), 20/1 (250 mL), 10/1 (1 L), second column: silica gel (45 g), hexane/Et ${ }_{2} \mathrm{O}, 80 / 1(500 \mathrm{~mL}), 40 / 1(250 \mathrm{~mL}), 20 / 1(250 \mathrm{~mL}), 10 / 1(250 \mathrm{~mL}), 5 / 1$ $(250 \mathrm{~mL}))$ and reverse phase flash chromatography (reverse phase silica gel $(30 \mathrm{~g}), \mathrm{MeCN})$, to afford $237.0 \mathrm{mg}(85 \%)$ of $19 \mathrm{c}$ as a yellow, viscous liquid. Product 19c was unable to be obtained analytically pure.

\section{Data for 19c:}

${ }^{1} \mathrm{H}$ NMR: $\quad\left(500 \mathrm{MHz}, \mathrm{CDCl}_{3}\right)$

7.42 (d, $\left.2 \mathrm{H}, J=7.1,2 \times \mathrm{HC}\left(3^{\prime}\right)\right), 7.37$ (t, $\left.2 \mathrm{H}, J=7.5,2 \times \mathrm{HC}\left(4^{\prime}\right)\right)$, 7.35-7.29 (m, 2 H, HC(12), HC(5')), 7.19-7.15 (m, 3 H, HC(9), HC(10), HC(11)), 6.37 (d, 1 H, $J=1.5, \mathrm{HC}(6)), 3.71\left(\mathrm{~d}, 1 \mathrm{H}, J=12.7, \mathrm{HC}\left(1^{\prime}\right)\right)$, 3.65 (d, $1 \mathrm{H}, J=12.9$, HC(1')), 3.39 (s, $\left.2 \mathrm{H}, \mathrm{H}_{2} \mathrm{C}(2)\right), 3.21-3.17$ (m, $\left.1 \mathrm{H}, \mathrm{HC}(4)\right), 2.96$ (dd, $1 \mathrm{H}, J=8.8,7.1$, $\mathrm{HC}(5)), 2.34$ (dd, $1 \mathrm{H}, J=8.9,5.8, \mathrm{HC}(5)), 2.27$ (s, $\left.3 \mathrm{H}, \mathrm{H}_{3} \mathrm{C}(13)\right), 0.87$ (d, $3 \mathrm{H}, J$ $\left.=6.8, \mathrm{H}_{3} \mathrm{C}(12)\right)$. 


\section{${ }^{13} \mathrm{C} \mathrm{NMR:} \quad\left(126 \mathrm{MHz}, \mathrm{CDCl}_{3}\right)$}

$147.1(\mathrm{C}(3)), 139.1\left(\mathrm{C}\left(2^{\prime}\right)\right), 137.4(\mathrm{C}(7)$ or $\mathrm{C}(8)), 136.2(\mathrm{C}(7)$ or $\mathrm{C}(8)), 129.8$ (C(5')), 129.1 (C(3’)), 128.5 (C(4')), 128.1 (C(9), C(10), C(11) or C(12)), 127.2 (C(9), C(10), C(11) or C(12)), 126.7 (C(9), C(10), C(11) or C(12)), 125.8 (C(9), C(10), C(11) or C(12)), 119.6 (C(6)), 63.1 (C(5)), 61.3 (C(5)), 60.9 (C(1')), 35.3 (C(4)), 20.1 (C(13)), 17.7 (C(14)).

IR: (neat)

3026 (m), 2960 (m), 2925 (m), 2786 (m), 1732 (w), $1676(\mathrm{w}), 1602(\mathrm{w}), 1494$ (m), 1453 (m), 1376 (m), 1323 (m), 1131 (m), 1028 (m), 853 (w), 738 (s), 699 (s).

LRMS: (EI):

$277\left(66.4,[\mathrm{M}]^{+}\right), 262$ (20.3), 234 (4.5), 220 (2.6), 200 (2.6), 186 (12.8), 172 (7.8), 143 (16.5), 128 (14.1), 115 (9.7), 105 (35.4), 91 (100.0), 77 (5.8), 65 (14.0).

HRMS: $\left(\mathrm{EI},[\mathrm{M}]^{+}\right)$:

calcd.: 277.183050

found: 277.183168

$\underline{\mathrm{R}_{\mathrm{f}}}: \quad 0.44$ (silica gel, hexane/EtOAc, 5/1, UV)

$\underline{t_{\mathrm{R}}}: \quad 10.43 \min$ (Agilent Zorbax $\mathrm{Rx}-\mathrm{C} 8, \mathrm{MeCN} / \mathrm{H}_{2} \mathrm{O}=1 / 1\left(\mathrm{H}_{2} \mathrm{O}\right.$ contained $0.1 \%$ of HOAc and $0.1 \%$ of TFA) $(0.5 \mathrm{~mL} / \mathrm{min}))$

\section{Cross-Coupling Reaction of 8 with Ethyl 4-Iodobenzoate. Preparation of (Z)-3-(4-} Ethoxycarbonylbenzylidene)-4-methyltetrahydrofuran (20a).

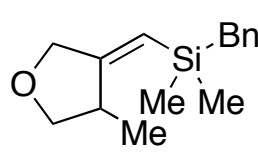

8

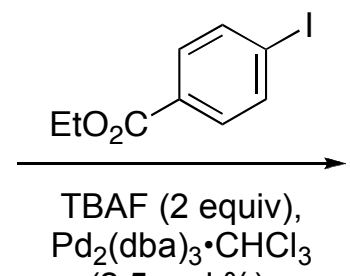

$(2.5 \mathrm{~mol} \%)$,

THF, $24-29^{\circ} \mathrm{C}, 2 \mathrm{~h}$

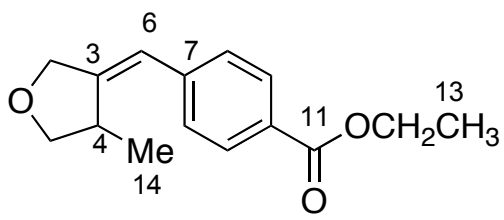

20a

Alkylidenylsilane 8 (270 mg, $1.10 \mathrm{mmol}, 1.1$ equiv) in a 10-mL, two-necked, roundbottomed flask with a magnetic stir bar and fitted with a gas inlet adaptor, was dissolved in a solution of $\mathrm{TBAF} \cdot 3 \mathrm{H}_{2} \mathrm{O}(1.0 \mathrm{M}$ in THF, $2.0 \mathrm{~mL}, 2.0 \mathrm{mmol}, 2.0$ equiv $)$ and the resulting lightyellow solution was stirred under Ar for approximately $11 \mathrm{~min}$. A thermocouple was inserted to monitor the internal temperature. Then, $\mathrm{Pd}_{2}(\mathrm{dba})_{3} \cdot \mathrm{CHCl}_{3}(26 \mathrm{mg}, 0.025 \mathrm{mmol}, 2.5 \mathrm{~mol} \%)$ was 
added, and to this dark purple solution, ethyl 4-iodobenzoate (276 mg, $1.00 \mathrm{mmol}, 1.0$ equiv) was added dropwise in the course of $26 \mathrm{~min}$, during which the internal temperature was maintained between $26-29^{\circ} \mathrm{C}$. After the addition was completed, the internal temperature slowly decreased to $24{ }^{\circ} \mathrm{C}$ in approximately $1 \mathrm{~h}$. The reaction mixture was stirred at room temperature under Ar atmosphere for $2 \mathrm{~h}$. Then, the reaction mixture was passed through thin layer of silica gel (approximately $1 \mathrm{~cm})$ followed by a wash of EtOAc $(100 \mathrm{~mL})$. The dark-brown filtrate was added silica gel $(1 \mathrm{~g})$ and was concentrated under reduced pressure. The crude product adsorbed on silica gel was purified using flash chromatography (silica gel (50 g), hexane/EtOAc, 60/1 (1.5 L), 4/1 (500 mL), 20/1 (750 mL)) to afford $215.8 \mathrm{mg}(88 \%)$ of $\mathbf{2 0 a}$ as a yellow, viscous liquid. Product 20a was unable to be obtained analytically pure. Analytical sample obtained by further purification using flash chromagraphy (first column: silica gel (30 g), hexane/EtOAc, 40/1 (500 mL), 20/1 (500 mL), second column: silica gel (40 g), hexane/EtOAc, 40/1 (750 mL), 20/1 (500 $\mathrm{mL})$ ) and diffusion pump distillation.

\section{Data for 20a:}

b.p.: $\quad 140{ }^{\circ} \mathrm{C}(\mathrm{ABT})$ at $4.0 \times 10^{-5} \mathrm{mmHg}$

${ }^{1} \mathrm{H}$ NMR: $\quad\left(500 \mathrm{MHz}, \mathrm{CDCl}_{3}\right)$

$8.02(\mathrm{~d}, 2 \mathrm{H}, J=8.3,2 \times \mathrm{HC}(9)), 7.40(\mathrm{~d}, 2 \mathrm{H}, J=8.3,2 \times \mathrm{HC}(8)), 6.33(\mathrm{~d}, 1 \mathrm{H}, J$ $=1.7, \mathrm{HC}(6)), 4.60(\mathrm{dt}, 1 \mathrm{H}, J=13.7,1.7, \mathrm{HC}(2)), 4.40(\mathrm{dd}, 1 \mathrm{H}, J=13.5,1.8$, $\mathrm{HC}(2)), 4.38$ (q, $\left.2 \mathrm{H}, J=7.2, \mathrm{H}_{2} \mathrm{C}(12)\right), 3.99$ (dd, $\left.1 \mathrm{H}, J=8.5,5.9, \mathrm{HC}(5)\right), 3.76$ (dd, $1 \mathrm{H}, J=8.4,2.6, \mathrm{HC}(5))$, 3.20-3.27 (m, $1 \mathrm{H}, \mathrm{HC}(4)$ ), 1.40 (t, $3 \mathrm{H}, J=7.1$, $\left.\mathrm{H}_{3} \mathrm{C}(13)\right), 1.18\left(\mathrm{~d}, 3 \mathrm{H}, J=6.8, \mathrm{H}_{3} \mathrm{C}(14)\right)$.

${ }^{13} \mathrm{C} \mathrm{NMR:} \quad\left(126 \mathrm{MHz}, \mathrm{CDCl}_{3}\right)$

166.6 (C(11)), 149.2 (C(10)), 141.7 (C(7)), 129.9 (C(9)), 128.6 (C(3)), 128.1 (C(8)), 119.0 (C(6)), 76.6 (C(5)), 73.1 (C(2)), 61.1 (C(12)), 36.5 (C(4)), 17.6 (C(14)), 14.6 (C(13)).

$\underline{\text { IR: (neat) }}$

2974 (m), 1716 (s), 1606 (m), 1276 (s), 1179 (m), 1104 (m), 1020 (w), 879 (w), $769(\mathrm{w}), 700(\mathrm{w})$.

LRMS: (CI):

$247\left(30.5,[\mathrm{M}+\mathrm{H}]^{+}\right), 21.9$ (4.3), 201 (6.3), 185 (4.4), 157 (6.1), 145 (3.3), 131 (2.1), 119 (2.1), 102 (3.5), 86 (11.7), 86 (69.4), 83 (100.0). 
HRMS: $\left(\mathrm{CI},[\mathrm{M}+\mathrm{H}]^{+}\right)$:

calcd.: 247.13343

found: 247.13406

R $\underline{\underline{f}}: \quad 0.36$ (silica gel, hexane/EtOAc, 5/1, UV)

$\underline{t_{\mathrm{R}}}: \quad 1.541 \mathrm{~min}$ (Agilent Zorbax 300SB-C8, 100\% MeCN (2 mL/min))

Cross-Coupling Reaction of 8 with 4-Iodoanisole. Preparation of (Z)-3-(4Methoxybenzylidene)-4-methyltetrahydrofuran (20b).
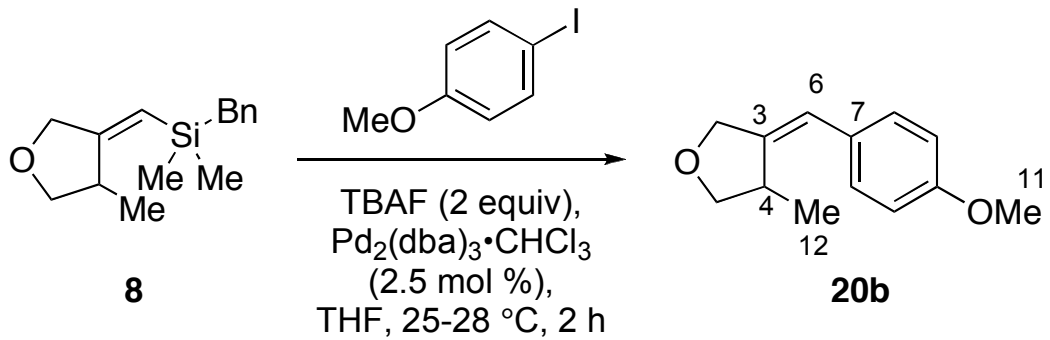

Alkylidenylsilane 8 (271 mg, $1.10 \mathrm{mmol}, 1.1$ equiv) in a 10-mL, two-necked, roundbottomed flask with a magnetic stir bar and fitted with a gas inlet adaptor, was dissolved in a solution of TBAF $\cdot 3 \mathrm{H}_{2} \mathrm{O}(1.0 \mathrm{M}$ in THF, $2.0 \mathrm{~mL}, 2.0 \mathrm{mmol}, 2.0$ equiv) and the resulting lightyellow solution was stirred under Ar for approximately $11 \mathrm{~min}$. A thermocouple was inserted to monitor the internal temperature. Then, $\mathrm{Pd}_{2}(\mathrm{dba})_{3} \cdot \mathrm{CHCl}_{3}(26 \mathrm{mg}, 0.025 \mathrm{mmol}, 2.5 \mathrm{~mol} \%$ ) was added, and to this dark purple solution, a solution of 4-iodoanisole (234 mg, $1.00 \mathrm{mmol}, 1.0$ equiv) in THF $(0.2 \mathrm{~mL})$ was added dropwise in the course of $30 \mathrm{~min}$, during which the internal temperature was maintained between $26-28^{\circ} \mathrm{C}$. After the addition was completed, the internal temperature slowly decreased to $25{ }^{\circ} \mathrm{C}$ in approximately $1 \mathrm{~h}$. The reaction mixture was stirred at room temperature under Ar atmosphere for $2 \mathrm{~h}$. Then, the reaction mixture was passed through thin layer of silica gel (approximately $1 \mathrm{~cm}$ ) followed by a wash of EtOAc $(100 \mathrm{~mL})$. The darkbrown filtrate was added silica gel $(1 \mathrm{~g})$ and was concentrated under reduced pressure. The crude product adsorbed on silica gel was purified using flash chromatography (silica gel $(50 \mathrm{~g})$, hexane/EtOAc, 80/1) to afford $286 \mathrm{mg}(89 \%)$ of $\mathbf{2 0 b}$ as a yellow, viscous liquid. Product $\mathbf{2 0 b}$ was unable to be obtained analytically pure. Analytical sample obtained by further purification using flash chromagraphy (first column: silica gel (40 g), hexane/DME, 80/1) and diffusion pump distillation. 
Data for 20b:

b.p.: $\quad 110^{\circ} \mathrm{C}(\mathrm{ABT})$ at $5.5 \times 10^{-5} \mathrm{mmHg}$

${ }^{1} \mathrm{H}$ NMR: $\quad\left(500 \mathrm{MHz}, \mathrm{CDCl}_{3}\right)$

$7.29(\mathrm{~d}, 2 \mathrm{H}, J=8.8,2 \times \mathrm{HC}(8)), 7.40(\mathrm{~d}, 2 \mathrm{H}, J=8.3,2 \times \mathrm{HC}(9)), 6.24(\mathrm{~d}, 1 \mathrm{H}, J$

$=1.7, \mathrm{HC}(6)), 4.57$ (dt, $1 \mathrm{H}, J=13.2,1.8, \mathrm{HC}(2)), 4.37$ (dd, $1 \mathrm{H}, J=13.0,1.9$, $\mathrm{HC}(2)), 3.97$ (dd, $1 \mathrm{H}, J=8.4,5.8, \mathrm{HC}(5)), 3.82$ (s, $3 \mathrm{H}, \mathrm{H}_{3} \mathrm{C}(11)$ ), 3.75 (dd, $1 \mathrm{H}$, $J=8.4,2.3, \mathrm{HC}(5)), 3.25-3.23$ (m, $1 \mathrm{H}, \mathrm{HC}(4)), 1.20$ (d, $\left.3 \mathrm{H}, J=7.1, \mathrm{H}_{3} \mathrm{C}(12)\right)$.

${ }^{13} \mathrm{C}$ NMR: $\left(126 \mathrm{MHz}, \mathrm{CDCl}_{3}\right)$

158.5 (C(10)), 144.1 (C(3)), 130.0 (C(7)), 129.4 (C(8)), 119.0 (C(6)), 114.1 (C(9)), 76.7 (C(5)), $73.0(\mathrm{C}(2)), 55.5$ (C(11)), 36.1 (C(4)), 17.7 (C(12)).

IR: (neat)

2966 (m), 2837 (m), 1608 (s), 1513 (s), 1463 (m), 1297 (m), 1250 (s), 1178 (s), $1089(\mathrm{~m}), 1034$ (s), 926 (s), 869 (m), $824(\mathrm{~m})$.

LRMS: (CI):

205 (100.0, $\left.[\mathrm{M}+\mathrm{H}]^{+}\right), 187$ (57.4), 175 (11.7), 162 (9.2), 147 (14.8), 137 (6.4), 121 (38.5).

HRMS: $\left(\mathrm{CI},[\mathrm{M}+\mathrm{H}]^{+}\right)$:

calcd.: 205.12286

found: 205.12278

$\underline{\mathrm{R}}_{\mathrm{f}}: \quad 0.43$ (silica gel, hexane/EtOAc, 5/1, UV)

$\underline{t_{\mathrm{R}}}: \quad 1.450 \mathrm{~min}$ (Agilent Zorbax 300SB-C8, 100\% MeCN (2 mL/min))

\section{Cross-Coupling Reaction of 8 with 2-Iodotoluene. Preparation of (Z)-3-(2-} Methylbenzylidene)-4-methyltetrahydrofuran (20c).

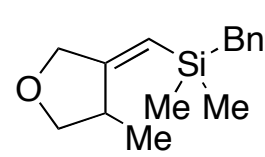

8

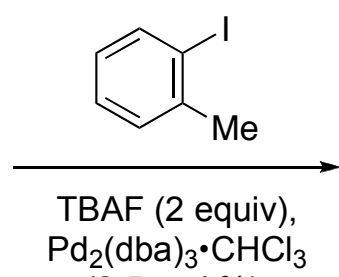

(2.5 mol \%),

$\mathrm{THF}, 19-25^{\circ} \mathrm{C}, 24 \mathrm{~h}$

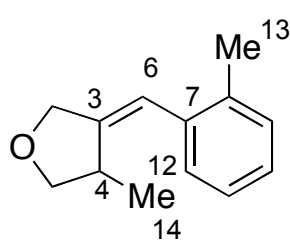

20c

Alkylidenylsilane 8 (271 mg, $1.10 \mathrm{mmol}, 1.1$ equiv) in a $10-\mathrm{mL}$, two-necked, roundbottomed flask with a magnetic stir bar and fitted with a gas inlet adaptor that was immersed in a 
room temperature water bath, was dissolved in a solution of TBAF• $3 \mathrm{H}_{2} \mathrm{O}(1.0 \mathrm{M}$ in THF, 2.0 $\mathrm{mL}, 2.0 \mathrm{mmol}, 2.0$ equiv) and the resulting light-yellow solution was stirred under Ar for approximately $3 \mathrm{~min}$. A thermocouple was inserted to monitor the internal temperature. Then, $\mathrm{Pd}_{2}(\mathrm{dba})_{3} \cdot \mathrm{CHCl}_{3}(26 \mathrm{mg}, 0.025 \mathrm{mmol}, 2.5 \mathrm{~mol} \%)$ was added, and to this dark purple solution, 2-iodotoluene (273 mg, $1.00 \mathrm{mmol}, 1.0$ equiv) was added dropwise in the course of $5 \mathrm{~min}$, during which the internal temperature was maintained between $19-21{ }^{\circ} \mathrm{C}$. After the addition was completed, the internal temperature slowly rose to $25^{\circ} \mathrm{C}$ in approximately $1 \mathrm{~h}$. The reaction mixture was stirred at room temperature under Ar atmosphere for $24 \mathrm{~h}$. Then, the reaction mixture was passed through thin layer of silica gel (approximately $1 \mathrm{~cm}$ ) followed by a wash of EtOAc $(100 \mathrm{~mL})$. The dark-brown filtrate was added silica gel $(1 \mathrm{~g})$ and was concentrated under reduced pressure. The crude product adsorbed on silica gel was purified using flash chromatography (first column: silica gel (45 g), hexane/EtOAc, 80/1 (500 mL), 60/1 (500 mL), second column: silica gel (45 g), hexane/EtOAc, 80/1 (500 mL), 60/1 (500 mL)) and diffusion pump distillation to afford $145 \mathrm{mg}(77 \%)$ of $20 \mathrm{c}$ as a colorless, viscous liquid.

\section{Data for 20c:}

b.p.: $\quad 82^{\circ} \mathrm{C}(\mathrm{ABT})$ at $8.0 \times 10^{-5} \mathrm{mmHg}$

${ }^{1} \mathrm{H}$ NMR: $\quad\left(500 \mathrm{MHz}, \mathrm{CDCl}_{3}\right)$

7.32-7.30 (m, 1 H, HC(12)), 7.20-7.15 (m, 3 H, HC(9), HC(10), HC(11)), 6.39 (d, $1 \mathrm{H}, J=1.9, \mathrm{HC}(6)), 4.56$ (dt, $1 \mathrm{H}, J=12.9,2.0, \mathrm{HC}(2)), 4.43$ (dd, $1 \mathrm{H}, J=13.0$, 1.7, HC(2)), $4.01(\mathrm{dd}, 1 \mathrm{H}, J=8.3,6.4, \mathrm{HC}(5)), 3.63$ (dd, $1 \mathrm{H}, J=8.5,3.8$, $\mathrm{HC}(5)), 3.12-3.09$ (m, $1 \mathrm{H}, \mathrm{HC}(4)), 2.28$ (s, $\left.3 \mathrm{H}, \mathrm{H}_{3} \mathrm{C}(13)\right), 0.96$ (d, $3 \mathrm{H}, J=6.8$, $\left.\mathrm{H}_{3} \mathrm{C}(14)\right)$.

${ }^{13} \mathrm{C} \mathrm{NMR:} \quad\left(126 \mathrm{MHz}, \mathrm{CDCl}_{3}\right)$

146.6 (C(3)), 136.9 (C(7)), 136.3 (C(aryl)), 130.0 (C(aryl)), 128.1 (C(12)), 127.1 (C(aryl)), 125.9 (C(aryl)), 118.5 (C(3)), 76.5 (C(5)), 72.6 (C(6)), 36.0 (C(4)), 20.2 (C(13)), 17.5 (C(14)).

IR: (neat)

2965 (s), 2851 (s), 1602 (w), 1480 (m), 1458 (m), 1379 (m), 1317 (m), 1150 (w), 1072 (s), 1042 (s), 926 (s), 745 (s).

LRMS: (ESI):

$187\left(100.0,[\mathrm{M}-1]^{+}\right)$. 
HRMS: (ESI, $\left.[\mathrm{M}-1]^{+}\right)$:

calcd.: 187.1123

found: 187.1123

Analysis: $\mathrm{C}_{13} \mathrm{H}_{16} \mathrm{O}$

(188.27)

calcd.: C, 82.94; $\quad$ H, 8.57.

found: C, 82.94; $\quad \mathrm{H}, 8.74$.

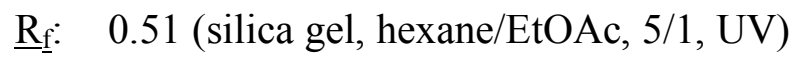

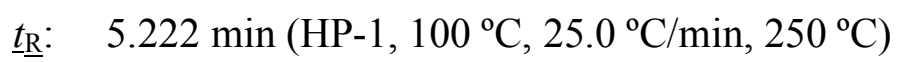

Cross-Coupling Reaction of 9 with Ethyl 4-Iodobenzoate. Preparation of Diethyl (Z)-3-(4Ethoxycarbonylphenyl)methylmethylidene-4-methylcyclopentane-1,1-dicarboxylate (21a).

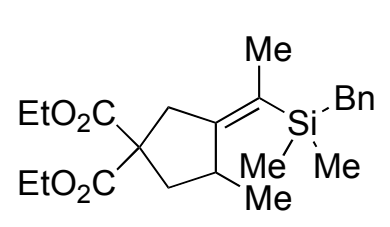

9

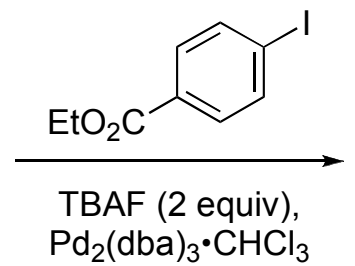

(2.5 mol \%),

THF, $25^{\circ} \mathrm{C}, 24 \mathrm{~h}$

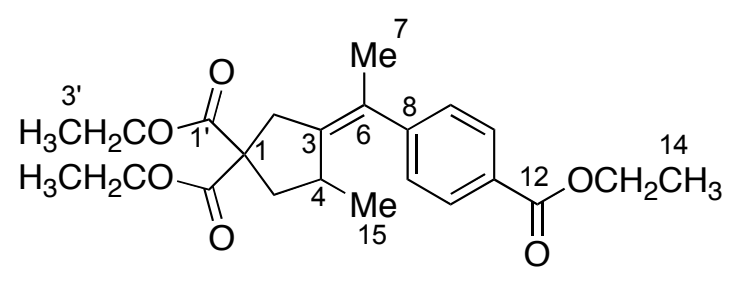

$21 a$

Alkylidenylsilane 9 (442 mg, $1.10 \mathrm{mmol}, 1.1$ equiv) in a $10-\mathrm{mL}$, round-bottomed flask with a magnetic stir bar and fitted with a gas inlet adaptor, was dissolved in a solution of TBAF $3 \mathrm{H}_{2} \mathrm{O}(1.0 \mathrm{M}$ in THF, $2.0 \mathrm{~mL}, 2.0 \mathrm{mmol}, 2.0$ equiv) and the resulting light-yellow solution was stirred at room temperature under Ar for approximately $3 \mathrm{~min}$. Then ethyl 4iodobenzoate (273 mg, $1.00 \mathrm{mmol}, 1.0$ equiv) and $\mathrm{Pd}_{2}(\mathrm{dba})_{3} \cdot \mathrm{CHCl}_{3}(26 \mathrm{mg}, 0.025 \mathrm{mmol}, 2.5$ mol \%) were added to the solution sequentially. The flask was purged with Ar, and the reaction mixture was stirred at $35{ }^{\circ} \mathrm{C}$ under Ar atmosphere for $24 \mathrm{~h}$. Then, the reaction mixture was passed through thin layer of silica gel (approximately $1 \mathrm{~cm}$ ) followed by a wash of EtOAc (100 $\mathrm{mL})$. The dark-brown filtrate was added silica gel $(1 \mathrm{~g})$ and was concentrated under reduced pressure. The crude product adsorbed on silica gel was purified using flash chromatography (first column: silica gel (45 g), hexane/EtOAc, 40/1 (250 mL), 30/1 (750 mL), 20/1 (500 mL), second column: silica gel $(50 \mathrm{~g})$, hexane/DME, 40/1 $(500 \mathrm{~mL}), 30 / 1(500 \mathrm{~mL})$, third column: silica gel $(60 \mathrm{~g})$, hexane/Et $2 \mathrm{O}, 40 / 1(750 \mathrm{~mL}), 30 / 1(500 \mathrm{~mL}), 20 / 1(500 \mathrm{~mL}), 10 / 1(250 \mathrm{~mL}), 5 / 1(250$ $\mathrm{mL}), 3 / 1(250 \mathrm{~mL})$ ), reverse phase flash chromatography (first column: reverse phase silica gel (70 g), $\mathrm{MeOH} / \mathrm{H}_{2} \mathrm{O}, 5 / 1$, second column: reverse phase silica gel $(71 \mathrm{~g}), \mathrm{MeOH} / \mathrm{H}_{2} \mathrm{O}, 3 / 1(325$ 
$\mathrm{mL}), 5 / 1(300 \mathrm{~mL}))$, and diffusion pump distillation to afford $289 \mathrm{mg}(72 \%)$ of 21 a as a white solid.

Data for 21a:

m.p.: $\quad 55-56^{\circ} \mathrm{C}$

b.p.: $\quad 150^{\circ} \mathrm{C}(\mathrm{ABT})$ at $6.0 \times 10^{-5} \mathrm{mmHg}$

1H NMR: $\quad\left(500 \mathrm{MHz}, \mathrm{CDCl}_{3}\right)$

$7.98(\mathrm{~d}, 2 \mathrm{H}, J=8.5,2 \times \mathrm{HC}(10)), 7.23(\mathrm{~d}, 2 \mathrm{H}, J=8.5,2 \times \mathrm{HC}(9)), 4.38(\mathrm{q}, 2 \mathrm{H}$, $\left.J=7.2, \mathrm{H}_{2} \mathrm{C}(13)\right), 4.24$ (q, $\left.2 \mathrm{H}, J=7.1, \mathrm{H}_{2} \mathrm{C}\left(2^{\prime}\right)\right), 4.22$ (q, $\left.2 \mathrm{H}, J=7.4, \mathrm{H}_{2} \mathrm{C}\left(2^{\prime}\right)\right)$, 3.06 (s, $2 \mathrm{H}, \mathrm{HC}(2)), 2.91-2.87$ (m, $1 \mathrm{H}, \mathrm{HC}(4)), 2.58$ (dd, $1 \mathrm{H}, J=13.3,8.0$, $\mathrm{HC}(5)), 1.97$ (s, $\left.3 \mathrm{H}, \mathrm{H}_{3} \mathrm{C}(7)\right), 1.85$ (dd, $\left.1 \mathrm{H}, J=13.2,7.1, \mathrm{HC}(5)\right), 1.40$ (t, $3 \mathrm{H}, J$ $\left.=7.1, \mathrm{H}_{3} \mathrm{C}(14)\right), 1.29$ (t, $\left.3 \mathrm{H}, J=6.7, \mathrm{H}_{3} \mathrm{C}\left(3^{\prime}\right)\right), 1.28$ (t, $3 \mathrm{H}, J=6.7, \mathrm{H}_{3} \mathrm{C}\left(3^{\prime}\right)$ ), $0.61\left(\mathrm{~d}, 3 \mathrm{H}, J=6.8, \mathrm{H}_{3} \mathrm{C}(15)\right)$.

${ }^{13} \mathrm{C}$ NMR: $\quad\left(126 \mathrm{MHz}, \mathrm{CDCl}_{3}\right)$

$172.3\left(\mathrm{C}\left(1^{\prime}\right)\right), 172.3\left(\mathrm{C}\left(1^{\prime}\right)\right), 166.8(\mathrm{C}(12)), 149.2(\mathrm{C}(3)), 141.2(\mathrm{C}(8)), 129.7$ (C(10)), 128.8 (C(11)), $128.6(\mathrm{C}(11)), 128.1(\mathrm{C}(9)), 61.7$ (C(2')), $61.7\left(\mathrm{C}\left(2^{\prime}\right)\right)$, $61.1(\mathrm{C}(13)), 59.1(\mathrm{C}(1)), 42.4(\mathrm{C}(5)), 39.3(\mathrm{C}(2)), 35.7$ (C(4)), 22.3 (C(7)), 20.2 $(\mathrm{C}(15)), 14.6(\mathrm{C}(14)), 14.3\left(\mathrm{C}\left(3^{\prime}\right)\right), 14.3\left(\mathrm{C}\left(3^{\prime}\right)\right)$.

IR: (neat)

2981 (m), 1731 (s), 1607 (m), 1447 (s), 1367 (m), 1273 (s), 1179 (s), 1102 (s), $1076(\mathrm{~s}), 1020(\mathrm{~m}), 861(\mathrm{~m}), 777(\mathrm{~m}), 712(\mathrm{~m})$.

LRMS: (EI):

402 (27.6, $\left.[\mathrm{M}]^{+}\right), 357$ (16.9), 328 (100.0), 283 (14.2), 255 (49.1), 177 (22.2).

HRMS: (EI, $\left.[\mathrm{M}]^{+}\right)$:

calcd.: 402.2042

found: 402.2039

Analysis: $\mathrm{C}_{20} \mathrm{H}_{26} \mathrm{O}_{5} \quad(402.48)$

calcd.: C, 68.64; H, 7.51.

found: C, 68.63; $\quad \mathrm{H}, 7.35$.

$\underline{\mathrm{R}}_{\mathrm{f}}: \quad 0.44$ (silica gel, hexane/EtOAc, 5/1, UV)

$\underline{t_{\mathrm{R}}}: \quad 2.758 \mathrm{~min}$ (Agilent Zorbax 300SB-C8, 100\% MeCN (1 mL/min)) 


\section{Cross-Coupling Reaction of 9 with 4-Iodoanisole. Preparation of Diethyl (Z)-3-(4-} Methoxyphenyl)methylmethylidene-4-methylcyclopentane-1,1-dicarboxylate (21b).

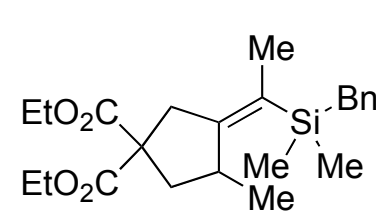

9

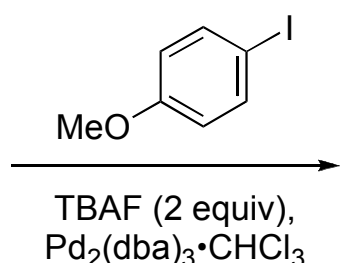

$(2.5 \mathrm{~mol} \%)$

THF, $35^{\circ} \mathrm{C}, 24 \mathrm{~h}$

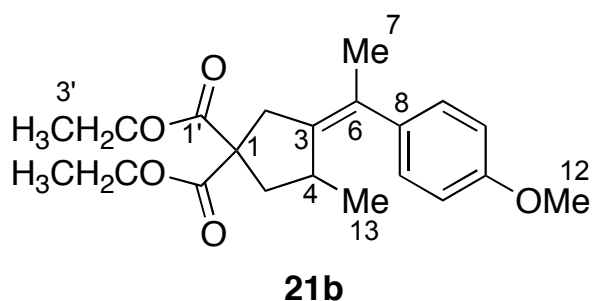

21b

Alkylidenylsilane 9 (443 mg, $1.10 \mathrm{mmol}, 1.1$ equiv) in a 10-mL, round-bottomed flask with a magnetic stir bar and fitted with a gas inlet adaptor, was dissolved in a solution of $\mathrm{TBAF} \cdot 3 \mathrm{H}_{2} \mathrm{O}(1.0 \mathrm{M}$ in THF, $2.0 \mathrm{~mL}, 2.0 \mathrm{mmol}, 2.0$ equiv) and the resulting light-yellow solution was stirred at room temperature under Ar for approximately $3 \mathrm{~min}$. Then 4-iodoanisole (234 mg, $1.00 \mathrm{mmol}, 1.0$ equiv) and $\mathrm{Pd}_{2}(\mathrm{dba})_{3} \cdot \mathrm{CHCl}_{3}(26 \mathrm{mg}, 0.025 \mathrm{mmol}, 2.5 \mathrm{~mol} \%$ ) were added to the solution sequentially. The flask was purged with Ar, and the reaction mixture was stirred at $35^{\circ} \mathrm{C}$ under Ar for $24 \mathrm{~h}$. Then, the reaction mixture was passed through thin layer of silica gel (approximately $1 \mathrm{~cm}$ ) followed by a wash of EtOAc $(100 \mathrm{~mL})$. The dark-brown filtrate was added silica gel (1 g) and was concentrated under reduced pressure. The crude product adsorbed on silica gel was purified using flash chromatography (first column: silica gel (45 g), hexane/EtOAc, 60/1 (250 mL), 20/1 (750 mL), 10/1 (500 mL), second column silica gel (45 g), hexane/EtOAc, 60/1 (250 mL), 40/1 (500 mL), 30/1 (500 mL), 20/1 (250 mL)) and diffusion pump distillation to afford $278 \mathrm{mg}(77 \%)$ of 21 a as a yellow, viscous liquid.

\section{Data for 21a:}

b.p.: $\quad 159^{\circ} \mathrm{C}(\mathrm{ABT})$ at $6.0 \times 10^{-5} \mathrm{mmHg}$

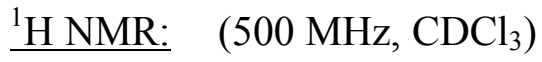

7.07 (d, $2 \mathrm{H}, J=8.1,2 \times \mathrm{HC}(9)), 6.84$ (d, $2 \mathrm{H}, J=8.1,2 \times \mathrm{HC}(10)), 4.23$ (q, $2 \mathrm{H}$, $\left.J=7.2, \mathrm{H}_{2} \mathrm{C}\left(2^{\prime}\right)\right), 4.21$ (q, $\left.2 \mathrm{H}, J=7.2, \mathrm{H}_{2} \mathrm{C}\left(2^{\prime}\right)\right)$ ), 3.80 (s, $\left.3 \mathrm{H}, \mathrm{H}_{3} \mathrm{C}(12)\right), 3.04$ (s, $2 \mathrm{H}, \mathrm{HC}(2)), 2.91-2.87$ (m, $1 \mathrm{H}, \mathrm{HC}(4)), 2.56$ (dd, $1 \mathrm{H}, J=13.1,8.0, \mathrm{HC}(5)), 1.94$ (s, $\left.3 \mathrm{H}, \mathrm{H}_{3} \mathrm{C}(7)\right), 1.82$ (dd, $1 \mathrm{H}, J=13.1,7.2$, HC(5)), 1.28 (td, $3 \mathrm{H}, J=6.7,1.0$, $\left.\mathrm{H}_{3} \mathrm{C}\left(3^{\prime}\right)\right), 1.27$ (td, $\left.3 \mathrm{H}, J=6.7,0.8, \mathrm{H}_{3} \mathrm{C}\left(3^{\prime}\right)\right)$, 0.64 (d, 3H, $\left.J=6.8, \mathrm{H}_{3} \mathrm{C}(13)\right)$.

${ }^{13} \mathrm{C} \mathrm{NMR:} \quad\left(126 \mathrm{MHz}, \mathrm{CDCl}_{3}\right)$

172.3 (C(1')), 172.2 (C(1')), 158.1 (C(3)), 139.7 (C(11)), 136.7 (C(8)), 129.0 (C(9)), 113.7 (C(10)), $61.6\left(\mathrm{C}\left(2^{\prime}\right)\right), 61.6\left(\mathrm{C}\left(2^{\prime}\right)\right), 59.2$ (C(1)), 55.4 (C(12)), 42.5 
(C(5)), $39.2(\mathrm{C}(2)), 35.7(\mathrm{C}(4)), 22.7$ (C(7)), 20.2 (C(13)), 14.3 (C(3’)), 14.3 $\left(\mathrm{C}\left(3^{\prime}\right)\right)$.

$\underline{\text { IR: (neat) }}$

2980 (s), 1731 (s), 1608 (m), 1511 (s), 1464 (m), 1296 (s), 1243 (s), 1181 (s), 1105 (m), 1044 (m), $833(\mathrm{~m})$.

LRMS: (EI):

360 (40.3, $\left.[\mathrm{M}]^{+}\right), 286(100.0), 271$ (15.8), 213 (40.7), 197 (11.1), 173 (15.4), 135 (36.4), 77 (9.8).

HRMS: (EI, [M] $\left.]^{+}\right)$:

calcd.: 360.1937

found: 360.1944

Analysis: $\mathrm{C}_{20} \mathrm{H}_{26} \mathrm{O}_{5} \quad(360.44)$

calcd.: C, 69.98; H, 7.83 .

found: C, 69.87; $\quad \mathrm{H}, 7.92$.

$\underline{\mathrm{R}}_{\mathrm{f}}: \quad 0.61$ (silica gel, hexane/EtOAc, 5/1, UV)

$\underline{t_{\mathrm{R}}}: \quad 2.73 \mathrm{~min}$ (Agilent Zorbax 300SB-C8, 100\% MeCN (1 mL/min))

Cross-Coupling Reaction of 9 with 2-Iodotoluene. Preparation of Diethyl (Z)-3-(2Methylphenyl)methylmethylidene-4-methylcyclopentane-1,1-dicarboxylate (21c).

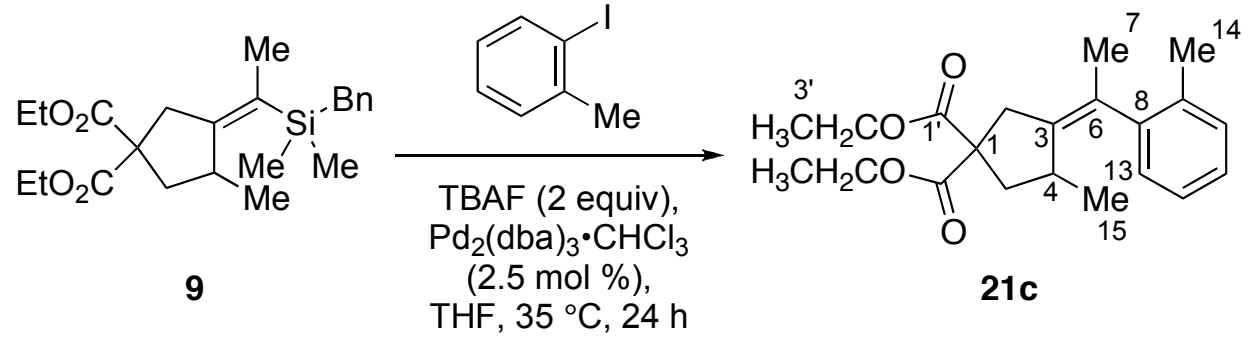

Alkylidenylsilane 9 (443 mg, $1.10 \mathrm{mmol}, 1.1$ equiv) in a 5-mL, round-bottomed flask with a magnetic stir bar and fitted with a gas inlet adaptor, was dissolved in a solution of $\mathrm{TBAF} \cdot 3 \mathrm{H}_{2} \mathrm{O}(1.0 \mathrm{M}$ in THF, $2.0 \mathrm{~mL}, 2.0 \mathrm{mmol}, 2.0$ equiv) and the resulting light-yellow solution was stirred at room temperature under Ar for approximately $3 \mathrm{~min}$. Then 2-iodotoluene (224 mg, $1.00 \mathrm{mmol}, 1.0$ equiv) and $\mathrm{Pd}_{2}(\mathrm{dba})_{3} \cdot \mathrm{CHCl}_{3}(26 \mathrm{mg}, 0.025 \mathrm{mmol}, 2.5 \mathrm{~mol} \%$ ) were added to the solution sequentially. The flask was purged with Ar, and the reaction mixture was stirred at room temperature under Ar atmosphere for $24 \mathrm{~h}$. Then, the reaction mixture was passed 
through thin layer of silica gel (approximately $1 \mathrm{~cm}$ ) followed by a wash of EtOAc $(100 \mathrm{~mL})$. The dark-brown filtrate was added silica gel $(1 \mathrm{~g})$ and was concentrated under reduced pressure. The crude product adsorbed on silica gel was purified using flash chromatography (silica gel (50 g), hexane/EtOAc, 60/1 (500 mL), 40/1 (500 mL), 20/1 (500 mL)), reverse phase flash chromatography (reverse phase silica gel $(90 \mathrm{~g}), \mathrm{MeOH} / \mathrm{H}_{2} \mathrm{O}, 3 / 1$ (1 L), 5/1 (500 mL)), and diffusion pump distillation to afford $221 \mathrm{mg}(64 \%)$ of 21c as a colorless, viscous liquid.

Data for 21c:

b.p.: $\quad 120^{\circ} \mathrm{C}(\mathrm{ABT})$ at $7.5 \times 10^{-5} \mathrm{mmHg}$

1H NMR: $\quad\left(500 \mathrm{MHz}, \mathrm{CDCl}_{3}\right)$

7.17-7.10 (m, 3 H, HC(10), HC(11), HC(12)), 7.03-7.00 (m, 0.5 H, HC(13)), 6.95 (d, 0.5 H, $J=7.6, \mathrm{HC}(13)), 4.23-4.18$ (m, $\left.4 \mathrm{H}, 2 \times \mathrm{H}_{2} \mathrm{C}\left(2^{\prime}\right)\right), 3.14$ (d, $0.5 \mathrm{H}, J=$ 16.6, $\mathrm{HC}(2)), 3.04\left(\mathrm{dm}, 1.5 \mathrm{H}, J=18.1, \mathrm{H}_{2} \mathrm{C}(2)\right), 2.72-2.68(\mathrm{~m}, 0.5 \mathrm{H}, \mathrm{HC}(4)$ (A)), 2.57 (ddd, $1 \mathrm{H}, J=12.9,8.0,1.1, \mathrm{HC}(5)$ ), 2.37-2.33 (m, $0.5 \mathrm{H}, \mathrm{HC}(4)$ (B)), 2.22 (s, $\left.1.5 \mathrm{H}, \mathrm{H}_{3} \mathrm{C}(14)\right), 2.14$ (s, $\left.1.5 \mathrm{H}, \mathrm{H}_{3} \mathrm{C}(14)\right), 1.88$ (s, $\left.1.5 \mathrm{H}, \mathrm{H}_{3} \mathrm{C}(7)\right), 1.87$ (d, $\left.1.5 \mathrm{H}, J=1.2, \mathrm{H}_{3} \mathrm{C}(7)\right), 1.82$ (dd, $\left.0.5 \mathrm{H}, J=13.0,6.6, \mathrm{HC}(5)\right), 1.80$ (dd, $0.5 \mathrm{H}$, $J=12.9,7.6, \mathrm{HC}(5)), 1.29$ (t, $1.5 \mathrm{H}, J=7.3, \mathrm{H}_{3} \mathrm{C}\left(3^{\prime}\right)$ ), 1.28 (t, $1.5 \mathrm{H}, J=7.3$, $\left.\mathrm{H}_{3} \mathrm{C}\left(3^{\prime}\right)\right), 0.67\left(\mathrm{~d}, 1.5 \mathrm{H}, J=7.1, \mathrm{H}_{3} \mathrm{C}(15)(\mathrm{B})\right), 0.54$ (d, $1.5 \mathrm{H} . J=6.8$, $\left.\mathrm{H}_{3} \mathrm{C}(15)(\mathrm{A})\right)$.

${ }^{13} \mathrm{C}$ NMR: $\quad\left(126 \mathrm{MHz}, \mathrm{CDCl}_{3}\right)$

$172.5\left(\mathrm{C}\left(1^{\prime}\right)\right), 172.4\left(\mathrm{C}\left(1^{\prime}\right)\right), 172.2\left(\mathrm{C}\left(1^{\prime}\right)\right), 172.2\left(\mathrm{C}\left(1^{\prime}\right)\right), 143.8(\mathrm{C}(3)), 143.2$ (C(3)), $159.7(\mathrm{C}(8)), 139.6(\mathrm{C}(8)), 135.7(\mathrm{C}(9)), 134.5(\mathrm{C}(9)), 130.2$ (C(aryl)), 130.1 (C(aryl)), 130.0 (C(13)), 129.2 (C(aryl)), 129.0 (C(13)), 126.8 (C(aryl)), 126.6 (C(aryl)), 126.1 (C(aryl)), 125.5 (C(aryl)), 61.7 (C(2’)), $61.6\left(\mathrm{C}\left(2^{\prime}\right)\right), 59.3$ (C(1)), 42.5 (C(5)), 42.2 (C(5)), 38.8 (C(2)), $38.4(\mathrm{C}(2)), 36.2$ (C(4)), 35.7 (C(4)), 22.2 (C(7)), $21.5(\mathrm{C}(7)), 21.0$ (C(15)), 19.7 (C(14)), 19.0 (C(14)), 18.9 (C(15)), $14.3\left(\mathrm{C}\left(3^{\prime}\right)\right), 14.3\left(\mathrm{C}\left(3^{\prime}\right)\right)$.

IR: (neat)

$2980(\mathrm{~m}), 1732$ (s), $1448(\mathrm{~m}), 1367$ (m), 1277 (s), 1244 (s), $1282(\mathrm{~s}), 1100(\mathrm{~m})$, $1075(\mathrm{~m}), 1048(\mathrm{~m}), 863$ (w), 764 (m), 732 (m). 
LRMS: (EI):

344 (43.9, $\left.[\mathrm{M}]^{+}\right), 299$ (7.9), 270 (100.0), 241 (10.7), 197 (54.3), 181 (13.5), 119 (32.4).

HRMS: (EI, $\left.[\mathrm{M}]^{+}\right)$:

calcd.: 344.1988

found: 344.1986

Analysis: $\mathrm{C}_{21} \mathrm{H}_{28} \mathrm{O}_{4}$

(344.44)

calcd.: C, 73.23; $\quad$ H, 8.19.

found: C, 72.96; $\quad \mathrm{H}, 8.05$.

․․․: $\quad 0.64$ (silica gel, hexane/EtOAc, 5/1, UV)

$\underline{t_{\mathrm{R}}}: \quad 2.703 \mathrm{~min}$ (Agilent Zorbax 300SB-C8, 100\% MeCN (1 mL/min))

Cross-Coupling Reaction of 10 with Ethyl 4-Iodobenzoate. Preparation of Diethyl (Z)-3-(4Ethoxycarbonylbenzylidene)-4-methoxycarbonylcyclopentane-1,1-dicarboxylate (22a).

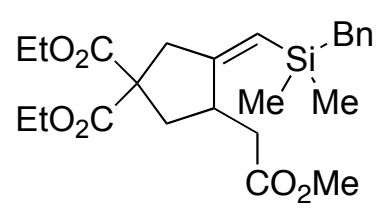

10

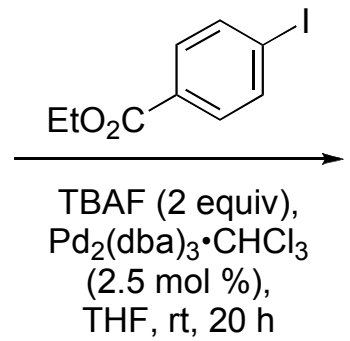

Alkylidenylsilane 10 (491 mg, $1.10 \mathrm{mmol}, 1.1$ equiv) in a $10-\mathrm{mL}$, round-bottomed flask with a magnetic stir bar and fitted with a gas inlet adaptor, was dissolved in a solution of TBAF• $3 \mathrm{H}_{2} \mathrm{O}(1.0 \mathrm{M}$ in THF, $2.0 \mathrm{~mL}, 2.0 \mathrm{mmol}, 2.0$ equiv $)$ and the resulting light-yellow solution was stirred at room temperature under Ar for approximately $3 \mathrm{~min}$. Then ethyl 4iodobenzoate (491 mg, $1.00 \mathrm{mmol}, 1.0$ equiv) and $\mathrm{Pd}_{2}\left(\mathrm{dba}_{3}\right)_{3} \cdot \mathrm{CHCl}_{3}(26 \mathrm{mg}, 0.025 \mathrm{mmol}, 2.5$ mol \%) were added to the solution sequentially. The flask was purged with Ar, and the reaction mixture was stirred at room temperature under Ar atmosphere for $20 \mathrm{~h}$. Then, the reaction mixture was passed through thin layer of silica gel (approximately $1 \mathrm{~cm}$ ) followed by a wash of EtOAc $(100 \mathrm{~mL})$. The dark-brown filtrate was added silica gel $(1 \mathrm{~g})$ and was concentrated under reduced pressure. The crude product adsorbed on silica gel was purified using flash chromatography (silica gel $(45 \mathrm{~g})$, hexane/EtOAc, 30/1 (250 mL), 20/1 (500 mL), 10/1 (500 $\mathrm{mL}), 5 / 1(500 \mathrm{~mL}))$, reverse phase flash chromatography (reverse phase silica gel $(74 \mathrm{~g})$, 
$\left.\mathrm{MeOH} / \mathrm{H}_{2} \mathrm{O}, 5 / 1\right)$, and diffusion pump distillation to afford $333 \mathrm{mg}(74 \%)$ of 22a as a colorless, viscous liquid.

Data for 22a:

b.p.: $\quad 188^{\circ} \mathrm{C}(\mathrm{ABT})$ at $6.0 \times 10^{-5} \mathrm{mmHg}$

1N NMR: $\quad\left(500 \mathrm{MHz}, \mathrm{CDCl}_{3}\right)$

$7.20(\mathrm{~d}, 2 \mathrm{H}, J=8.3,2 \times \mathrm{HC}(9)), 6.86(\mathrm{~d}, 2 \mathrm{H}, J=8.3,2 \times \mathrm{HC}(8)), 6.45(\mathrm{~s}, 1 \mathrm{H}$, $\mathrm{HC}(6)), 4.37$ (q, $\left.2 \mathrm{H}, J=7.1, \mathrm{H}_{2} \mathrm{C}(12)\right)$, 4.24-4.18 (m, $\left.4 \mathrm{H}, 2 \times \mathrm{H}_{2} \mathrm{C}\left(2^{\prime}\right)\right)$, 3.72-

3.64 (m, $1 \mathrm{H}, \mathrm{HC}(4)), 3.64$ (s, 3H, $\left.\mathrm{H}_{3} \mathrm{C}(16)\right), 3.25$ (dt, $1 \mathrm{H}, J=16.6,2.3$, HC(2)), $3.05(\mathrm{~d}, 1 \mathrm{H}, J=16.6, \mathrm{HC}(2)), 4.22(\mathrm{ddd}, 1 \mathrm{H}, J=13.7,8.4,1.2, \mathrm{HC}(5)), 2.55$ (dd, $1 \mathrm{H}, J=16.1,3.4, \mathrm{HC}(14)), 2.17$ (dd, $1 \mathrm{H}, J=16.1,11.2, \mathrm{HC}(14)), 2.11$ (dd, $1 \mathrm{H}$, $J=13.7,6.1, \mathrm{HC}(5)), 1.39\left(\mathrm{t}, 3 \mathrm{H}, J=8.1, \mathrm{H}_{3} \mathrm{C}(13)\right), 1.27$ (t, $3 \mathrm{H}, J=7.2$, $\left.\mathrm{H}_{3} \mathrm{C}\left(3^{\prime}\right)\right), 1.25$ (t, $\left.3 \mathrm{H}, J=7.2, \mathrm{H}_{3} \mathrm{C}\left(3^{\prime}\right)\right)$.

${ }^{13} \mathrm{C}$ NMR: $\quad\left(126 \mathrm{MHz}, \mathrm{CDCl}_{3}\right)$

172.6 (C(1')), 171.7 (C(1')), 171.5 (C(11)), 166.6 (C(15)), 146.7 (C(3)), 141.6 (C(7)), 130.0 (C(9)), 128.7 (C(10)), 128.2 (C(8)), 123.0 (C(6)), 61.9 (C(2')), 61.9 (C(2')), 61.1 (C(12)), 58.5 (C(1)), 51.9 (C(16)), 43.6 (C(2)), 40.3 (C(5)), 37.5 (C(14)), 36.7 (C(4)), 14.5 (C(13)), 14.2 (C(3’)), 14.2 (C(3’)).

IR: (neat)

2983 (s), 1731 (s), 1607 (s), 1446 (m), 1367 (s), 1276 (s), 1179 (s), 1105 (s), 1074 (s), $1021(\mathrm{~s}), 864(\mathrm{~m}), 769(\mathrm{~m}), 705(\mathrm{~m})$.

LRMS: (CI):

447 (56.1, $\left.[\mathrm{M}+\mathrm{H}]^{+}\right), 415$ (23.6), 401 (100.0), 373 (50.0), 355 (13.0), 341 (12.4), 327 (62.9), 299 (7.2).

HRMS: $\left(\mathrm{CI},[\mathrm{M}+\mathrm{H}]^{+}\right)$:

calcd.: 447.2019

found: 447.2025

Analysis: $\mathrm{C}_{20} \mathrm{H}_{26} \mathrm{O}_{5} \quad(446.49)$

calcd.: C, 64.56; H, 6.77.

found: C, 64.69; $\mathrm{H}, 6.67$.

$\underline{\mathrm{R}_{\mathrm{f}}}$ : $\quad 0.10$ (silica gel, hexane/EtOAc, 5/1, UV)

$\underline{t_{\mathrm{R}}}: \quad 2.608 \mathrm{~min}$ (Agilent Zorbax 300SB-C8, 100\% MeCN (1 mL/min)) 


\section{Cross-Coupling Reaction of 10 with 4-Iodoanisole. Preparation of Diethyl (Z)-3-(4-} Methoxybenzylidene)-4-methoxycarbonylcyclopentane-1,1-dicarboxylate (22b).
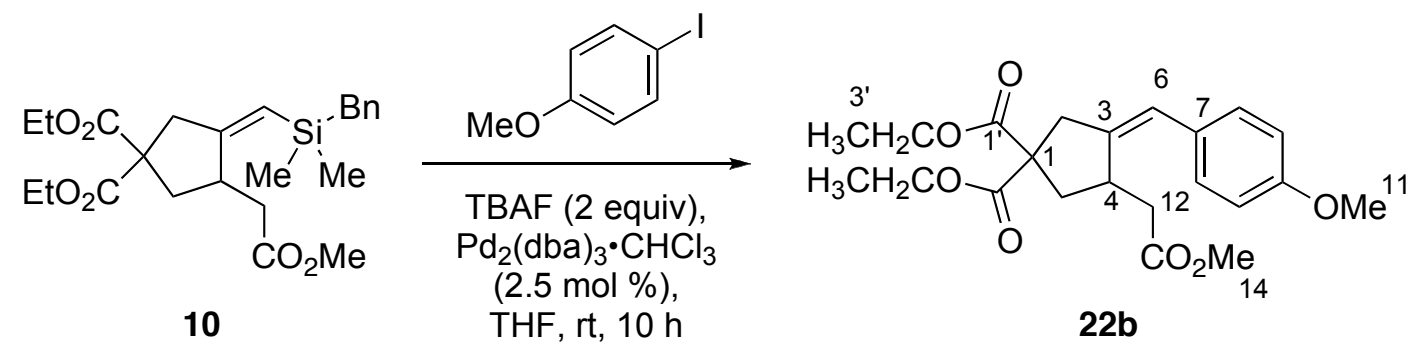

Alkylidenylsilane 10 (476 mg, $1.10 \mathrm{mmol}, 1.1$ equiv) in a 10-mL, round-bottomed flask with a magnetic stir bar and fitted with a gas inlet adaptor, was dissolved in a solution of $\mathrm{TBAF} \cdot 3 \mathrm{H}_{2} \mathrm{O}(1.0 \mathrm{M}$ in THF, $2.0 \mathrm{~mL}, 2.0 \mathrm{mmol}, 2.0$ equiv) and the resulting light-yellow solution was stirred at room temperature under Ar for approximately $3 \mathrm{~min}$. Then 4-iodoanisole (234 mg, $1.00 \mathrm{mmol}, 1.0$ equiv) and $\mathrm{Pd}_{2}(\mathrm{dba})_{3} \cdot \mathrm{CHCl}_{3}(26 \mathrm{mg}, 0.025 \mathrm{mmol}, 2.5 \mathrm{~mol} \%$ ) were added to the solution sequentially. The flask was purged with Ar, and the reaction mixture was stirred at room temperature under Ar atmosphere for $10 \mathrm{~h}$. Then, the reaction mixture was passed through thin layer of silica gel (approximately $1 \mathrm{~cm})$ followed by a wash of EtOAc $(100 \mathrm{~mL})$. The dark-brown filtrate was added silica gel $(1 \mathrm{~g})$ and was concentrated under reduced pressure. The crude product adsorbed on silica gel was purified using flash chromatography (first column: silica gel (45 g), hexane/EtOAc, 30/1 (250 mL), 20/1 (250 mL), 10/1 (250 mL), 5/1 (500 mL), second column: silica gel (50 g), hexane/DME, 40/1 (500 mL), 30/1 (250 mL), 20/1 (1 L), 10/1 (500 mL), third column: silica gel (15 g), hexane/DME, 20/1) and diffusion pump distillation to afford $311 \mathrm{mg}(77 \%)$ of $\mathbf{2 2 b}$ as a yellow, viscous liquid.

Data for 22b:

b.p.: $\quad 185^{\circ} \mathrm{C}(\mathrm{ABT})$ at $6.5 \times 10^{-5} \mathrm{mmHg}$

${ }^{1} \mathrm{H}$ NMR: $\quad\left(500 \mathrm{MHz}, \mathrm{CDCl}_{3}\right)$

$7.20(\mathrm{~d}, 2 \mathrm{H}, J=8.8,2 \times \mathrm{HC}(8)), 6.86(\mathrm{~d}, 2 \mathrm{H}, J=8.8,2 \times \mathrm{HC}(9)), 6.26(\mathrm{~s}, 1 \mathrm{H}$, $\mathrm{HC}(6))$, 4.24-4.17 (m, 4 H, $\left.2 \times \mathrm{H}_{2} \mathrm{C}\left(2^{\prime}\right)\right)$ ), 3.81 (s, 3 H, $\mathrm{H}_{3} \mathrm{C}(11)$ ), 3.70-3.60 (m, 1 H, $\mathrm{HC}(4)), 3.65$ (s, 3H, H3 C(14)), 3.21 (dt, $1 \mathrm{H}, J=16.1,2.3, \mathrm{HC}(2)), 3.00$ (d, 1 $\mathrm{H}, J=16.1, \mathrm{HC}(2)), 2.80(\mathrm{ddd}, 1 \mathrm{H}, J=13.6,8.3,1.5, \mathrm{HC}(5)), 2.64$ (dd, $1 \mathrm{H}, J=$ 16.1, 3.4, HC(12)), 2.17 (dd, $1 \mathrm{H}, J=16.1,11.1$, HC(12)), 2.09 (dd, $1 \mathrm{H}, J=13.7$, 5.9, $\mathrm{HC}(5)), 1.27$ (t, $\left.3 \mathrm{H}, J=7.1, \mathrm{H}_{3} \mathrm{C}\left(3^{\prime}\right)\right), 1.25$ (t, $3 \mathrm{H}, J=7.1, \mathrm{H}_{3} \mathrm{C}\left(3^{\prime}\right)$ ). 
${ }^{13} \mathrm{C} \mathrm{NMR:} \quad\left(126 \mathrm{MHz}, \mathrm{CDCl}_{3}\right)$

173.1 (C(13)), 171.9 (C(1')), 171.6 (C(1')), 158.4 (C(3)), 141.9 (C(7)), 129.7

(C(10)), 129.5 (C(8)), 123.2 (C(6)), 114.1 (C(9)), 61.8 (C(2')), 61.7 (C(2’)), 58.6

(C(1)), 55.5 (C(11)), 51.8 (C(14)), 43.4 (C(2)), 40.4 (C(5)), $36.5(\mathrm{C}(4)), 14.3$

$\left(\mathrm{C}\left(3^{\prime}\right)\right), 14.2\left(\mathrm{C}\left(3^{\prime}\right)\right)$.

IR: (neat)

2982 (s), 2939 (m), 1731 (s), 1608 (s), 1512 (s), 1443 (m), 1367 (m), 1252 (s),

1178 (s), 1074 (s), 1032 (s), 863 (m), 832 (m).

LRMS: (EI):

$404\left(67.9,[\mathrm{M}]^{+}\right), 330$ (100.0), 257 (59.5), 205 (26.8), 197 (32.4), 183 (19.5), 121

(79.0).

HRMS: (EI, [M] $\left.]^{+}\right)$:

calcd.: 404.1835

found: 404.1839

Analysis: $\mathrm{C}_{20} \mathrm{H}_{26} \mathrm{O}_{5} \quad(404.45)$

calcd.: C, 65.77; H, 6.98 .

found: C, 65.36; $\mathrm{H}, 6.91$.

$\underline{\mathrm{R}}_{\mathrm{f}}: \quad 0.21$ (silica gel, hexane/EtOAc, 5/1, UV)

$\underline{t_{\mathrm{R}}}: \quad 2.675 \mathrm{~min}$ (Agilent Zorbax 300SB-C8, 100\% MeCN (1 mL/min))

Cross-Coupling Reaction of 10 with 2-Iodobenzene. Preparation of Diethyl (Z)-3-(2Methylbenzylidene)-4-methoxycarbonylcyclopentane-1,1-dicarboxylate (22c).<smiles>CCOC(=O)C1(C(=O)OCC)C/C(=C/[Si](C)(Cc2ccccc2)C(C)OC)CC1COC</smiles>

10

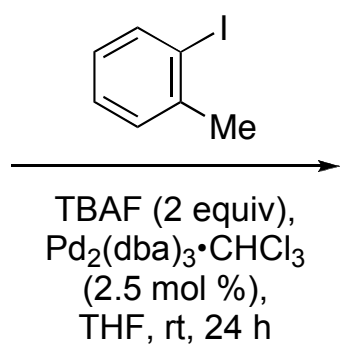

THF, rt, $24 \mathrm{~h}$

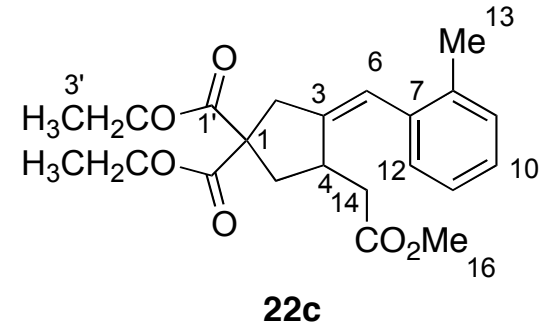

22c

Alkylidenylsilane 10 (476 mg, $1.10 \mathrm{mmol}, 1.1$ equiv) in a 10-mL, round-bottomed flask with a magnetic stir bar and fitted with a gas inlet adaptor, was dissolved in a solution of $\mathrm{TBAF} \cdot 3 \mathrm{H}_{2} \mathrm{O}(1.0 \mathrm{M}$ in THF, $2.0 \mathrm{~mL}, 2.0 \mathrm{mmol}, 2.0$ equiv) and the resulting light-yellow solution was stirred at room temperature under Ar for approximately $3 \mathrm{~min}$. Then 2-iodotoluene 
(220 mg, $1.00 \mathrm{mmol}, 1.0$ equiv) and $\mathrm{Pd}_{2}\left(\mathrm{dba}_{3} \cdot \mathrm{CHCl}_{3}(26 \mathrm{mg}, 0.025 \mathrm{mmol}, 2.5 \mathrm{~mol} \%\right.$ ) were added to the solution sequentially. The flask was purged with Ar, and the reaction mixture was stirred at room temperature under $\mathrm{Ar}$ atmosphere for $24 \mathrm{~h}$. Then, the reaction mixture was passed through thin layer of silica gel (approximately $1 \mathrm{~cm}$ ) followed by a wash of EtOAc $(100 \mathrm{~mL})$. The dark-brown filtrate was added silica gel $(1 \mathrm{~g})$ and was concentrated under reduced pressure. The crude product adsorbed on silica gel was purified using flash chromatography (silica gel (45 g), hexane/EtOAc, 40/1 (500 mL), 30/1 (500 mL), 20/1 (500 mL), 10/1 (1 L), 5/1 (250 mL)), reverse phase flash chromatography (first column: reverse phase silica gel ( $80 \mathrm{~g}$ ), $\mathrm{MeOH} / \mathrm{H}_{2} \mathrm{O}$, 3/1 (500 mL), 5/1 (250 mL), second column: reverse phase silica gel $(60 \mathrm{~g}), \mathrm{MeOH} / \mathrm{H}_{2} \mathrm{O}, 3 / 1$ $(300 \mathrm{~mL}), 5 / 1(200 \mathrm{~mL}))$, and diffusion pump distillation to afford $284 \mathrm{mg}(73 \%)$ of $22 \mathrm{c}$ as a colorless, viscous liquid.

Data for 22c:

b.p.: $\quad 180^{\circ} \mathrm{C}(\mathrm{ABT})$ at $5.5 \times 10^{-5} \mathrm{mmHg}$

${ }^{1} \mathrm{H}$ NMR: $\quad\left(500 \mathrm{MHz}, \mathrm{CDCl}_{3}\right)$

7.20-7.16 (m, 3 H, HC(9), HC(10), HC(11)), 7.15-7.12 (m, 1 H, HC(12)), 6.44 (s, $1 \mathrm{H}, \mathrm{HC}(6))$ ), 4.26-4.13 (m, 2 H, $\left.\mathrm{H}_{2} \mathrm{C}\left(2^{\prime}\right)\right)$ ), 4.24 (q, $\left.2 \mathrm{H}, J=7.6, \mathrm{H}_{2} \mathrm{C}\left(2^{\prime}\right)\right), 3.56$ (s, $\left.3 \mathrm{H}, \mathrm{H}_{3} \mathrm{C}(16)\right)$, 3.47-3.39 (m, $\left.1 \mathrm{H}, \mathrm{HC}(4)\right), 3.20$ (dt, $1 \mathrm{H}, J=16.1,2.4, \mathrm{HC}(2)$ ), 3.06 (dt, $1 \mathrm{H}, J=16.1,1.5, \mathrm{HC}(2)), 2.75$ (ddd, $1 \mathrm{H}, J=13.4,8.3,1.4, \mathrm{HC}(5)$ ), 2.29 (dd, $1 \mathrm{H}, J=16.0,4.1, \mathrm{HC}(14)), 2.21$ (s, $\left.3 \mathrm{H}, \mathrm{H}_{3} \mathrm{C}(13)\right), 2.05$ (dd, $1 \mathrm{H}, J=$ 15.9, 10.4, HC(14)), 2.01 (dd, $1 \mathrm{H}, J=13.6,7.2, \mathrm{HC}(5)$ ), 1.28 (t, $3 \mathrm{H}, J=7.1$, $\left.\mathrm{H}_{3} \mathrm{C}\left(3^{\prime}\right)\right), 1.27$ (t, $\left.3 \mathrm{H}, J=7.2, \mathrm{H}_{3} \mathrm{C}\left(3^{\prime}\right)\right)$.

${ }^{13} \mathrm{C}$ NMR: $\quad\left(126 \mathrm{MHz}, \mathrm{CDCl}_{3}\right)$

$172.8(\mathrm{C}(15)), 171.8\left(\mathrm{C}\left(1^{\prime}\right)\right), 171.6\left(\mathrm{C}\left(1^{\prime}\right)\right), 143.8(\mathrm{C}(3)), 136.7(\mathrm{C}(7)), 136.1$ (C(8)), 130.0 (C(aryl)), 128.2 (C(12)), 127.2 (C(aryl)), 126.0 (C(aryl)), 123.1 (C(6)), $61.8\left(\mathrm{C}\left(2^{\prime}\right)\right), 61.8\left(\mathrm{C}\left(2^{\prime}\right)\right), 58.6(\mathrm{C}(1)), 51.6(\mathrm{C}(16)), 42.6(\mathrm{C}(2)), 40.0$ $(\mathrm{C}(5)), 37.6(\mathrm{C}(14)), 36.2(\mathrm{C}(4)), 20.1(\mathrm{C}(13)), 14.3\left(\mathrm{C}\left(3^{\prime}\right)\right), 14.2\left(\mathrm{C}\left(3^{\prime}\right)\right)$.

IR: (neat)

$2982(\mathrm{~m}), 1732$ (s), $1436(\mathrm{~m}), 1367$ (m), 1247 (s), $1188(\mathrm{~s}), 1075(\mathrm{~s}), 1024(\mathrm{~m})$, $863(\mathrm{w}), 749(\mathrm{~m})$.

LRMS: (EI):

$388\left(33.6,[\mathrm{M}]^{+}\right), 314$ (100.0), 268 (37.5), 241 (48.3), 181 (44.1), 167 (53.1), 105 
(78.7), 83 (42.3).

HRMS: $\left(\mathrm{EI},[\mathrm{M}]^{+}\right)$:

calcd.: 388.1886

found: 388.1881

Analysis: $\mathrm{C}_{22} \mathrm{H}_{29} \mathrm{O}_{6} \quad(388.45)$

calcd.: C, 68.02; H, 7.27.

found: C, 67.85; $\quad \mathrm{H}, 7.09$.

$\underline{\mathrm{R}}_{\mathrm{f}}: \quad 0.40$ (silica gel, hexane/EtOAc, 5/1, UV)

$\underline{t_{\mathrm{R}}}: \quad 2.700 \mathrm{~min}$ (Agilent Zorbax 300SB-C8, 100\% MeCN (1 mL/min)) 


\section{Results of the NOE Experiments}

\section{Alkylidenylsilanes 6-11}

Table 1 , entry 1

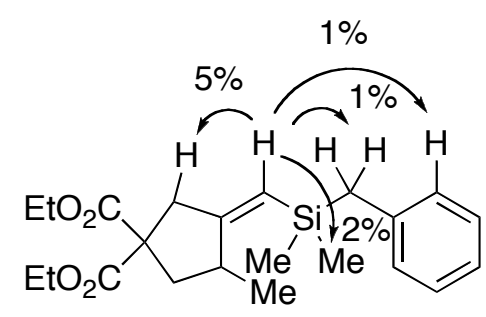

6

Table 1 , entry 2

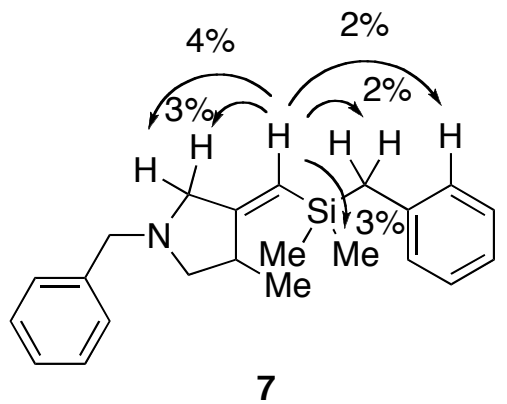

Table 1, entry 3

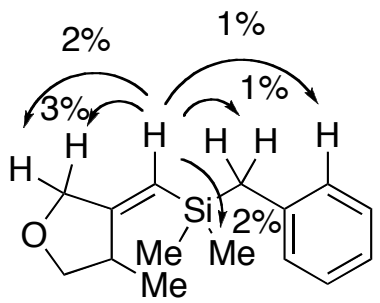

8

Table 1, entry 4

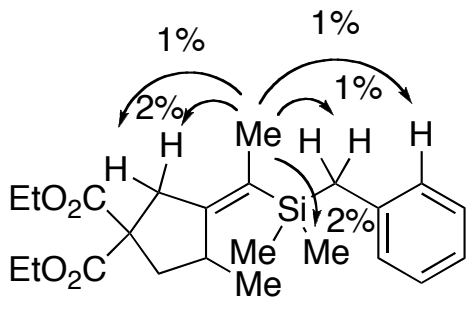

9

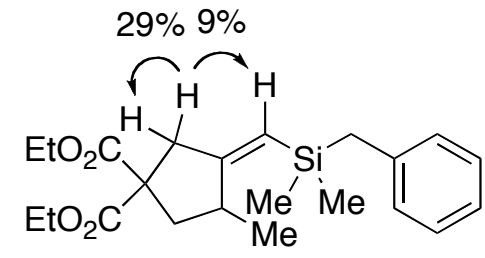

6

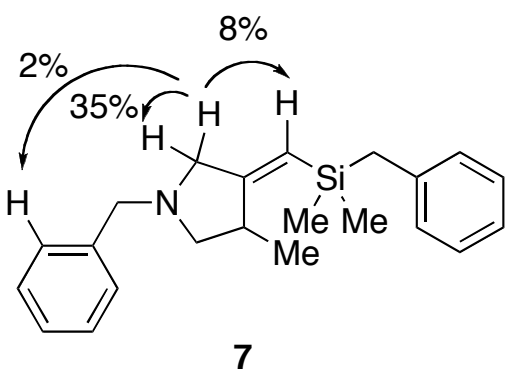

$18 \% 2 \%$

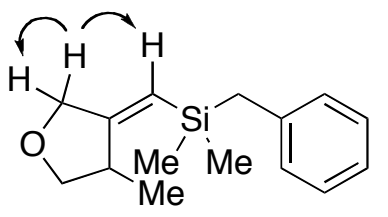

8

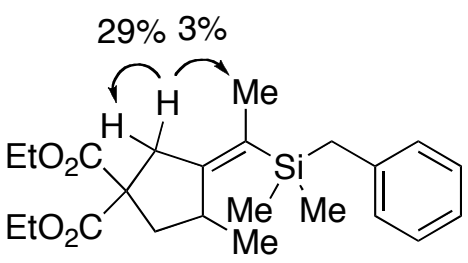

9 
Table 1, entry 5

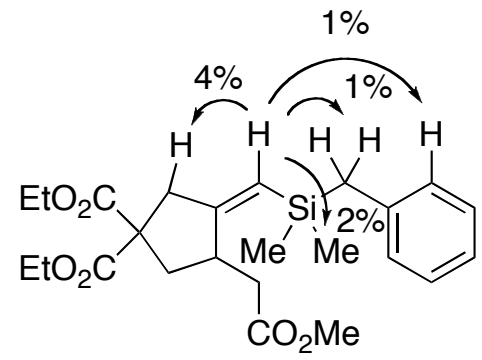

10

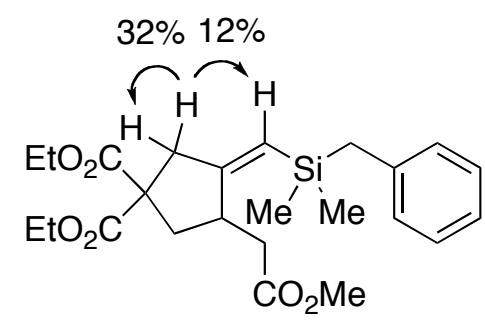

10

Table 1, entry 6

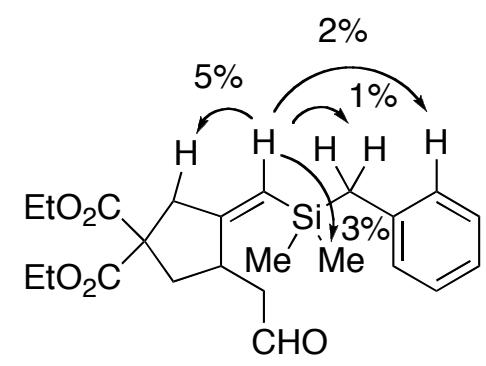

11

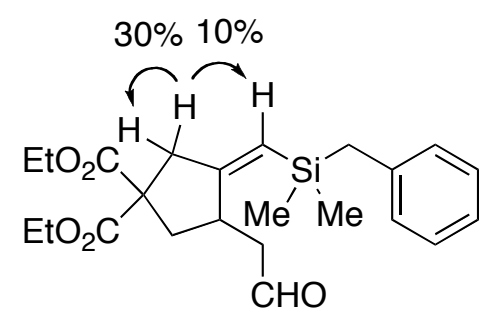

11

Benzylidinecyclopentanes 16, 19-22

Table 5, entry 1

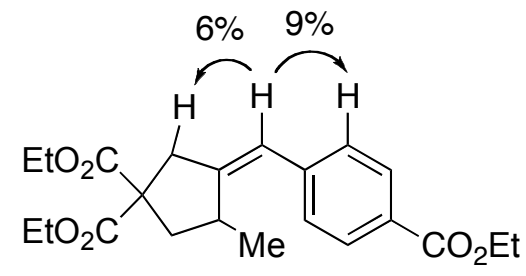

$16 a$

Table 5, entry 2<smiles>CCOC(=O)C1(C)CC(C)C(=CC2CCCCCC2)C1c1ccc(C(C)=O)cc1</smiles>

$16 b$<smiles>CCOCC1(C(=O)OCC)CC(C)/C(=C\c2ccc(C(=O)OCC)cc2)C12CCCCC2</smiles>

$16 a$

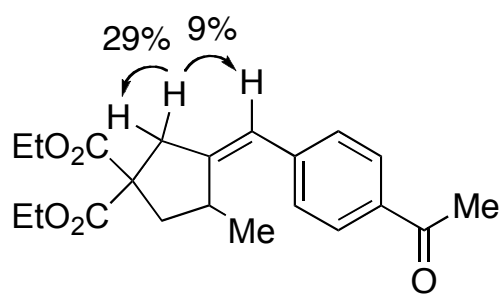

16b 
Table 5, entry 3

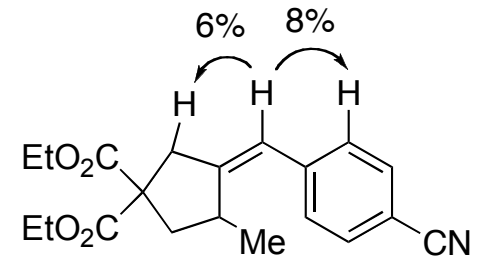

$16 c$

Table 5, entry 4

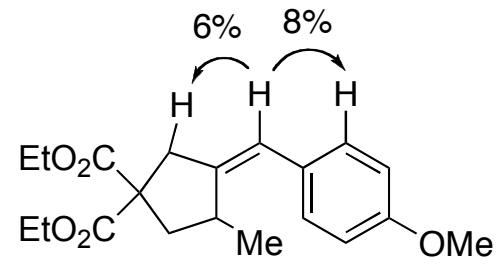

16d

Table 5, entry 5

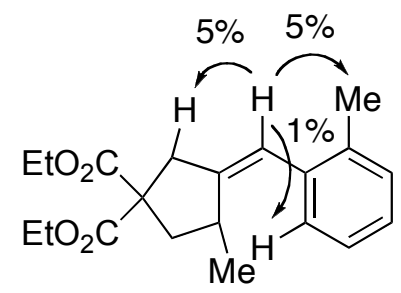

$16 e$

Table 5, entry 6

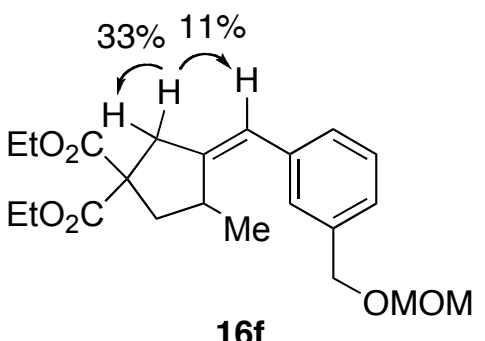

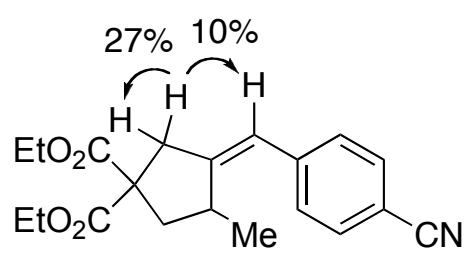

$16 c$

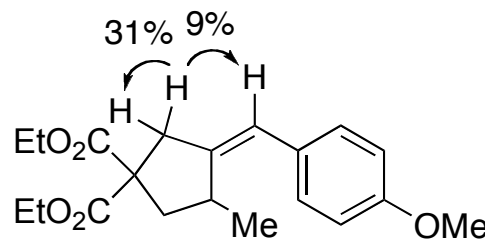

$16 d$

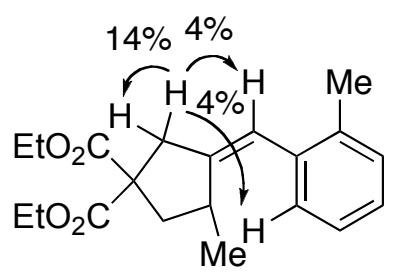

$16 e$

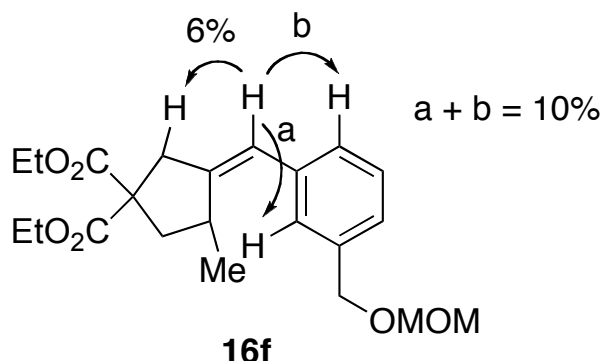


Table 5, entry 7

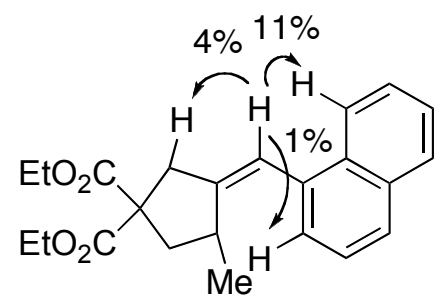

$16 \mathrm{~g}$

Table 6, entry 1

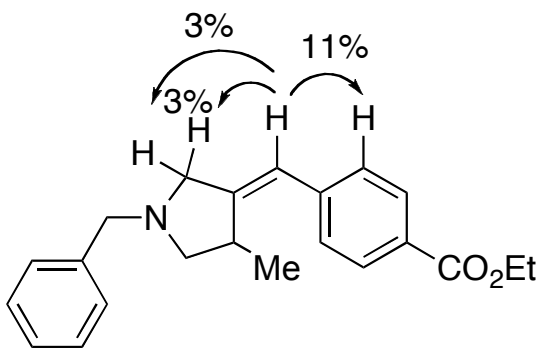

$18 a$

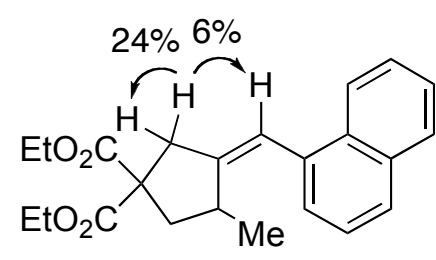

$16 \mathrm{~g}$

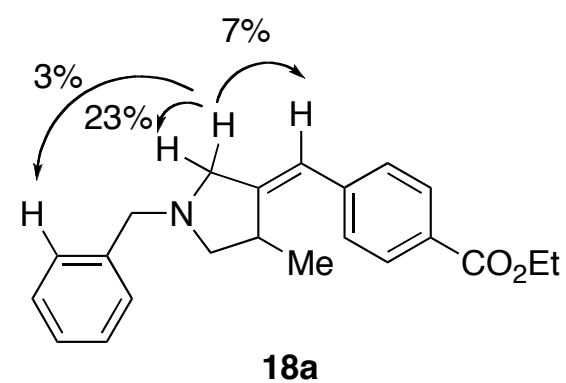

Table 6, entry 2

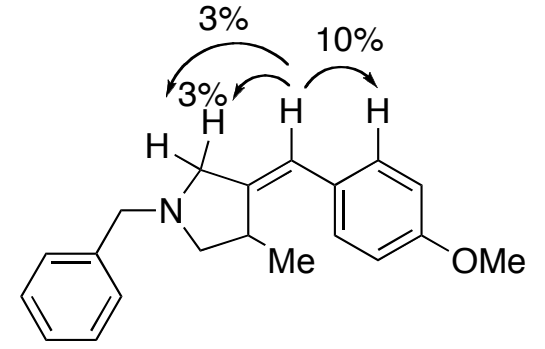

$18 b$

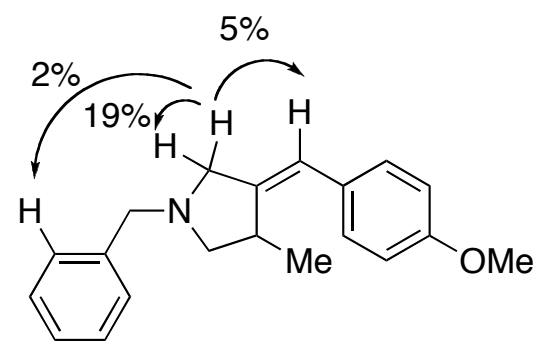

$18 b$

Table 6, entry 3
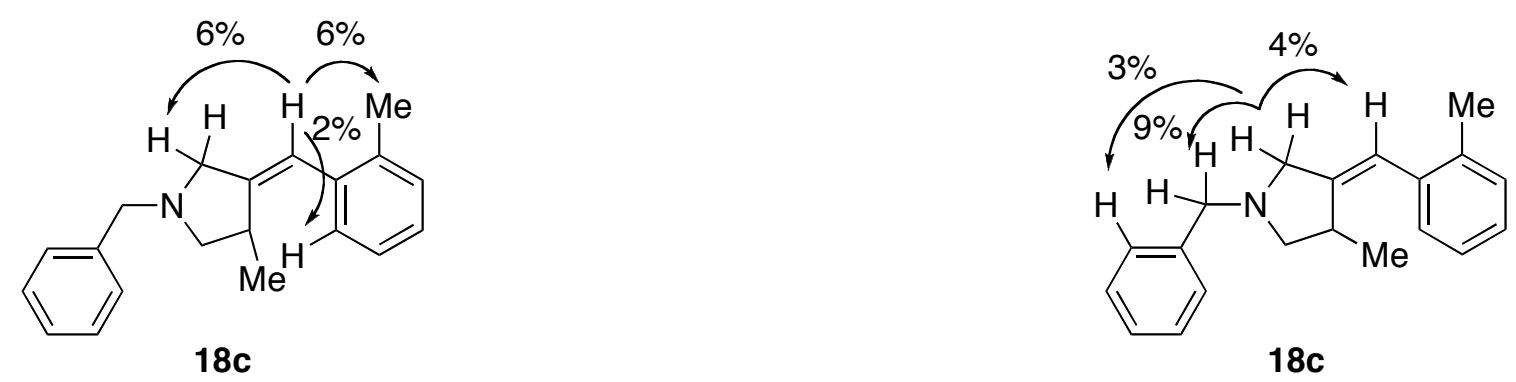
Table 6, entry 4

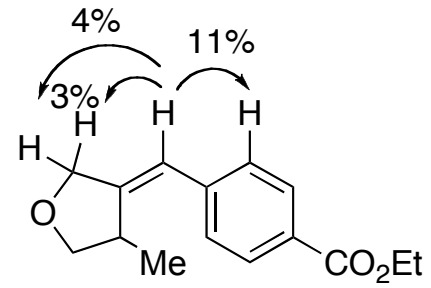

20a

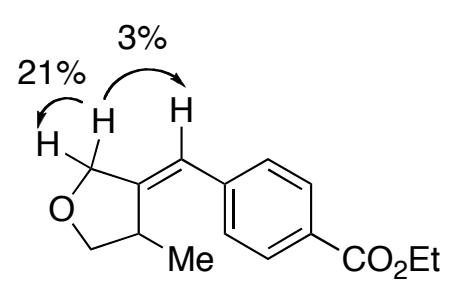

$20 a$

Table 6, entry 5

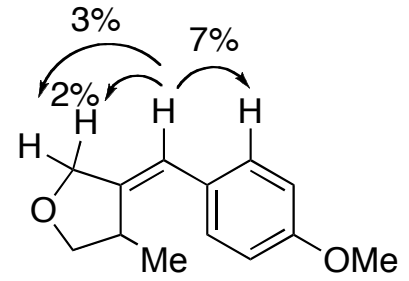

20b

Table 6 , entry 6

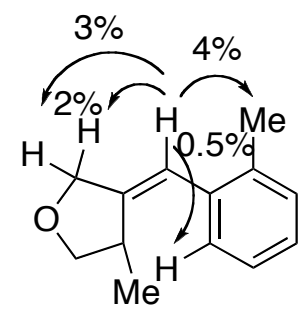

20c

Table 6 , entry 7

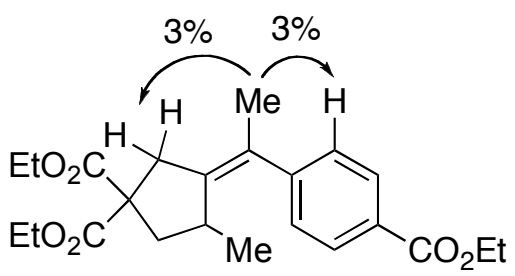

$21 a$

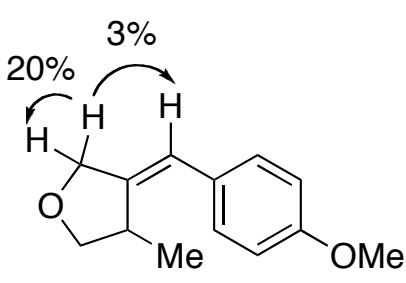

$20 b$

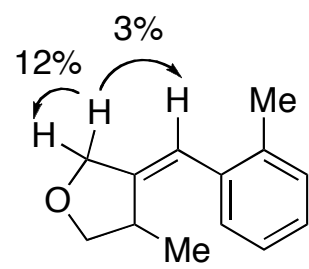

20c<smiles>CCOCC1(C)CC(C)/C(=C(/C)c2ccc(C(=O)OCC)cc2)C1CC</smiles>

$21 a$ 
Table 6 , entry 8

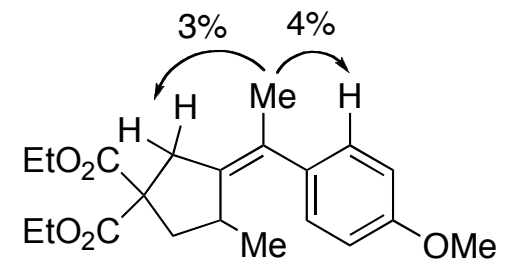

21b

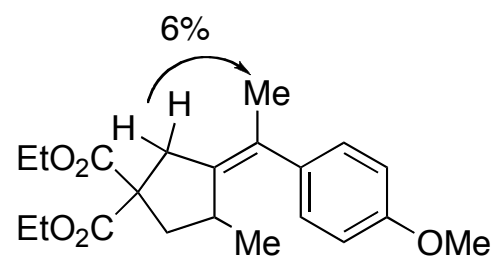

21b

Table 6, entry 9

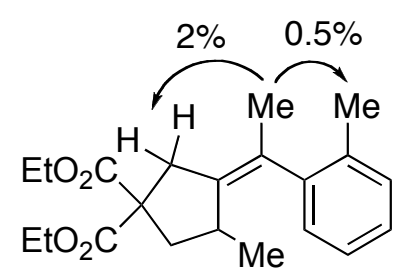

21c

Table 6 , entry 10

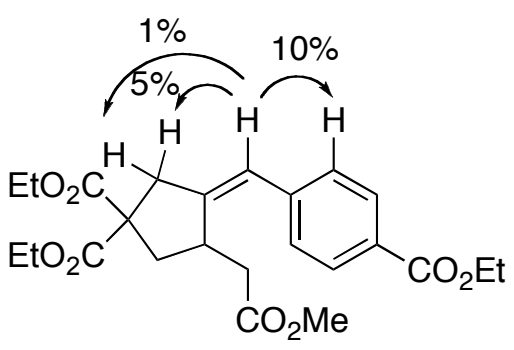

22a

Table 6, entry 11

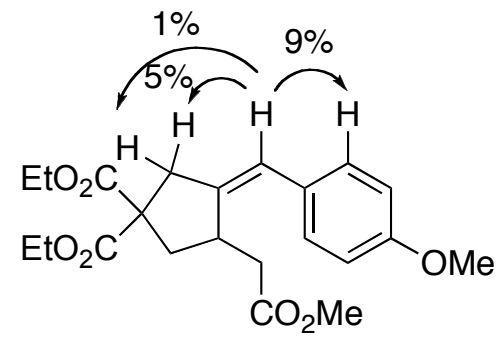

22b

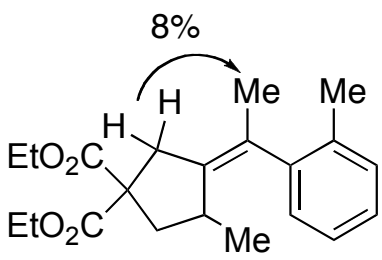

$21 c$

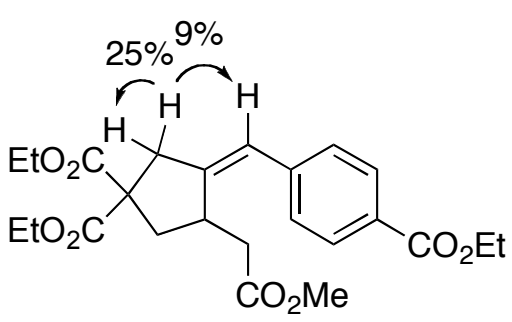

22a

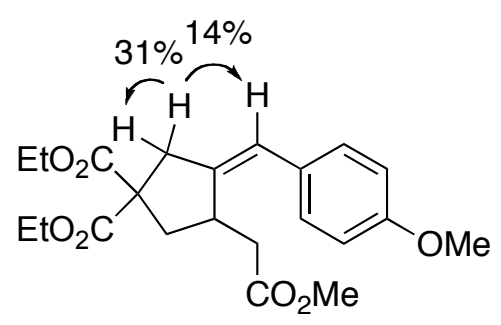

22b 
Table 6, entry 12
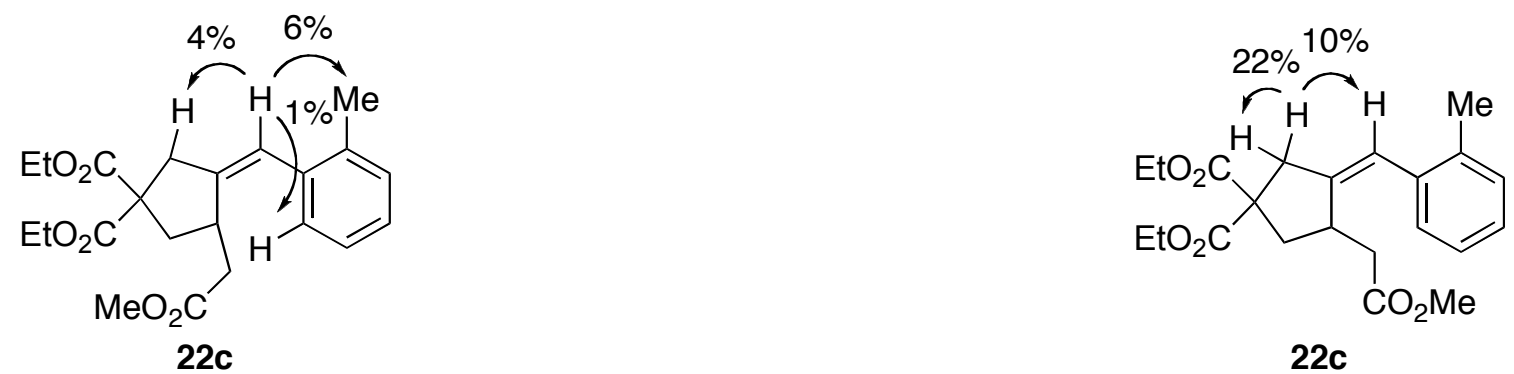

\section{Procedure of the VT NMR Experiments}

Approximately $20 \mathrm{mg}$ of 21c was dissolved in approximately $0.5 \mathrm{~mL}$ of toluene- $d_{8}$, in a 5-mm NMR tube. This sample was placed in a Varian Unity-500 NMR spectrometer. ${ }^{1} \mathrm{H}$ NMR spectra were measured at $25,40,60,80$, and $100^{\circ} \mathrm{C}$.

\section{References}

(1) Ukai, R.; Kawazura, H.; Ishii, Y.; Bonnet, J. J.; Ibers, J. A. J. Organomet. Chem. 1974, 65, 253-266.

(2) Ojima, I.; Vu, A. T.; Lee, S.-Y.; McCullagh, J. V.; Moralee, A. C.; Fujiwara, M.; Hoang, T. M. J. Am. Chem. Soc. 2002, 124, 9164-9174.

(3) Woo, L. W. L.; Smith, H. J.; Barrell, K. J.; Nicholls, P. J. J. Chem. Soc., Perkin Trans. 1 1993, 2549-2553.

(4) Houllemare, D.; Outurquin, F.; Paulmier, C. J. Chem. Soc., Perkin Trans. 1 1997, $1629-1632$. 